\title{
TRATAMENTO TÉRMICO DE MEXILHÕES Perna perna COMO FORMA DE ASSEGURAR A QUALIDADE - AVALIAÇÃO DO CRESCIMENTO DE Bacillus cereus \\ E DE Staphylococcus aureus
}

\author{
Eduardo Oliveira Salán
}

\begin{abstract}
Dissertação apresentada à Escola Superior de Agricultura "Luiz de Queiroz", Universidade de São Paulo, para obtenção do título de Mestre em Ciências, Área de Concentração: Ciência e Tecnologia de Alimentos.
\end{abstract}

P I R A C I C A B A

Estado de São Paulo - Brasil

Março - 2005 


\section{TRATAMENTO TÉRMICO DE MEXILHÕES Perna perna COMO FORMA DE ASSEGURAR A QUALIDADE - AVALIAÇÃO DO CRESCIMENTO DE Bacillus cereus E DE Staphylococcus aureus}

\section{Eduardo Oliveira Salán}

Engenheiro Agrônomo

Orientadora: Profa. Dr. a MARÍLIA OETTERER

Dissertação apresentada à Escola Superior de Agricultura "Luiz de Queiroz", Universidade de São Paulo, para obtenção do título de Mestre em Ciências, Área de Concentração: Ciência e Tecnologia de Alimentos.

PIR A C I C A B A

Estado de São Paulo - Brasil

Março - 2005 
Dados Internacionais de Catalogação na Publicação (CIP) DIVISÃO DE BIBLIOTECA E DOCUMENTAÇÃO - ESALQ/USP

Salán, Eduardo Oliveira

Tratamento térmico de mexilhões Perna perna como forma de assegurar a

qualidade - avaliação do crescimento de Bacillus Cereus e de Staphylococcus aureus I Eduardo Oliveira Salán. - - Piracicaba, 2005.

88 p. : il.

Dissertação (mestrado) - - Escola Superior de Agricultura Luiz de Queiroz, 2005. Bibliografia.

1. Análise sensorial 2. Bacillus 3. Bactéria patogênica 4. Mexilhão 5. Microbiologia de alimentos 6. Qualidade do alimento 7. Staphylococcus 8. Tratamento térmico I. Título

CDD 664.94

"Permitida a cópia total ou parcial deste documento, desde que citada a fonte - O autor" 


\title{
Dedico esta dissertação,
}

\author{
Aos meus pais, Suely e Antonio, \\ pelo amor, incentivo, paciência e \\ por estarem sempre ao meu lado, \\ a minha eterna gratidão!
}

Aos meus irmãos, Fernando e Maurício, pelo incentivo, amizade e apoio nas horas difíceis. 


\section{AGRADECIMENTOS}

À minha orientadora Dra. Marília Oetterer, pelo exemplo de profissionalismo, incentivo, amizade e orientação durante a realização desta pesquisa;

À Escola Superior de Agricultura "Luiz de Queiroz", Universidade de São Paulo, e Departamento de Agroindústria, Alimentos e Nutrição pela oportunidade de realização da pesquisa;

À Fundação de Apoio à pesquisa do Estado de São Paulo (FAPESP) pelo financiamento da pesquisa;

À CAPES pela concessão da bolsa;

A todas as entidades parceiras deste projeto: Associação dos Maricultores do Estado de São Paulo (AMESP), Instituto de Pesca (IPESCA), APTA e Prefeitura da Estância Balneária de Ubatuba; pela facilidade, e disponibilidade de matériaprima, imprescindíveis para a realização desta pesquisa, e em todo o projeto;

Ao Prof. Dr. Ernani Porto pela amizade, paciência e colaboração na elaboração das análises microbiológicas;

Ao Prof. Dr. Cláudio Rosa Gallo pela colaboração e auxílio na elaboração das análises microbiológicas; 
À Profa Dra. Marta Helena Fillet Spoto pela colaboração e auxílio na elaboração da análise sensorial;

A equipe de pesquisadores e estagiários deste projeto, Érika Fabiane Furlan, Juliana Antunes Galvão, Marcelo Maniero Ficher, Paula Porreli e Viviane Angeli Yokoyama, pelo auxílio nas coletas, e em todo desenvolvimento desta pesquisa;

Aos funcionários do Departamento de Agroindústria, Alimentos e Nutrição, especialmente às técnicas do Laboratório de Microbiologia, Rose Ocangne e Cecília Nogueira;

Às bibliotecárias Midiam Gustinelli e Beatriz Helena Giongo pelo auxílio bibliográfico prestado;

À minha amiga, Roberta Rizzo, pela amizade e pelas boas risadas.

A todos os participantes da análise sensorial;

E a todos que contribuíram direta $e$ indiretamente para a execução desta pesquisa;

Em especial à Lucimeire Pilon pelo carinho, amor, compreensão, participação, paciência, colaboração e incentivo demonstrados; 


\section{SUMÁRIO}

Página

LISTA DE FIGURAS .................................................... viii

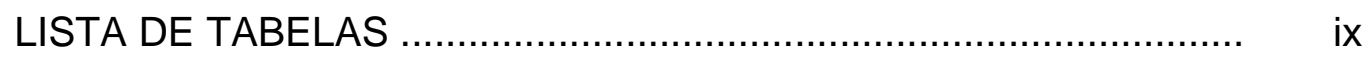

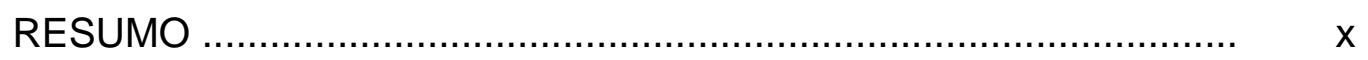

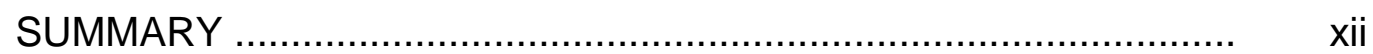

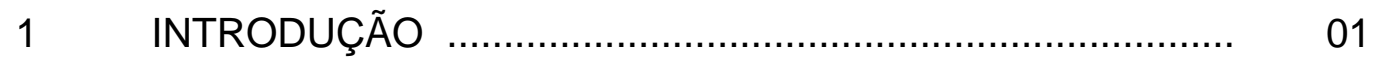

2 REVISÃO DE LITERATURA ...................................... 06

2.1 Bivalves: cultivo, produção e consumo ....................................... 06

2.2 Microrganismos relacionados ao cultivo .................................... 09

2.2.3 Microrganismos na água ........................................................... 09

2.2.4 Microrganismos da carne .......................................................... 11

2.2.5 Surtos alimentares relacionados com moluscos ...................... 13

$2.3 \quad$ Microrganismos estudados ....................................................... 14

2.3.1 Bacillus cereus ........................................................................ 14

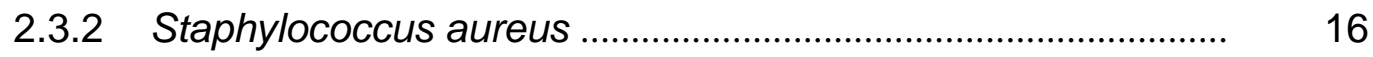

$2.4 \quad$ Beneficiamento dos mexilhões ................................................ 18

2.4.1 Tratamento térmico ...................................................................... 19

2.4 .2 Valor nutricional ................................................... 21

2.4.3 Análise sensorial ...................................................... 24

3 MATERIAL E MÉTODOS ............................................ 26

3.1 Coleta das amostras .............................................................. 26

Inóculo ............................................................................. 28 
3.2.1 Determinação da curva de crescimento ..................................... 28

3.2.2 Preparo da solução para inoculação .......................................... 29

3.3 Preparo da amostra e Inoculação ............................................... 29

3.4 Análises microbiológicas .......................................................... 30

3.4.1 Preparo das diluições ............................................................... 31

3.4.2 Contagem de Bacillus cereus ................................................. 31

3.4.3 Contagem de Staphylococcus aureus ...................................... 33

3.5 Tratamentos térmicos dos mexilhões ....................................... 33

3.6 Análise microbiológica dos mexilhões cozidos ....................... 35

3.7 Análise físico-química ............................................................... 35

3.7.1 Determinação do $\mathrm{pH}$................................................................ 35

3.7.2 Composição centesimal ............................................................ 35

3.7.3 Determinação de minerais ......................................................... 36

3.8 Rendimento e Biometria ........................................................ 36

3.9 Análise sensorial.................................................................... 37

3.10 Análises estatísticas .................................................................. 38

4 RESULTADOS E DISCUSSÃO ................................................ 39

4.1 Curva de crescimento ............................................................ 39

4.2 Análises microbiológicas - Inoculação ..................................... 40

4.3 Análises microbiológicas - Tratamento térmico ...................... 44

4.4 Análises físico-químicas e rendimento ....................................... 49

4.4.1 Biometria ............................................................................... 49

4.4.2 Composição centesimal e pH ................................................. 51

4.4.3 Minerais .............................................................................. 54

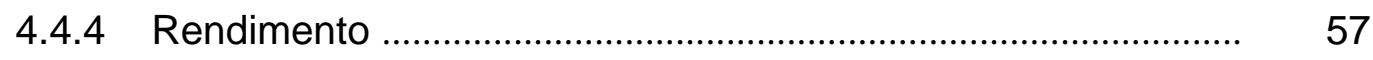

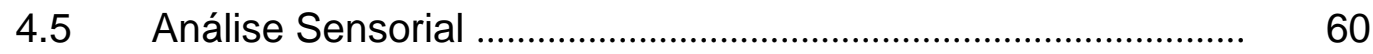

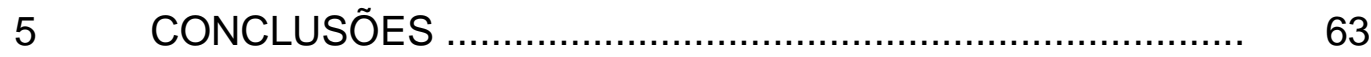

REFERÊNCIAS BIBLIOGRÁFICAS ........................................ 65

APÊNDICE .......................................................................... 86 


\section{LISTA DE FIGURAS}

Página

1 Coleta, desdobre, limpeza e transporte das amostras ................... 27

2 Procedimento de preparo dos mexilhões ..................................... 28

3 Fluxograma dos procedimentos de processamento e análises microbiológicas dos mexilhões ................................................ 30

4 Tratamento térmico de mexilhões ............................................... 34

5 Modelo de ficha de análise sensorial ........................................... 38

6 Curva de Crescimento para Bacillus cereus e Staphylococcus

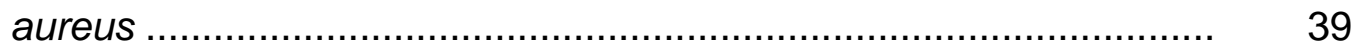

7 Crescimento do Staphylococcus aureus em mexilhões in natura e submetidos à pré-cocção, mantidos a temperatura ambiente

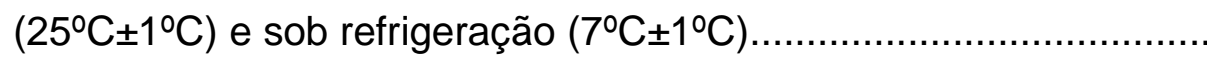

8 Crescimento de Bacillus cereus em amostras de mexilhão in natura e submetidos à pré-cocção, mantidos a temperatura ambiente $\left(25^{\circ} \mathrm{C} \pm 1^{\circ} \mathrm{C}\right)$ e sob refrigeração $\left(7^{\circ} \mathrm{C} \pm 1^{\circ} \mathrm{C}\right)$.

9 Temperaturas medidas nos termopares, ao final do tempo de cocção

10 Tratamentos térmicos para eliminação de Staphylococcus aureus e Bacillus cereus em amostras de mexilhões

11 Rendimento da parte comestível e peso total (\%), de mexilhões submetidos a diferentes tratamentos térmicos

12 Teste sensorial de ordenação entre os tratamentos térmicos 


\section{LISTA DE TABELAS}

Página

1 Crescimento de Staphylococcus aureus em amostras de mexilhão in natura e submetidos à pré-cocção, após inoculação a temperatura

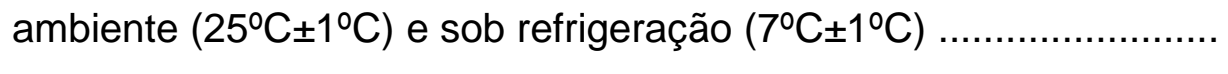

2 Crescimento de Bacillus cereus em amostras de mexilhão in natura e submetidos à pré-cocção, mantidos a temperatura ambiente $\left(25^{\circ} \mathrm{C} \pm 1^{\circ} \mathrm{C}\right)$ e sob refrigeração $\left(7^{\circ} \mathrm{C} \pm 1^{\circ} \mathrm{C}\right)$

3 Temperatura final atingida pelos 5 sensores termopares nos tratamentos térmicos realizados

4 Staphylococcus aureus (NMP $\mathrm{g}^{-1}$ ) e Bacillus cereus (NMP g $\mathrm{g}^{-1}$ ) em amostras de mexilhões, após inoculação e tratamento térmico ...... 47

5 Biometria dos mexilhões em função das coletas .......................... 50

6 Composição centesimal e pH do mexilhão submetido à cocção por diferentes tratamentos térmicos

7 Minerais em mexilhão submetido à cocção por diferentes tratamentos térmicos

8 Rendimento da parte comestível e peso total, em \%, de mexilhões submetidos a diferentes tratamentos térmicos

9 Diferença entre a soma das ordens de cada amostra submetida ao teste de ordenação 


\section{TRATAMENTO TÉRMICO DE MEXILHÕES Perna perna COMO FORMA DE ASSEGURAR A QUALIDADE - AVALIAÇÃO DO CRESCIMENTO DE Bacillus cereus E DE Staphylococcus aureus}

Autor: EDUARDO OLIVEIRA SALÁN Orientadora: Profa. ${ }^{\text {D }}{ }^{\mathrm{a}}$. MARÍLIA OETTERER

\section{RESUMO}

Os mexilhões são alimentos marinhos freqüentemente ingeridos crus, ou parcialmente cozidos, e o hábito de aferventar estes bivalves somente até que abram as valvas, é insuficiente para eliminar os microrganismos patogênicos eventualmente presentes neste molusco. Após levantamento inicial, e visando melhorar a qualidade do mexilhão Perna perna cultivado e comercializado no município de Ubatuba, SP, esta pesquisa estudou o crescimento de Staphylococcus aureus e Bacillus cereus em mexilhões in natura e pré-cozidos, e a eliminação dos mesmos por meio de tratamentos térmicos, avaliando, posteriormente, as características físico-químicas e sensoriais dos produtos. Em ambos os casos, lotes de $1 \mathrm{~kg}$ de mexilhão foram inoculados, individualmente, com cepas de $S$. aureus e $B$. cereus e mantidos, por 10 horas, a temperatura ambiente $\left(25^{\circ} \mathrm{C} \pm 1^{\circ} \mathrm{C}\right)$ e sob refrigeração $\left(7^{\circ} \mathrm{C} \pm 1^{\circ} \mathrm{C}\right)$. 
Posteriormente, foram estabelecidos seis tipos de tratamentos térmicos, sendo três sob vapor (5, 10 e 15 min) e três por imersão em água (5, 10 e 15 min), buscando estabelecer o binômio que proporcionasse a eliminação dos mesmos, e avaliando o rendimento, os aspectos físico-químicos e sensoriais. Para ambos microrganismos, ocorreu crescimento durante as 10 horas de estudo, sendo este mais evidente, nos tratamentos mantidos a temperatura ambiente. No mexilhão pré-cozido ocorreram as maiores contagens microbianas, se comparado ao mexilhão in natura. Com relação aos tratamentos térmicos, todos foram eficientes, eliminando os microrganismos da ordem de, pelo menos 2 ciclos logarítmicos, no entanto, os tratamentos térmicos por imersão em água, permitiram melhores resultados do que os tratamentos sob vapor. As análises fisico-químicas e sensoriais, não apresentaram diferença estatística entre os tratamentos térmicos estudados. Com o emprego de altas temperaturas por um determinado período, obteve-se perda de alguns minerais, como Potássio e Boro, tendo outros, não apresentado alteração com relação ao tempo de exposição ao calor. Já, quanto ao rendimento, houve diferença, em nível de 5\%, sendo os melhores rendimentos alcançados nos menores tempos de exposição ao calor e, os tratamentos por imersão, apresentaram resultados melhores que os tratamentos sob vapor. Concluiu-se que o tratamento térmico, binômio tempo-temperatura, de 10 min em água à ebulição, é suficiente para reduzir os microrganismos, permitindo a retenção dos nutrientes e um rendimento de $54,36 \%$, podendo, portanto, ser recomendado para os produtores, visando melhorar a qualidade do mexilhão, via adequação do manejo atualmente empregado. 


\section{THERMICAL TREATMENT AS A FORM TO CERTIFICATE THE QUALITY OF Perna perna MUSSEL - EVALUATION OF Bacillus cereus AND Staphylococcus aureus GROWTH}

Author: EDUARDO OLIVEIRA SALÁN Adviser: Profa. Dra. MARÍLIA OETTERER

\section{SUMMARY}

Mussels are seafood frequently ingested raw or partially cooked and the habit of boiling bivalves only to open the valves, is insufficient to eliminate several species of pathogenic bacteria. Seeking to improve the quality of the cultivated and marketed Perna perna mussel in the district of Ubatuba, SP, this research studied the microbiological growth of Staphylococcus aureus and Bacillus cereus in fresh and pre-cooked mussels, and the elimination by thermal treatments, being evaluated its physicochemical and sensorial characteristics. For such, lots of $1 \mathrm{~kg}$ of mussel was inoculated individually with strains of $S$. aureus and $B$. cereus, and maintained by 10 hours at environmental temperature $\left(25^{\circ} \mathrm{C} \pm 1^{\circ} \mathrm{C}\right)$ and under refrigeration $\left(7^{\circ} \mathrm{C} \pm 1^{\circ} \mathrm{C}\right)$. Six thermal treatments were established, 3 in steam (5, 10 and $15 \mathrm{~min}$ ) and 3 in boiling water (5, 10 and $15 \mathrm{~min}$ ), being looked in the elimination of $B$. cereus and $S$. aureus, and also evaluating the performance, and physical-chemical and sensorial aspects. Microbiological growth was verified after 10 hours for both 
microorganisms, and this being more evident in the treatments maintained at environmental temperature. Pre-cooked mussel obtained the largest microbial developments, if compared to fresh mussels. About the thermal treatments, everyone was efficient, eliminating at least 2 logarithmic cycles, however, thermal treatments in boiling water obtained better results than the steam treatments. The physical-chemical and sensorial analyses, didn't present statistical difference among the thermal treatments studied. Use of high temperatures for a determinate period, obtained lost in some minerals, like potassium and boron, and others minerals not presented alteration in relation to the heat time exposure. Already in the performance, it was obtained statistical difference, being the best performances reached in the smallest times of heat exposition, and the treatments in boiling water presented better results than the steam treatments. The thermal treatment, binomial time-temperature, of $10 \mathrm{~min}$ in boiling water, is enough to reduce the microorganisms, allowing the retention of the nutrients and performance of $54.36 \%$, could be recommended for the producers seeking to improve the traditional handling. 


\section{INTRODUÇÃO}

A oferta mundial de pescado para a alimentação humana aumentou de 27,6 milhões de toneladas, em 1961, para mais de 93 milhões de toneladas até o final do século 20. O consumo médio aparente aumentou, de cerca de, $9 \mathrm{~kg}$ per capita/ano, no começo dos anos 60, para cerca de, $16 \mathrm{~kg}$ em 1997, com tendência de aumento (FAO, 2004a).

Ao contrário da pesca extrativa, a aqüicultura vem crescendo rapidamente nas últimas décadas, com média de $10 \%$ de crescimento ao ano desde 1984 (FAO, 2004b), sendo o cultivo de moluscos responsável por 24\% de toda produção aqüícola mundial, e os mexilhões, representando cerca de 13,3\% da produção de moluscos cultivados (Ostrensky et al., 2000; Streit et al., 2002).

No Brasil, a maricultura está representada, basicamente, pelo cultivo de crustáceos e moluscos. A produção brasileira de moluscos está em torno de 6.690t, o que corresponde a $48 \%$ de todo o mexilhão produzido na América Latina (Subasinghe et al., 2001). Segundo Borghetti \& Ostrensky (2000), os moluscos produzidos no Brasil são o mexilhão Perna perna, duas espécies de ostra e uma de vieira.

A mitilicultura é uma das atividades mais produtivas da aqüicultura alcançando, até, $30 \mathrm{t}$ de carne por ha/ano, o que representa a maior cifra obtida com modalidade de criação não sujeita a alimentação artificial. Além de diversos aspectos biológicos favoráveis, outros fatores como o baixo custo das instalações, facilidade de manejo e de localização dos cultivos no mar contribuíram para a expansão mundial dessa atividade (Gelli et al., 1998). 
No estado de Santa Catarina, através de parcerias entre os órgãos federais, estaduais e municipais, iniciou-se em 1998 projetos de capacitação e transferência de tecnologia de criação de mexilhões aos pescadores artesanais e atualmente, o Estado destaca-se como o maior produtor de mexilhões de cultivo no Brasil. Em 1998 - 1999, a produção foi de 8500 t, envolvendo cerca de 1000 famílias de pescadores gerando ainda, empregos diretos e indiretos dentro da cadeia produtiva. A infra-estrutura do Estado de Santa Catarina, com depuradoras comunitárias e unidades de beneficiamento monitoradas pela Universidade Federal de Santa Catarina tem permitido a colocação de mexilhões certificados congelados no mercado do Estado de São Paulo e a estimativa é de que a região deverá produzir 20 mil t/ano proveniente do cultivo de pequenos produtores (Beirão et al., 2000).

Segundo informações da AMESP - Associação dos Maricultores do Estado de São Paulo, a produção de mexilhões no Litoral Norte - é de 100 t/ano. No município de Ubatuba, SP, desenvolveu-se, com certa facilidade a atividade de criação de mexilhões, através de repasse de tecnologia gerada pelos técnicos da Agência Paulista de Tecnologia do Agronegócio (APTA) da Secretaria da Agricultura. No entanto, a atividade está envolvida em inúmeros problemas organizacionais, havendo produtores com dificuldades em obter financiamentos devido a falta de registro e, conseqüente, fiscalização, e ainda, pela impossibilidade de transportar legalmente o produto, o que se constitui em risco à saúde (Assumpção, 1999).

Porém, a contaminação de águas costeiras pode ameaçar seu uso potencial para o cultivo de moluscos bivalves que, sendo organismos filtradores, têm capacidade de concentrar e acumular altas densidades de bactérias, protozoários e vírus patogênicos, além de metais e outros compostos químicos tóxicos e toxinas provenientes de certos microrganismos (Rodrigues-Ariza et al., 1992; Rodrigues, 1998).

Marques \& Pereira (1989), efetuaram um levantamento e dimensionamento preliminares das áreas mais favoráveis à prática da 


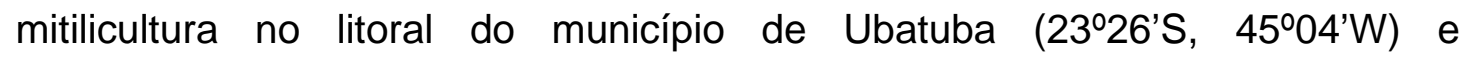
classificaram as áreas utilizando critérios prioritários para a ocupação. As áreas de cultivo foram então classificadas como: Área de ocupação primária, que apresenta condições bastante favoráveis ao cultivo; Área de ocupação secundária, embora favorável apresenta alguns inconvenientes, tais como: difícil acesso e ocasional turbulência das águas; Área de ocupação terciária, embora a mitilicultura seja viável poderá conflitar com outras atividades, como navegação, pesca e recreação.

É nesse contexto que se estabeleceu uma parceria, através de um programa de políticas públicas da FAPESP, entre a Universidade de São Paulo - ESALQ e a Prefeitura Municipal da Estância Balneária de Ubatuba, a fim de estabelecer as etapas de levantamento da situação, diagnosticando os pontos críticos e sugerindo os caminhos para tornar viável a comercialização do pescado, com valor agregado dirigido ao produtor, e que possa fixá-lo em uma atividade mais sólida e rentável. O presente trabalho encontra-se inserido dentro deste programa, intitulado de "Diagnóstico e intervenções emergentes para viabilizar a comercialização e o beneficiamento do pescado e derivadosmexilhões, no Litoral Norte de São Paulo". A primeira fase do projeto consistiu no diagnóstico da situação de produção e comercialização de mexilhões, bem como da avaliação da qualidade da água de cultivo e do produto em pontos de coleta eleitos para a amostragem, no período de 2002 - 2003 (Oetterer, 2003).

Inicialmente foram escolhidos 3 pontos de coleta onde a atividade já havia sido implantada, de acordo com o levantamento de Marques \& Pereira (1989), e que caracterizavam-se por serem bem distintos, sendo eles, a praia da Barra Seca (2325'26.8'S, 4502'56,9"W), praia do Engenho da Almada (2321'06.2"S, 44'53'11.4"W) e o Costão da Praia do Cedro (233'45.5'"S, 4509'32.9”W), todos classificados como área de ocupação primária. Dos três pontos, foram coletadas amostras de água e mexilhão, no período de Novembro de 2002 a Março de 2003, e realizadas análises microbiológicas e físico-químicas. 
As análises microbiológicas mostraram que a maioria das amostras de mexilhões analisada apresentou-se dentro dos padrões estabelecidos na legislação para pescado. As maiores contagens ocorreram nos mexilhões provenientes de áreas densamente povoadas e mais próximas da saída de efluentes (Barra Seca). Todas as amostras de água tiveram um resultado negativo para Salmonella, o que não ocorreu com os mexilhões, havendo uma amostra positiva no mês de março na praia da Barra Seca (Galvão, 2004).

Outra constatação mostrou que todas as amostras de mexilhão apresentaram contagens microbianas superiores as encontrados na água, fato este que concorda com a afirmação de que os bivalves são citados como amostradores biológicos e bioacumuladores da matéria e/ou substâncias préexistentes na água (Galvão, 2004).

Tanto Staphylococcus aureus como Bacillus cereus foram encontrados no mexilhão em contagens baixas. Todavia, concluiu-se que há um risco potencial com relação a $S$. aureus e $B$. cereus, uma vez que estes são patogênicos, e pela maneira que estes são comercializados, tornando-se um risco para a saúde do consumidor.

As análises físico-quimicas realizadas no mexilhão por Furlan (2004), atestaram a boa qualidade da matéria-prima, possuindo um bom rendimento, e apresentando-se dentro dos padrões da legislação vigente para pescado. A utilização da refrigeração imediata dos mexilhões após a coleta, aumentou a vida útil do mexilhão em 5 dias, o que possibilita a sua comercialização por um tempo maior, se tornado imprescindível uma manipulação adequada.

Uma vez definida a boa qualidade dos mexilhões para a comercialização, conforme exigências da legislação, elegeu-se um ponto, o do Costão da Praia do Cedro, por possuir uma menor variação da produção ao longo do ano e ser de acesso mais fácil do que os demais (Furlan et al., 2003a; Furlan et al., 2003b).

Como objetivo, nesta etapa da pesquisa, pretendeu-se verificar o crescimento de Bacillus cereus e Staphylococcus aureus em amostras de 
mexilhões in natura e pré-cozidas, armazenadas por um período de 10 horas a temperatura ambiente $\left(25^{\circ} \mathrm{C} \pm 1^{\circ} \mathrm{C}\right)$ e sob refrigeração $\left(7^{\circ} \mathrm{C} \pm 1^{\circ} \mathrm{C}\right)$; estabelecer o binômio tempo-temperatura para a eliminação destes microrganismos, através de 6 diferentes tratamentos térmicos, e o efeito destes tratamentos nas características físico-químicas e sensoriais deste molusco. 


\section{REVISÃO DE LITERATURA}

\subsection{Bivalves: cultivo, produção e consumo}

No início do século XIII, segundo uma conhecida versão, um barco tripulado por três irlandeses e comandado por Patrick Walton, naufragou em uma região deserta na Ponta d'Éscale, próximo a Rochele, na Bretanha francesa, tendo sobrevivido somente o comandante. Durante o período em que ali permaneceu abrigado, ele sobreviveu à custa da caça e da pesca, utilizando para tal, entre outras armadilhas, uma série de postes de madeira fincados na praia, entrelaçados com pedaços de redes de pesca e cordas, na tentativa de capturar aves marinhas. Nas estacas e redes que ficavam submersas durante as marés altas, ele observou a fixação de uma grande quantidade de mexilhões dos quais também passou a se alimentar. Mais tarde, já resgatado, divulgou sua descoberta por outras regiões da França e na Grã-Bretanha, dando início assim à atividade da criação de mexilhões (Marques, 1998).

O cultivo de moluscos foi iniciado, pelos japoneses, em 2000 a.C., e pelos romanos, em 100 a.C. (José, 1996). Como atividade econômica produtiva, a mitilicultura, estabeleceu-se na Espanha no início da década de 40, e desde então, os cultivos se espalharam comercialmente pelos países da Europa, Ásia e América do Sul (Andréu, 1976).

No Brasil, as primeiras pesquisas sobre mitilicultura foram realizadas pelo Instituto de Biociências da USP, na década de 60, que visavam o estudo dos mexilhões nos estuários de Santos e São Sebastião. Paralelamente, a Superintendência do Desenvolvimento do Nordeste (SUDENE) iniciou 
investigações sobre a espécie Mytella falcata, na Lagoa Mundaú, em Maceió (Ferreira \& Magalhães, 1996).

Em meados da década de 70, a Secretaria de Agricultura do Estado de São Paulo, através do Instituto de Pesca, iniciou em Ubatuba um programa de pesquisas sobre ecologia e cultivo de mexilhões, que resultou no aprimoramento das balsas de cultivo que haviam sido desenvolvidas pelo Instituto de Pesquisas da Marinha em Arraial do Cabo - RJ, e também no repasse das técnicas a criadores particulares e outras instituições de pesquisa e extensão. Porém, apesar das excelentes condições climáticas e ambientais disponíveis para o desenvolvimento da mitilicultura, apenas a partir dos anos 90 é que essa atividade despontou comercialmente (Marques, 1998).

Segundo Ostini \& Gelli (s/d) há vários métodos de cultivo de mexilhões. O cultivo em estaca é muito utilizado na França e apresenta a vantagem de não expor os bivalves aos predadores do fundo; a desvantagem é a exposição ao ar na maré baixa, reduzindo o tempo hábil de alimentação. O cultivo sobre o fundo é uma técnica muito utilizada na Holanda e consiste no transporte de mexilhões jovens para os locais de cultivo, geralmente em águas calmas e rasas; a vantagem deste sistema está no fato de que o marisco permanece todo o tempo submerso, alimentando-se continuamente, mas tem como maior desvantagem o contato deste com o lodo e conseqüente presença de resíduos minerais no intestino, depreciando o produto final. Para a implantação do cultivo suspenso, muitos aspectos devem ser levados em consideração, embora seja uma técnica muito utilizada no Mediterrâneo; com a vantagem de apresentar baixo custo de implantação e manutenção.

A produção brasileira de bivalves está centrada nos estados do Rio de Janeiro, São Paulo e Santa Catarina devido principalmente, às características ambientais propícias ao desenvolvimento desses moluscos, os quais necessitam de águas de temperaturas amenas e ricas em nutrientes (Beirão et al., 2000). 
Atualmente, a produção de mexilhão do Litoral Norte é de aproximadamente 100 ton/ano e, como todas as iniciativas de criação de moluscos bivalves no país, é caracteristicamente clandestina, no que se refere à legalização de uso da área. Isso ocorre porque a legislação pertinente Decreto 2869 - permanece com suas normas complementares ainda não aprovadas, o que pode dificultar a aquisição do Registro do Aquicultor por parte dos criadores e, conseqüentemente, de financiamentos e garantias previstas no corpo do Decreto (Pereira et al., 2003).

Ao lado desta problemática deve-se considerar que, no país, por razões culturais e sócio-econômicas o consumo de pescado ainda é pouco expressivo; nos últimos anos, todavia, tem-se observado uma mudança no perfil nutricional da população e a oferta de pescado de qualidade no mercado interno, pode direcionar o consumo, em especial pela oferta de novas formas de apresentação deste alimento perecível (Germano et al., 1998).

Cabe salientar que, no Brasil, o universo de consumidores de pescado, divide-se em dois pólos distintos: a população de baixa renda, que habita regiões ribeirinhas ou litorâneas que têm no pescado a única fonte de proteínas, e a de alta renda que deverá ter no pescado um alimento alternativo, que permitirá manter uma dieta rica em nutrientes e com baixos índices calóricos e portanto, melhor para a saúde (Silva, 1969 citado por Espínola \& Dias 1980; Germano et al., 1998).

O comportamento do consumidor é influenciado por variáveis sóciodemográfico-culturais, variáveis psicológicas (estilo de vida, motivação) e por situação de compra. Com relação à freqüência do consumo, 39.31\% dos paulistanos afirmam consumir moluscos poucas vezes ao ano e $26.21 \%$ apenas nos meses do verão. Apesar do consumidor preferir em $52.08 \%$ das vezes consumir o produto em casa, observa-se um valor relevante para o consumo em restaurantes de (34.38\%) (Barni et al, 2002). 


\subsection{Microrganismos relacionados ao cultivo}

\subsubsection{Microrganismos na água}

A qualidade dos moluscos bivalves, especialmente ostras e mexilhões, está diretamente relacionada com a qualidade do ambiente onde estas espécies são cultivadas ou extraídas (Wood, 1979; Jay, 1994). Sendo assim, se as águas de cultivo ou extração estão contaminadas, os moluscos provenientes desses locais também poderão apresentar bactérias patogênicas ou vírus capazes de provocar riscos à saúde (ICMSF, 1983).

A água atua por conseqüência de sua contaminação como importante veículo de inúmeras doenças, seja em decorrência de excretos humanos ou de outros animais, seja pela presença de substâncias químicas nocivas à saúde humana. A avaliação microbiológica precisa ser realizada periodicamente para que se tenha controle das doenças de transmissão hídrica (Cavalcante et al. 1998; Guilherme et al., 2000).

A qualidade sanitária do ambiente aquático, onde os bivalves são capturados, responde diretamente pelos problemas de Saúde Pública que podem gerar quando consumidos, principalmente se ingeridos in natura (Santos, 1982). Os bivalves, após a coleta, apresentam em média $10^{3}-10^{5}$ bactérias $\mathrm{g}^{-1}$. Estes níveis normalmente são 1 a 2 unidades logarítmicas maiores que os números encontrados na água na qual estes foram colhidos (Vasconcelos, 1969; citado por Cook, 1991).

A principal dificuldade do monitoramento da qualidade da água de um determinado local, é o estabelecimento de indicadores adequados e a definição dos critérios a serem adotados para esta avaliação. Nesse sentido, procura-se relacionar a presença de indicadores de poluição fecal no ambiente aquático e o risco potencial de se contrair doenças infecciosas por meio de sua utilização para recreação (Companhia de Tecnologia de Saneamento Ambiental CETESB, 2003). 
Vários microrganismos, principalmente bactérias da família Enterobacteriaceae, como os coliformes totais, coliformes fecais e Escherichia coli, têm sido utilizados como indicadores da qualidade sanitária das águas de cultivo e dos moluscos bivalves (Martinez-Manzanares et al., 1991). A pesquisa de coliformes fecais e Escherichia coli nos alimentos fornece, com maior segurança, informações sobre suas condições higiênico-sanitárias e são a melhor indicação da eventual presença de enteropatógenos (Franco \& Landgraf, 1996).

Segundo Hagler \& Hagler (1988), os coliformes têm pouca tolerância à salinidade das águas do mar, portanto, sua detecção nesse ambiente denota uma descarga constante de matéria fecal. A enumeração de coliformes totais em água é menos representativa como indicação de contaminação fecal que a enumeração de coliformes termotolerantes ou Escherichia coli, no entanto, sua enumeração é muito utilizada em indústrias alimentícias, indicando poluição pré-sanitização, contaminação pós-sanitização ou pós-processo, evidenciando práticas de higiene e sanitização aquém dos padrões requeridos para o processamento de alimentos (Pádua, 2003).

Por esse motivo, o Clostridium perfringens têm sido utilizado como indicador de contaminação fecal em água, pois sua incidência no meio aquático está constantemente associada a dejetos humanos, sendo sua presença comum em fezes, esgoto e águas poluídas. Como são esporogênicos, os esporos apresentam excepcional longevidade em água, em função da grande resistência aos desinfetantes e outras condições desfavoráveis do meio ambiente (Silva et al., 2000).

A contagem padrão de bactérias aeróbias heterotróficas mesófilas é considerada a técnica que melhor estima a densidade de bactérias contaminantes em águas não potáveis. A importância da avaliação do grau de poluição dessas águas utilizando a contagem padrão de bactérias, está relacionada à determinação da fonte poluidora, além de reforçar os padrões de 
qualidade da água e de traçar a sobrevivência de microrganismos (APHA, 1992).

O grupo de estreptococos fecais ocorre em grande quantidade nas fezes humanas e de outros animais e tem o trato intestinal como habitat natural. Os estreptococos fecais normalmente não ocorrem em águas e solos virgens ou não poluídos, sendo as raras ocorrências relacionadas diretamente a animais de vida selvagem ou à drenagem do solo por enxurradas. Podem persistir por longo tempo em águas de irrigação, com alto teor eletrolítico, porém não se multiplicam nas águas poluídas, sendo sua presença uma indicação de contaminação fecal recente (Silva et al., 2000).

Mendes et al (2002), em estudos realizados durante o ano de 1999, relataram que o índice de contaminação da água de cultivo é dependente de alterações sazonais. Os autores observaram que nos meses de estio (verão) o NMP de coliformes e de vibrios foi significativamente reduzidos, provavelmente devido ao aumento de salinidade, em conseqüência da maior evaporação.

No Brasil, o Conselho Nacional do Meio Ambiente (CONAMA), órgão que estabelece a classificação e normaliza os parâmetros de qualidade da água, segundo o seu uso preponderante, determina que a água salobra ou salina destinada à criação extensiva ou intensiva de espécies destinadas à alimentação humana e que serão ingeridas cruas, apresentem bactérias coliformes fecais inferior a 14 NMP $100 \mathrm{~mL}^{-1}$, com não mais de $10 \%$ das amostras excedendo 43 coliformes $100 \mathrm{~mL}^{-1}$ (Brasil, 1986).

\subsubsection{Microrganismos da carne}

A classe bivalva é de grande interesse para os ecologistas uma vez que é, provavelmente, a maior acumuladora de poluentes do meio ambiente. Esse fato tem sido objeto de estudos de avaliação de contaminação ambiental através da presença de bactérias e metais pesados em bivalves. Com o incremento da mitilicultura os riscos sanitários causados pelo consumo de 
mexilhões têm aumentado no que se refere à presença de metais pesados, fitoplancton e microrganismos (Espínola \& Dias, 1980).

Devido à sua distribuição na costa marítima e estuário, os moluscos estão por inúmeras vezes sujeitos à poluição por esgoto, principalmente nas proximidades de grandes centros urbanos. O principal perigo associado à poluição é a presença de bactérias e vírus patogênicos, o que se transforma em problema de Saúde Pública, abalando o prestígio desses alimentos junto à população; agravando o problema, está o consumo dos moluscos in natura ou, levemente cozidos (Beirão et al., 2000).

Segundo Martins (1983) sob o ponto de vista sanitário a pesquisa de Salmonella e víbrios em moluscos bivalves, constitui em aspecto importante da Saúde Pública, pois esses microrganismos tem sido freqüentemente relacionado com a gastroenterites e toxinfecções, em populações que os consomem crus ou mal cozidos (Bean \& Griffin, 1990; Jakabi et al., 2000; Huss et al., 2000).

Os víbrios fazem parte da microflora natural de estuários e águas marinhas podendo se acumular nos tecidos dos bivalves durante sua alimentação. A maioria dos víbrios apresenta-se em concentrações significativas e pode persistir na água por um longo tempo quando associada com os organismos aquáticos, como o pescado e o plâncton (Langraf et al., 1996; Mascarenhas et al., 1999; Maugeri et al. 2000). Ostras, mariscos e caranguejos são os veículos naturais do $V$. cholerae devido às suas características filtradoras, que conduzem à concentração de solutos e ao acúmulo de microorganismos (Lederer, 1991; Germano et al., 1993).

Segundo Laloo et al. (2000), em estudos realizados em Trinidad Tobago a respeito da qualidade bacteriológica de ostras in natura comercializadas na região, havia $57,5 \%$ delas na faixa das que excederam o padrão recomendado pelo ICMF - International Comission on Microbiological Specifications for Foods, de 5,0 $\times 10^{5} \mathrm{UFC}^{-1}$ de aeróbios totais. 
A legislação brasileira, através da Portaria $n^{\circ} 451 / 97$ do Ministério da Saúde, estabelece que a carne de moluscos "in natura" está apta para o consumo humano quando no produto o NMP de coliformes fecais não ultrapassar o limite de $100 \mathrm{~g}^{-1}$; Salmonella sp. estiver ausente em $25 \mathrm{~g}$, e a contagem em Unidades Formadoras de Colônias - UFC, de Staphylococcus aureus não exceder $10^{3} \mathrm{~g}^{-1}$. Para pescado pré-cozido, são aplicados os mesmos limites microbiológicos estabelecidos para o in natura (Brasil, 1997).

Em levantamento prévio ao presente trabalho, relatado por Galvão (2004), observou-se à presença de várias espécies de microrganismos nos mexilhões, tais como Bacillus cereus, Clostridium Sulfito Redutores, Clostridium perfringens, Staphylococcus aureus e Enterococcus.

\subsubsection{Surtos alimentares relacionados com moluscos}

O consumo de moluscos, conforme registros em literatura especializada, é responsável por inúmeros surtos epidêmicos e responde diretamente pelos problemas de saúde pública ocasionados, principalmente, quando os moluscos são ingeridos in natura e a qualidade sanitária do ambiente aquático onde eles são capturados está comprometida (José, 1996).

A maioria dos surtos alimentares documentados, envolvendo pescado marinho nos Estados Unidos, está relacionada com o consumo de moluscos bivalves. Esta incidência se deve à biologia do animal, à qualidade da água na qual este se encontra, às técnicas de manipulação pós captura e ao fato de que estes alimentos, freqüentemente, são consumidos in natura (Cook, 1991).

A importância dos frutos do mar como veículos de toxinfecções está condicionada a fatores como a dieta da população consumidora e o modo tradicional de preparo do alimento. Assim, a proporção de surtos alimentares envolvendo pescado é significativamente mais alta no Japão devido ao alto consumo de pescado in natura quando comparado a outros países como o Canadá e Estados Unidos (Huss et al., 2000). 
Do total de surtos alimentares relatados nos Estados Unidos no período de 1988 - 1992, 35\% foram causados por bactérias (Clostridium botulinum, Escherichia coli, Salmonella, Staphylococcus, Vibrio spp. e Bacillus cereus) através dos moluscos contaminados e $12 \%$ através de peixes.

Segundo Espínola \& Dias (1980), 47\% dos surtos alimentares, tendo moluscos como vetores, são causados por microrganismos de etiologia desconhecida, como hepatites não especificadas e certos tipos de Vibrios ( $V$. parahaemolyticus, V. vulnificus, V. cholerae), representando um risco ainda maior para pessoas que consomem bivalves in natura. No caso do $V$. parahaemolitycus, este microrganismo é responsável por uma elevação de 20\%, nos casos documentados, de intoxicação alimentar no Japão.

\subsection{Microrganismos estudados}

\subsubsection{Bacillus cereus}

O Bacillus cereus é um bacilo, com dimensões de 3 - $5 \mu \mathrm{m}$ de comprimento e $1 \mu \mathrm{m}$ de largura, é Gram-positivo, anaeróbico facultativo e esporulado. Os esporos, são menos termoresistentes que os do $C$. perfringens e são destruídos a $100^{\circ} \mathrm{C}$ por 5 - 30 min Aproximadamente $80 \%$ das cepas produzem enterotoxina que é excretada durante a fase logarítmica (Hayes, 1993; Bourgeois et al., 1994). O B. cereus se desenvolve em alimentos com atividade de água igual ou superior a 0,95, e tem seu crescimento inibido pela nisina e ácido sórbico, na concentração de 0,20\% (Bourgeois et al., 1994).

$O B$. cereus ocorre naturalmente em alguns alimentos e pode produzir esporos, que permitem sua sobrevivência em condições ambientais adversas, como o congelamento e o cozimento. Assim, sua presença sugere a necessidade de uma manipulação eficiente para minimizar possíveis problemas, principalmente, em produtos que possam vir a ser enlatados, visto que este microrganismo pode produzir toxinas no alimento ou no trato intestinal, causando doenças, principalmente as cepas psicrotróficos que se desenvolvem 
em temperaturas de $4^{\circ} \mathrm{C}$ a $37^{\circ} \mathrm{C}$, inclusive quando o $\mathrm{pH}$ é superior a 6,0 . A acidificação dos alimentos a base de peixe, ao lado de outros processos de conservação, é importante para prevenir a colonização e formação de toxinas por estas cepas (Germano et al., 1993).

Bacillus cereus é encontrado em um grande número de alimentos, e é uma importante causa de intoxicação gastrintestinal. A característica de formação de esporo assegura a sobrevivência na maioria dos processamentos, e a refrigeração inadequada de pratos são veículos comuns para a germinação dos esporos e proliferação do microrganismo (Banwart, 1989). A maioria dos procedimentos para 0 isolamento e enumeração do $B$. cereus envolve 0 espalhamento de superfície em meio de cultura constituído por agar, manitol, gema de ovo e polimixina (MYP) (Peng et al., 2001).

Segundo Bourgeois et al. (1994) ainda que o B. cereus possa sobreviver em algumas semi conservas, principalmente do tipo pescado em azeite de oliva, é incapaz de produzir substâncias tóxicas. Para que haja contaminação, a contagem bacteriana deve atingir $10^{4}$ a $10^{5} \mathrm{UFC}^{-1}$ de alimento.

Muitos estudos indicam que o $B$. cereus é muito sensível aos efeitos antimicrobianos do $\mathrm{CO}_{2}$. Enfors \& Molin (1981) estabeleceram que de 11 microrganismos testados, o $B$. cereus foi o mais sensível à inibição em arenques filetados (Clupea harengus) armazenados sob atmosfera de $\mathrm{CO}_{2}$.

Tanto o $B$. cereus e $S$. aureus, estão freqüentemente envolvidos em surtos alimentares e são, conseqüentemente, isoladas em humanos. De acordo com dados de Departamento de Agricultura dos Estados Unidos (USDA), de 1993 a 1997, foram relatados 14 surtos e 691 casos, e 41 surtos e 1413 casos (1 morte), respectivamente, provocados pelo B. cereus e S. aureus, nos Estados Unidos (Lanciotti et al., 2001).

Fang et al. (1997), examinando a qualidade microbiológica de 155 produtos de cereais prontos para o consumo, indicaram o isolamento de $B$. cereus em cereais instantâneos e em mix de cereais em, respectivamente, $26 \%$ e $38 \%$ dos produtos. 
Estudos realizados por Lanciotti et al. (2001) apontam para o fato de que, através de modelos de crescimento para $B$. cereus e $S$. aureus, a interação da temperatura, atividade de água, $\mathrm{pH}$ e concentração de etanol podem ser quantificadas. Além disso, é possível identificar as combinações de tais fatores prevenindo o crescimento destes microrganismos. Estes resultados têm uma implicação prática na identificação das condições que podem ser aplicadas na preservação de alimentos para assegurar que nenhum crescimento destes microrganismos ocorra.

Segundo McMeekin et al. (2000), a definição dos parâmetros de crescimento, pode prover uma combinação precisa das condições nas quais novas técnicas de preservação de alimentos podem ser fundamentadas. Contudo, são necessárias investigações adicionais para o melhor entendimento dos mecanismos próximo da interface do crescimento ou não.

\subsubsection{Staphylococcus aureus}

O gênero Staphylococcus compreende três espécies, S. aureus, S. epidermis e S. saprophyticus. Destas, o $S$. aureus é a mais importante para a microbiologia de alimentos (ICMSF, 1983).

S. aureus é uma bactéria pequena, esférica, com diâmetro de 0,5 - 1 $\mu \mathrm{m}$, Gram-positiva, imóvel, distribuída em agrupações irregulares de células que lembram a cachos de uvas. São bactérias anaeróbicas facultativas; porém crescem melhor na presença de ar, sendo a temperatura ótima de crescimento $37^{\circ} \mathrm{C}$, porém desenvolvem-se até $10^{\circ} \mathrm{C}$ ou temperaturas ligeiramente menores. O S. aureus apresenta a característica pouco freqüente de tolerar baixas atividades de água $(0,86)$, e portanto, cresce a níveis altos de sal. Todas as cepas são coagulase positiva - possuem uma enzima que coagula o plasma sanguíneo -, porém, apenas 50\% produzem enterotoxinas associadas às toxinfeções alimentares (Hayes, 1993).

O Staphylococcus aureus produz uma ou mais enterotoxinas termo estáveis, responsáveis por surtos de envenenamento em alimentos (Jay, 1992). 
Um alimento no qual o $S$. aureus pode crescer e produzir enterotoxina é o queijo (Pareira et al. 1996), porém pode ser encontrado em outros alimentos de origem animal, e em alimentos manipulados por seres humanos portadores de S. aureus (Jay, 1992).

Em alimentos crus, especialmente produtos animais, a presença de $S$. aureus é comum e pode não estar relacionada com contaminação humana. Contaminação estafilocócica de couro aminal, penas e pele são comuns e podem ou não ser o resultado de lesões ou tecidos contundidos (Lancette \& Tatini,1992).

O Staphylococcus aureus há muito tempo é relacionado como o mais importante agente de intoxicação gastrintestinal no mundo, sendo o seu habitat primário as membranas mucosas do sistema respiratório humano e a pele de animais. Podem estar sempre presente ou estar passageiramente sem, no entanto, causar qualquer sintoma aos humanos (Genigiorgis, 1989).

A presença de $S$. aureus em alimentos prontos para servir está relacionada, freqüentemente, à manipulação imprópria por parte das pessoas que, freqüentemente, estão contaminadas com estes microrganismos (Hatakka et al., 2000). Como conseqüência direta da manipulação inadequada, são apontados os Streptococcus sp e o S. aureus (Germano et al., 1993; Adams et al., 1994; Cardonha et al., 1994), e que encontram no pescado ambiente favorável para sua multiplicação (Gelli, 1988).

O limite proposto pelo regulamento técnico sobre padrões microbiológicos em alimentos - Resolução - RDC n 12, de janeiro de 2001 é de $5 \times 10^{2}$ UFC $g^{-1}$ de S. aureus (ANVISA, 2003). Uma pesquisa realizada pelo Laboratório de Controle Sanitário da Prefeitura do Município de São Paulo no ano de 1989 , sinalizou que $25 \%$ das amostras de pescado comercializados na cidade de São Paulo apresentaram valores acima dos exigidos pela legislação vigente (Germano et al. 1993). Hoffmann, et al (1999) analisando o pescado comercializado na cidade de São José do Rio Preto,SP, detectaram que 82\% 
das amostras apresentaram-se em desacordo com a legislação para o parâmetro de S. aureus.

Ayulo et al. (1994), analisando peixes e mexilhões produzidos e comercializados no Estado de Santa Catarina, observaram a presença de $S$. aureus em 20\% das amostras analisadas, sendo que $60 \%$ das amostras de bivalves apresentaram S. aureus. Nesse estudo, também foi constatado que apenas 9 das 109 cepas de $S$. aureus produziram enterotoxina, incluindo as enterotoxinas A (4), D (1) e B (4).

Em estudos realizados na África, Staphylococcus sp. foram isolados de água de aquário e encontrados em águas de viveiros de aqüicultura, sendo os membros desse gênero relacionados como patógenos de organismos aquáticos (Nemetz e Shotts 1992). S. aureus foi associado a doenças de carpas (Hypophthalmichthys molitrix), causando mortalidade em fazendas de cultivo na Índia, no período de 1982 e 1983 (Shah \& Tyagy 1986).

De acordo com dados epidemiológicos, entre o período de 1986 a 1995, patógenos bacterianos foram relatados como causadores principais de vários surtos em Taiwan, na República de China (555 dos 852 surtos, 65\%), sendo o S. aureus (169 das 555 surtos, 30\%) e o B. cereus (104 das 555 surtos, 18\%), dois dos principais responsáveis por estes surtos (Pan et al., 1997).

Os tratamentos térmicos comumente aplicados como, por exemplo, pasteurização do leite e cocção de carne, e substâncias químicas usadas como agentes de sanificação, normalmente destroem as cepas de $S$. aureus. A presença após estes tratamentos pode indicar aquecimento ou sanificação insuficientes, ou contaminação depois da pasteurização ou cocção (Schoeller \& Ingham, 2001).

\subsection{Beneficiamento dos mexilhões}

O armazenamento de moluscos é limitado, se comercializados in natura; as valvas ocupam muito espaço dificultando o armazenamento e quando há beneficiamento, este é feito em uma parcela pequena da matéria-prima. A 
tendência é de se promover o crescimento da capacidade de armazenamento e estocagem destes produtos, buscando adequá-los aos novos processos de beneficiamento, garantindo a qualidade que o mercado exige (Beirão et al., 2000).

A temperatura é uma variável crítica na qualidade de alimentos frescos, especialmente em pescado, sendo que a estimativa da vida útil destes alimentos a qualquer temperatura de refrigeração seria de grande importância para o armazenamento de pescado, uma vez que as temperaturas de armazenamento na cadeia de distribuição comercial são variáveis (Charm et al., 1972).

A vida útil de um produto é basicamente determinada pelos componentes do sistema, tais como o processo utilizado; o método de embalagem; o tempo, temperatura e umidade durante o transporte e armazenamento. Os controles destes fatores vão retardadar ou prevenir o desenvolvimento dos efeitos (Dethmers, 1979).

Uma das grandes vantagens em processar este produto é o de poder apresentá-los de forma mais atraente que a tradicional, não exigindo, por exemplo, a difícil tarefa de desconchamento da ostra ainda crua, além de permitir a estocagem por tempo mais prolongado, dando flexibilidade ao seu consumo (Beirão et al., 2000).

\subsubsection{Tratamento térmico}

O processo térmico é a área chave no processamento de mexilhões para que se obtenham as propriedades sensoriais requeridas, além de inativar bactérias e enzimas visando produzir um alimento seguro e estável. Uma adequada vida útil é essencial para a demanda do mercado exportador, e para a expansão do mercado interno (Wood, 1979; Skipnes et al., 2002).

Durante o processamento de alimentos em geral, variáveis físicas importantes, como tempo e temperatura de cozimento influenciam na sobrevivência dos microrganismos, ou na persistência das toxinas responsáveis 
por doenças alimentares. O binômio tempo-temperatura de cozimento é um fator importante para assegurar a qualidade sanitária dos alimentos. Os binômios $65^{\circ} \mathrm{C}$ por $10 \mathrm{~min}$ ou $75^{\circ} \mathrm{C}$ por 5 min, foram estabelecidos como padrões para os alimentos, como letais para a maioria dos microrganismos patogênicos (Silva Júnior, 1995).

Pigott \& Tucker (1990) relatam que microrganismos patogênicos podem ser destruídos a temperaturas menores do que $100^{\circ} \mathrm{C}$, sendo que 0 procedimento de aumentar a temperatura interna dos alimentos para $66^{\circ} \mathrm{C}$ é normalmente suficiente para tornar o alimento seguro para o consumo.

O beneficiamento do mexilhão é iniciado com a cocção que permite a retirada das conchas e a ligeira pasteurização da carne. Após lavagem o mexilhão é cozido durante 6 min, em água à ebulição ou vapor a $100^{\circ} \mathrm{C}$; ou por 4 min, em vapor a $115^{\circ} \mathrm{C}$. Uma vez cozido e descascado, a carne pode ser resfriada e empacotada para ser comercializada ou destinada à industrialização (Espínola \& Dias, 1980).

No cozimento, os moluscos bivalves são expostos ao calor úmido por um tempo que varia de acordo com o tamanho do marisco, a velocidade de penetração do calor e as condições de aquecimento (Wood, 1979). Chai et al. (1994) estudaram o processo térmico para ostras e sugeriram um tratamento de $75-76^{\circ} \mathrm{C}$ por 8 min visando uma melhor qualidade; nesse estudo não foram consideradas outras temperaturas.

Antoniolli (1999), estudando a vida útil de mexilhões Perna perna processados e mantidos sob refrigeração, utilizou diferentes tempos de cozimento, desde 15 até $30 \mathrm{~min}$, obtendo temperaturas finais que variaram de 80 a $96^{\circ} \mathrm{C}$, e observou que todos os tratamentos térmicos aplicados foram satisfatórios quanto à eliminação dos microrganismos. Nesse estudo, foi também observado, que o cozimento dos mexilhões por $30 \mathrm{~min}$, atingindo a temperatura final de $96^{\circ} \mathrm{C}$, apresentou melhores características sensoriais, bem como melhorou o processo de desconchamento dos mexilhões. 
As indústrias de processamento de mexilhões utilizam altas temperaturas $\left(120^{\circ} \mathrm{C}-130^{\circ} \mathrm{C}\right)$ por um período de tempo relativamente pequeno - de 90 segundos a poucos minutos (Skipnes et al., 2002). Uma das grandes vantagens em processar estes produtos é o de poder apresentá-los de forma mais atraente que a tradicional, não exigindo, por exemplo, a difícil tarefa de desconchamento do pescado cru, além de permitir a estocagem por tempo mais prolongado, dando flexibilidade ao seu consumo (Beirão et al., 2000).

\subsubsection{Valor nutricional}

A utilização de moluscos bivalves como alimento data da época paleozóica, sendo a qualidade sanitária do ambiente aquático, onde estes são capturados ou cultivados, responsável diretamente pelos problemas de saúde pública que podem gerar quando consumidos, principalmente se ingeridos in natura (Santos, 1982). Segundo Fernández-Armesto (2004), os moluscos providos de conchas são consideradas uma comida eficiente, no sentido de que já vêm envoltos em uma concha funcional, quando dispostos à mesa, sendo este prato considerado extremamente nutritivo e apresentando desperdício mínimo.

O mexilhão apresenta pronunciada variação sazonal na composição de sua carne, com maior rendimento na época de desova. O valor energético da carne é de $80 \mathrm{kcal} 100 \mathrm{~g}^{-1}$, próximo ao dos peixes magros, enquanto que os mariscos e ostras possuem em média respectivamente, $76 \mathrm{kcal} 100 \mathrm{~g}^{-1} \mathrm{e}$ $44 \mathrm{kcal} 100 \mathrm{~g}^{-1}$. Possuem 1 a 7\% de glicogênio, teor elevado em relação às outras espécies de pescado, onde este carboidrato se encontra em baixa proporção. A fração protéica do pescado situa-se na faixa de 8,4\% a 17\%, já para mariscos e ostras os valores médios são de $13 \%$ e $6 \%$, respectivamente (Espínola \& Dias, 1980).

Medeiros et al. (1996) destacam que o mexilhão Perna perna apresenta pronunciada variação sazonal na composição de sua carne, com maior rendimento na época de desova. Segundo os autores, o mexilhão possui 


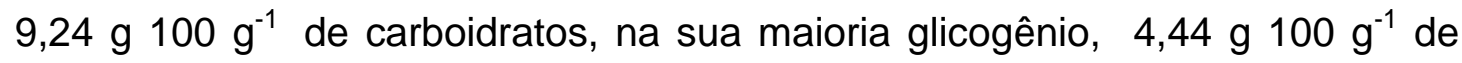
proteína, e de 5,24 g $100 \mathrm{~g}^{-1}$ de fração lipídica, sendo o valor energético de $108 \mathrm{kcal} 100 \mathrm{~g}^{-1}$.

Em trabalho realizado concomitantemente a esta pesquisa, foi avaliada a composição centesimal de mexilhões Perna perna proveniente de três locais de cultivo, em Ubatuba/SP, sendo encontrados os seguintes valores para umidade, lipídeos, cinza, proteína e carboidrato: 83,9 g $100 \mathrm{~g}^{-1}, 1,0 \mathrm{~g} 100 \mathrm{~g}^{-1}$, 1,9 g $100 \mathrm{~g}^{-1}$, 9,0 g $100 \mathrm{~g}^{-1}$ e 4,0 g $100 \mathrm{~g}^{-1}$, respectivamente (Porrelli et al., 2003; Furlan, 2004).

Furtado et al. (1998), estudando sururu (Mytella falcata), e berbigão (Anomalocardia brasiliana), obteve valores médios de umidade para a espécie M. falcata de $30,65 \%$ e de proteína de $56,44 \%$, enquanto que, para a espécie $A$. brasiliana os teores foram $25,62 \%$ e $48,14 \%$, respectivamente. O teor de lipídeos mostrou-se menor no molusco $M$. falcata, com média de 2,9\%, enquanto o $A$. brasiliana expressou um valor médio de 7,7\% e também apresentou-se mais rico nos teores de cinza (3,13\%) e carboidratos (15,18\%).

O processo de decomposição altera quase sempre a concentração de íons hidrogênio de um alimento. A determinação do pH é importante no caso do pescado, pois este é um alimento de baixa acidez (Tavares et al., 1988). Porém, a medida do $\mathrm{pH}$ não deve ser utilizada individualmente como índice de frescor, pois pode induzir a falsas avaliações. No entanto, seus valores geralmente acompanham, paralelamente, análises químicas, microbiológicas e sensoriais (Nort, 1988).

Quando comparados a outros tipos de pescado, os moluscos apresentam em sua carne um teor elevado de carboidratos e menores concentrações de nitrogênio. Conseqüentemente, a sua deterioração pode ser considerada de característica fermentativa. Outro fator qualitativo do pescado é quanto aos lipídeos, que possuem grande quantidade de ácidos graxos insaturados, sendo portanto, altamente susceptíveis à oxidação, a qual é acelerada pela presença de luz, calor e metais pesados (Beirão et al., 2000). 
Os macronutrientes minerais, assim definidos por sua abundância percentual no corpo humano, compreendem o cálcio (1,5 a 2,2\%), fósforo (0,8 a $1,2 \%)$, potássio $(0,35 \%)$, enxofre $(0,25 \%)$, sódio $(0,15 \%)$, cloro $(0,15 \%)$ e magnésio (0,05\%). Também podem ser definidos como macrominerais todos os minerais que existem no organismo em proporção superior a 0,05\% (Dutra-de Oliveira \& Marchini, 1998).

Os microminerais, também denominados "elementos-traço", são minerais necessários em pequenas quantidades diárias para manutenção do metabolismo e funcionamento adequado das células. Além de componente estrutural, eles exercem funções específicas no organismo, incluindo ação hormonal, atuando como co-fator enzimático ou estabilizador de reações químicas, entre elas a neutralização de radicais livres (Cunha \& Cunha, 1998).

O pescado pode ser uma excelente fonte de minerais fisiologicamente importantes, tais como, magnésio, manganês, zinco e cobre, com teores relativamente elevados, principalmente em alguns moluscos e crustáceos (Ogawa \& Maia, 1999). Segundo Contreras-Gusmán (1994), os moluscos possuem grandes quantidades de sódio, magnésio, ferro e zinco, se comparados com outros organismos de origem aquática.

Frutos do mar são comumente considerados como fontes de ferro (Nettleton, 1985); contudo apenas os mexilhões apresentam teores de ferro comparáveis aos de carne vermelha. Por exemplo, o conteúdo de ferro encontrado em mexilhões in natura (11 mg $100 \mathrm{~g}^{-1}$ ), é similar aos encontrados para carnes bovinas de primeira (Anderson et al., 1986).

Segundo Kongkachuichai (2002), bivalves crus ou cozidos, são tidos como boas fontes de ferro heme e total, variando-se de 2,5 a 9,1 mg $100 \mathrm{~g}^{-1} \mathrm{e}$

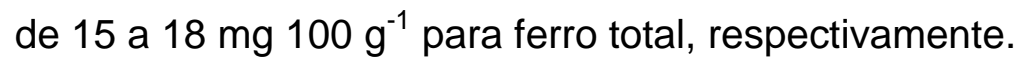

Dentre as fontes de zinco na alimentação, encontram-se produtos integrais, levedo de cerveja, farelo e germe de trigo; os frutos do mar e as carnes são, geralmente, melhores fontes de zinco biodisponível que os vegetais 
(Hendler, 1994). A interação do zinco com outros nutrientes da alimentação pode aumentar ou diminuir sua absorção (Cunha \& Cunha, 1998).

Uma alimentação variada geralmente contém cobre em quantidade suficiente para a maioria dos indivíduos saudáveis. Fontes ricas em cobre incluem o fígado animal, frutos do mar, castanhas e nozes (Hendler, 1994). Carnes, frango, peixe, ovos e cereais processados também são fontes. A quantidade de cobre em frutas e vegetais verdes depende do cultivar, concentração de cobre no solo e condições de cultivo (Cunha \& Cunha, 1998).

Em estudos realizados por Furtado et al. (1998), a espécie M. falcata revelou um teor médio de 1,38\% e 8,45\% destes componentes. Quanto aos minerais, o zinco apresentou teores de maior expressão: 70,5 mg para M. falcata e $68,8 \mathrm{mg}$ para $A$. brasiliana. A quantidade média de cálcio encontrada para o $M$. falcata foi de $53,7 \mathrm{mg}$ e para o A. brasiliana 49,5 mg, comprovando assim a importante colaboração destes bivalves como fontes de nutrientes na alimentação de populações litorâneas

\subsubsection{Análise sensorial}

A qualidade sensorial de peixes e outros produtos de origem marinha depende de muitos processos os quais são governados por mecanismos químicos, bioquímicos e microbiológicos e, a perda de frescor do pescado refrigerado é o reflexo da atividade desses processos (Stone \& Sidel, 1993).

A carne de moluscos recém capturados apresenta um odor típico de fresco, em produtos preparados apresenta-se leitoso com aroma agradável. A ação de fechar as valvas quando estão abertas, a elasticidade da carne e cores vivas, são sinais de frescor. Os moluscos requerem temperaturas não inferiores a $10^{\circ} \mathrm{C}$ e elevada umidade, para permanecerem vivos por determinado tempo (Bertullo, 1975; Beirão et al., 2000).

As pessoas consomem frutos do mar por causa de seu alto valor nutritivo e pelo seu sabor característico e diversificado. Estas características devem estar presentes qualitativamente e quantitativamente, não só nos alimentos 
processados, como nos produtos do tipo surimi, bem como no alimento original, como por exemplo, peixes e molusco cultivados, que eventualmente adquirem sabor menos pronunciado que os mesmos em estágio selvagem (Haard, 1992).

Pesquisas nesta linha têm enfocado a extração deste sabor ativo, em resíduos de camarão. Estas substâncias poderiam ser utilizadas como estimuladores de alimentação ou como saborizante em peixes e frutos do mar, ou poderiam ser incorporados em sopas ou produtos do tipo surimi ( Mandeville et al., 1991; Mandeville et al., 1991).

Muitos são os componentes responsáveis pelo sabor e aroma em frutos do mar, tais como aminoácidos livres (glicina, alanina, prolina, ácido glutâmico, metionina e histidina), di-peptídios (anserina e balenina), nucleotídeo e compostos relacionados (inosina monofosfato, guanosina monofosfato e hipoxantina), amônia quaternária e ácidos orgânicos (Cambero et al., 1998).

Segundo Cambero et al. (1998), o sabor característico da carne de caranguejo é dado por oito componentes nitrogenados, entre eles glicina, alanina, e GMP, e quatro íons inorgânicos $\left(\mathrm{Na}^{+}, \mathrm{K}^{+}, \mathrm{Cl}^{-}\right.$e $\left.\mathrm{PO}_{43}\right)$. Neste estudo, os autores sugerem que o sabor de alguns frutos do mar em particular, deve ser originado de componentes específicos, e não necessariamente devido a diferentes concentrações das mesmas substâncias.

Peixes cartilaginosos e crustáceos são propensos à rápida deterioração, a partir de compostos nitrogenados simples, que irão rapidamente produzir odores e sabor ruins (Linton et al., 2003).

Os diferentes estudos de aroma e sabor em crustáceos cozidos utilizam uma grande variedade de tratamentos térmicos. Em 1978, Konosu et al., citado por Cambero et al. (1998), estudaram os componentes de sabor de caranguejos cozidos em uma solução salina (3\% de NaCl) por 15 -25 min. Em 1990, Shenderyuk et al., citado pelo mesmo autor, submeteram à cocção camarões em uma solução de $\mathrm{NaCl}$ 8\% por 15 min, para investigar os componentes nitrogenados voláteis e o papel deles no aroma de camarões cozidos. 


\section{MATERIAL E MÉTODOS}

O presente trabalho foi realizado no Laboratório de Microbiologia e no Setor de Processamento de Alimentos, do Departamento de Agroindústria, Alimentos e Nutrição, da Escola Superior de Agricultura "Luiz de Queiroz", ESALQ-USP, em Piracicaba-SP.

\subsection{Coleta das amostras}

As amostras de mexilhão Perna perna, foram coletadas em um cultivo comercial localizado no Costão da Praia do Cedro, em Ubatuba-SP (233'45.5'S, 4509'32.9'W). Foram coletados mexilhões de tamanho comercial, entre 5 e $7 \mathrm{~cm}$, durante os meses de novembro de 2003 a março de 2004.

Os mexilhões coletados foram submetidos ao processo de desdobre, no qual eram retirados do cacho, separados da fauna acompanhante, e submetidos à limpeza para a retirada de cracas e parasitas. Posteriormente, foram lavados com água do mar, efetuando-se assim a limpeza superficial das valvas (Figura 1).

Após esse processo, foram acondicionados em sacos de ráfia, colocados em caixas de isopor, com medidas internas de $35 \mathrm{~cm} \times 40 \mathrm{~cm} \times 25,5 \mathrm{~cm}(35,7$ litros), contendo gelo na proporção de 1:1, sem, no entanto, contato direto com gelo, evitando-se assim a morte dos mexilhões. As amostras então foram transportadas para os Laboratórios do Departamento de Agroindústria, Alimentos e Nutrição, da ESALQ-USP (Figura 2). 


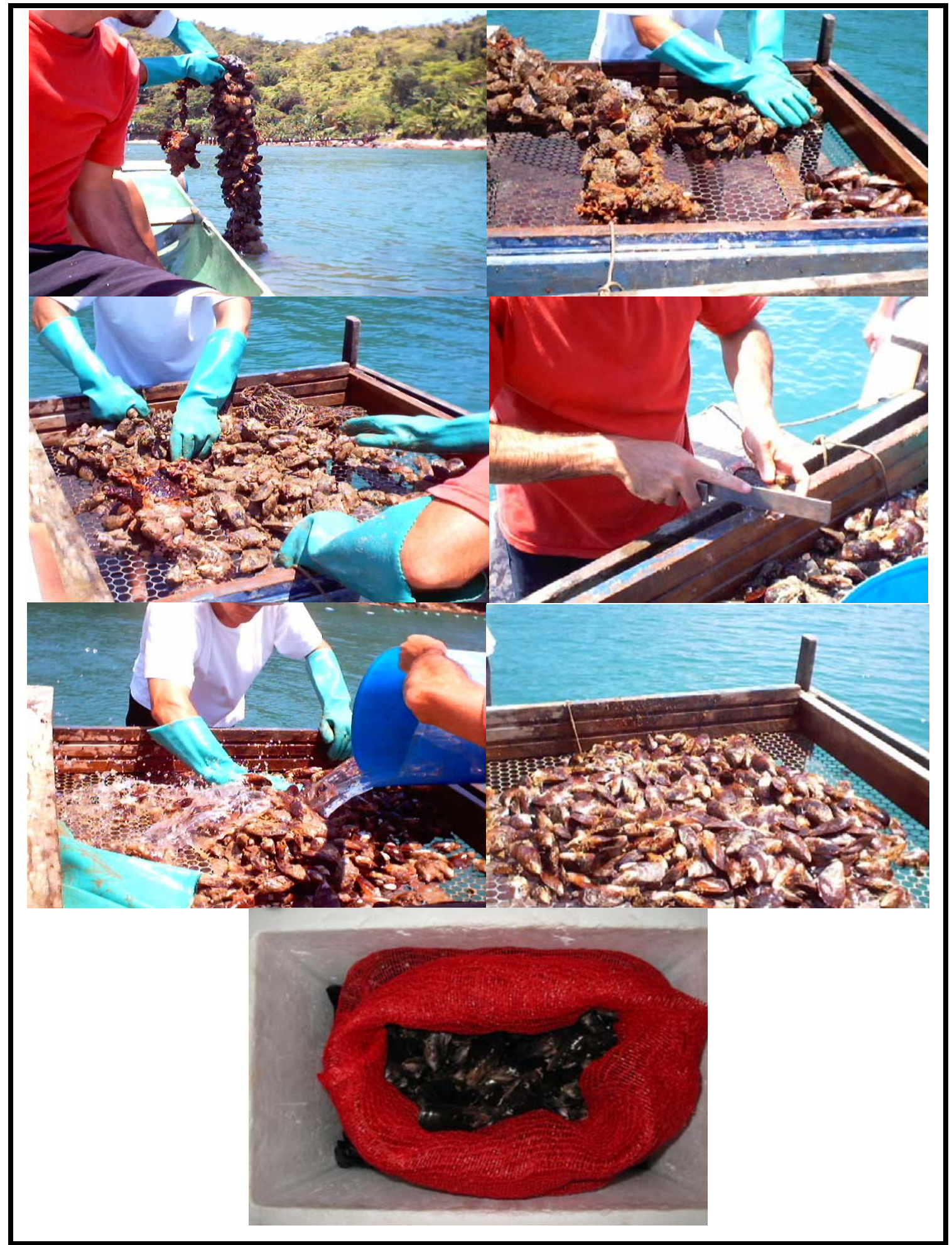

Figura 1 - Coleta, desdobre, limpeza e transporte dos mexilhões. 


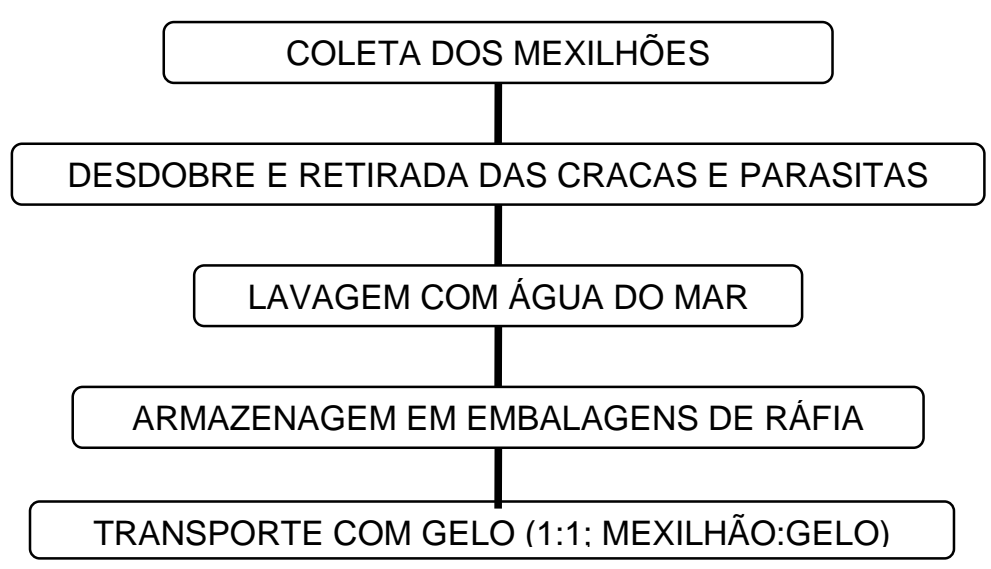

Figura 2 - Procedimento de preparo dos mexilhões

\subsection{Inóculo}

Como inóculo para Staphylococcus aureus, foi utilizada uma cepa IZ 1974, que foi mantida à temperatura ambiente em tubos contendo ágar nutriente (NA) (Merck) inclinado. Essa cultura foi reativada em caldo Brain Heart Infusion (BHI) (Oxoid), por 24 horas a $36^{\circ} \mathrm{C} \pm 1^{\circ} \mathrm{C}$.

Para a inoculação do Bacillus cereus, foi utilizada uma cepa CCT 0198, mantida a temperatura ambiente em tubos contendo ágar nutriente inclinado. Essa cultura foi reativada em caldo nutriente (NB) (Merck), por 24 horas a $36^{\circ} \mathrm{C} \pm 1^{\circ} \mathrm{C}$.

\subsubsection{Determinação da curva de crescimento}

A determinação da curva de crescimento foi realizada com o intuito de se determinar a taxa de crescimento dos microrganismos. A partir desta curva, pode-se determinar o tempo necessário de incubação das cepas reativadas, para se obter um inóculo com $10^{8} \mathrm{UFC}^{-1}$.

As culturas reativadas foram inoculadas em $100 \mathrm{~mL}$ de caldo BHI, e incubadas a $36^{\circ} \mathrm{C} \pm 1^{\circ} \mathrm{C}$. Desta suspensão, foram retiradas alíquotas de $0,1 \mathrm{~mL}$ em intervalos regulares de 1 hora, para a determinação da população de 
bactérias. Estas alíquotas foram inoculadas em placas contendo ágar $\mathrm{BHI}$ solidificado, pelo método de espalhamento em superfície, com a ajuda de uma alça de Drigasky, e incubadas invertidas a $36^{\circ} \mathrm{C} \pm 1^{\circ} \mathrm{C}$, por 24 horas. A partir desta curva, foi estimado o tempo para a retirada de uma alíquota que fornecesse uma população próxima a $10^{8} \mathrm{UFC} \mathrm{g}^{-1}$.

\subsubsection{Preparo da solução para inoculação}

Determinada a curva de crescimento, onde foi determinado o tempo necessário para a obtenção de um inóculo com $10^{8} \mathrm{UFC} \mathrm{g}^{-1}$, procedeu-se à inoculação dos mexilhões.

A partir da cultura reativada por 24 horas, $1 \mathrm{~mL}$ foi inoculado em $100 \mathrm{~mL}$ de $\mathrm{BHI}$, sendo incubado por 6 horas a $37^{\circ} \mathrm{C}$. Em seguida, uma alíquota de $1 \mathrm{~mL}$ foi suspensa em $10 \mathrm{~L}$ de uma solução salina 0,7\%, onde foi inoculado $1 \mathrm{~kg}$ de mexilhão in natura ou cozido desconchado.

\subsection{Preparo da amostra e Inoculação}

As conchas dos mexilhões foram lavadas sob água corrente com o auxílio de uma escova estéril, e distribuídos em papel toalha para retirada da água de lavagem (Vanderzant \& Splittstoesser, 1992). O lote então foi separado em 2 sub-lotes, um para análise in natura e o outro para análise do material cozido e desconchado (Figura 3).

Após a limpeza, foi realizada uma pré-cocção de um dos sub-lotes, por imersão em água à ebulição, até que as conchas estivessem abertas, por aproximadamente $5 \mathrm{~min}$, sendo posteriormente mergulhados em água e gelo, para que fossem resfriados rapidamente até a temperatura interna de $10^{\circ} \mathrm{C}$, e retirados das conchas.

Os mexilhões in natura e cozidos desconchados foram mergulhados por 30 min em uma suspensão de água salina 0,7\% e inóculo, na proporção de 10L:1 mL (água: inóculo), para cada quilo de mexilhão. Após esse período, os mexilhões foram escorridos por 15 min e depositados em recipientes estéreis. 


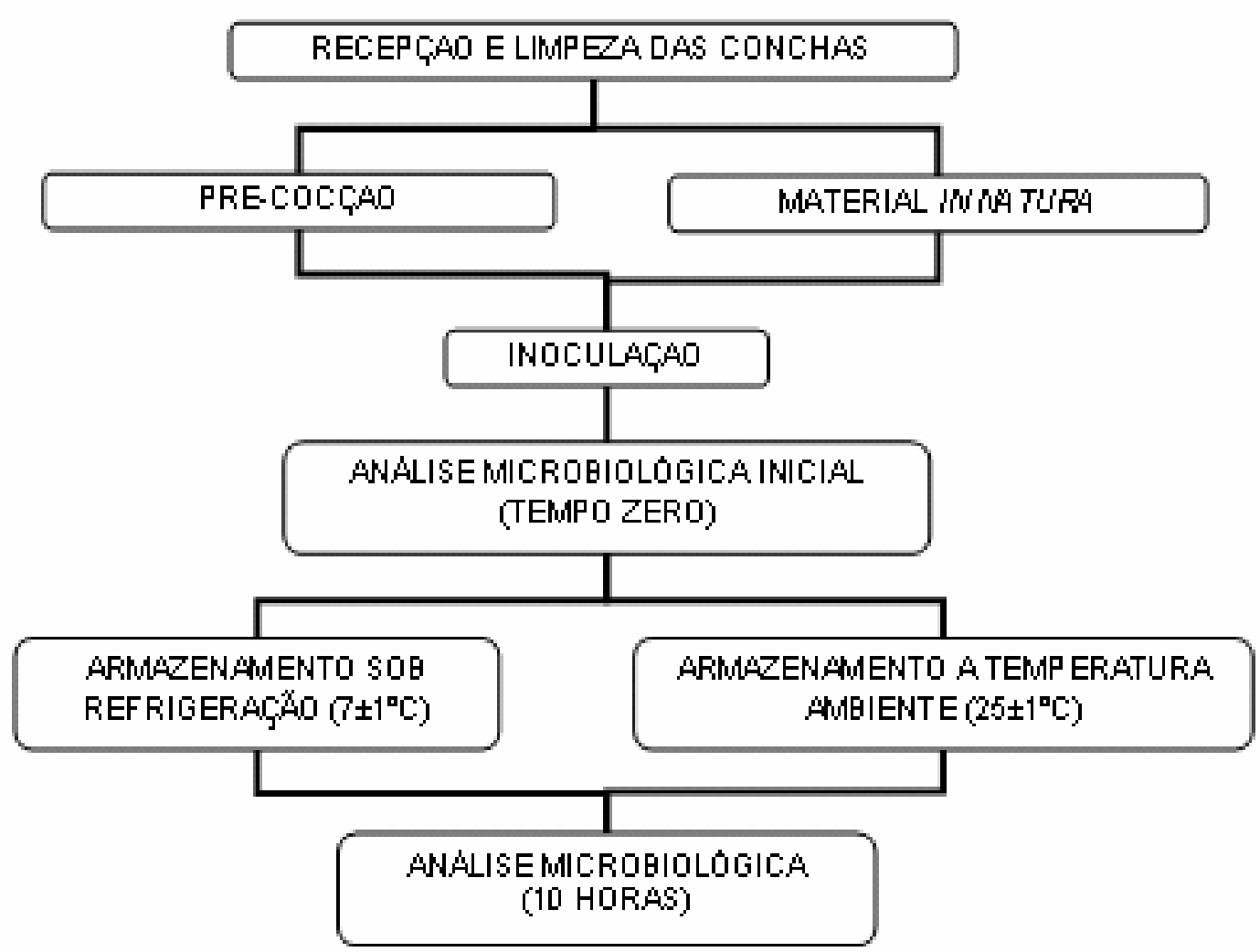

Figura 3 - Procedimentos de processamento e análises microbiológicas dos mexilhổes

Os dois tratamentos foram então divididos novamente em três amostras: um para análise imediata; um armazenado a temperatura de refrigeração $\left(7 \pm 1^{\circ} \mathrm{C}\right)$, e outro armazenado a temperatura ambiente $\left(25 \pm 1^{\circ} \mathrm{C}\right)$, por 10 horas.

\subsection{Análises microbiológicas}

Os mexilhões in natura foram abertos pela região do bisso, com o auxílio de faca, forçando as conchas, permitindo assim a drenagem da água das conchas e a retirada total da carne, que foi depositada em becker estéril (Vanderzant \& Splittstoesser, 1992). 


\subsubsection{Preparo das diluições}

De cada tratamento, retirou-se 3 amostras de 25 gramas para serem trituradas em liquidificador, em copo estéril, adicionando-se $225 \mathrm{~mL}$ de diluente (água peptonada 0,5\% esterilizada), obtendo-se uma diluição $10^{-1}$. As amostras então foram trituradas por $1 \mathrm{~min}$, para evitar um excessivo aquecimento das mesmas (Vanderzant \& Splittstoesser, 1992).

A seguir, foram realizadas as diluições decimais seriadas. A diluição $10^{-2}$ foi obtida retirando-se $10 \mathrm{~mL}$ da diluição $10^{-1}$ e adicionando-se $90 \mathrm{~mL}$ de água peptonada $0,5 \%$ esterilizada. As demais diluições foram realizadas pelo mesmo procedimento, retirando-se $10 \mathrm{~mL}$ da diluição anterior, adicionando-se a $90 \mathrm{~mL}$ de água peptonada 0,5\%. Na obtenção de cada diluição, os frascos foram agitados de maneira vigorosa (Silva et al., 1997).

As diluições foram plaqueadas em função do nível estimado de contaminação, de modo a se obter placas com contagens entre 30 a 300 unidades formadoras de colônias (UFC), evitando-se assim contaminações externas ou sobreposições de colônias, sendo os resultados apresentados em UFC $g^{-1}$.

\subsubsection{Contagem de Bacillus cereus}

Para a contagem presuntiva de Bacillus cereus foi utilizado o método de contagem direta em placas, segundo Vanderzant \& Splittstoesser (1992). Foi inoculado $1 \mathrm{~mL}\left(0,3,0,3,0,3\right.$ e 0,1 mL) da diluição de $10^{-3}$ e $0,1 \mathrm{~mL}$ das diluições de $10^{-4}$ e $10^{-5}$, para o mexilhão in natura, e $1 \mathrm{~mL}(0,3,0,3,0,3$ e $0,1 \mathrm{~mL}) \mathrm{da}$ diluição de $10^{-5}$ e $0,1 \mathrm{~mL}$ das diluições de $10^{-6}$ e $10^{-7}$, para o mexilhão cozido.

Os inóculos foram espalhados em duplicata, com uma alça de Drigalsky, em placas de Petri com Ágar Manitol Yolk Polymyxin (MYP) (Merck), previamente adicionado de emulsão de gema de ovo (Oxoid) e Polimixina B (Oxoid), até que todo o excesso de líquido fosse absorvido.

Após a secagem completa, as placas foram incubadas invertidas a $36^{\circ} \mathrm{C} \pm 1^{\circ} \mathrm{C}$ por 20 a $24 \mathrm{~h}$. Após esse período, as colônias típicas (grandes, sem 
forma específica, rosa, rodeadas de uma zona opaca) foram selecionadas para os testes confirmativos de Gram e catalase. Algumas colônias típicas foram inoculadas em caldo $\mathrm{BHI}$ e incubadas a $36^{\circ} \mathrm{C} \pm 1^{\circ} \mathrm{C}$ por $24 \mathrm{~h}$, para a realização das outras provas de identificação: motilidade, redução de nitrato, decomposição da tirosina, crescimento rizóide e teste de Voges-Proskauer (VP).

1. Catalase: adição de gotas de água oxigenada (peróxido de hidrogênio) $3 \%$ sob as colônias selecionadas, aparecimento de borbulhamento imediato

2. Motilidade: inoculação com uma agulha da suspensão (cultura $+\mathrm{BHI}$ ) em tubos contendo ágar motilidade solidificado (Sim médium - Merck), por $36^{\circ} \mathrm{C} \pm 1^{\circ} \mathrm{C}$ por $24 \mathrm{~h}$, observando-se o crescimento difuso.

3. Redução do nitrato: inoculação da suspensão em tubos contendo caldo nitrato (Difco), a $36^{\circ} \mathrm{C} \pm 1^{\circ} \mathrm{C}$ por $24 \mathrm{~h}$, posteriormente adicionado de 0,25 $\mathrm{mL}$ de ácido sulfanílico $0,8 \%$ e $0,25 \mathrm{~mL}$ de solução de alfa naftilamina $0,5 \%$, sendo observado a coloração laranja devido à redução do nitrato a nitrito pelo $B$. cereus.

4. Decomposição da tirosina: estriamento na superfície da suspensão da cultura em ágar nutriente (Merck) inclinado contendo 0,5\% de tirosina, a $36^{\circ} \mathrm{C} \pm 1^{\circ} \mathrm{C}$ por 48 a $72 \mathrm{~h}$, observado a decomposição da tirosina por membros do grupo de $B$. cereus.

5. Crescimento de rizóide: inoculação com uma agulha no centro de placas contendo ágar nutriente (Merck) solidificado, $36^{\circ} \mathrm{C} \pm 1^{\circ} \mathrm{C}$ por $24 \mathrm{~h}$, observando-se a ausência de crescimento em rizóide, pelo $B$. cereus.

6. Teste VP: inoculação da suspensão da cultura em tubos contendo MRVP Broth (Merck) , a $36^{\circ} \mathrm{C} \pm 1^{\circ} \mathrm{C}$ por $48 \mathrm{~h}$, posteriormente adicionado de 0,2 $\mathrm{mL}$ de hidróxido de potássio $40 \%$ e 0,6 $\mathrm{mL}$ de solução alcoólica de alfa-naftol 5\%, sendo observada a coloração roxa em alguns minutos devido à produção de Acetilmetilcarbinol a partir de glicose pelos membros do grupo do $B$. cereus. 


\subsubsection{Contagem de Staphylococcus aureus}

Para a contagem presuntiva de Staphylococcus aureus foi utilizado o método de contagem direta em placas, segundo Vanderzant \& Splittstoesser (1992). Foi inoculado $1 \mathrm{~mL}\left(0,3,0,3,0,3\right.$ e 0,1 mL) da diluição de $10^{-3}$ e $0,1 \mathrm{~mL}$ das diluições de $10^{-4}$ e $10^{-5}$, para o mexilhão in natura, e $1 \mathrm{~mL}(0,3,0,3,0,3$ e $0,1 \mathrm{~mL}$ ) da diluição de $10^{-5}$ e $0,1 \mathrm{~mL}$ das diluições de $10^{-6}$ e $10^{-7}$, para o mexilhão cozido.

Os inóculos foram espalhados em duplicata, com uma alça de Drigalsky, em placas de Petri com Ágar Baird-Parker (BPA) (Merck), previamente adicionado de gema de ovo telurita (Oxoid), até que todo o excesso de líquido fosse absorvido. Após a secagem completa, as placas foram incubadas invertidas a $36^{\circ} \mathrm{C} \pm 1^{\circ} \mathrm{C}$ por $48 \mathrm{~h}$. Após esse período, as colônias típicas (pretas, brilhantes, circulares, lisas, convexas, e com halo transparente ao redor) foram selecionadas para que os testes confirmativos de Gram, catalase e coagulase.

No teste de Catalase, adicionou-se algumas gotas de água oxigenada (peróxido de hidrogênio) 3\% nas colônias selecionadas, observando-se o imediato borbulhamento. Para o teste de Coagulase, algumas colônias típicas foram inoculadas em caldo $\mathrm{BHI}$ (Oxoid) e incubadas a $36^{\circ} \mathrm{C} \pm 1^{\circ} \mathrm{C}$, por $24 \mathrm{~h}$. Dessa suspensão, foram retirados $0,2 \mathrm{~mL}$ para um tudo e adicionando $0,5 \mathrm{~mL}$ de plasma de coelho liofilizado, previamente, adicionado de solução salina. Misturou-se em rotação, sem agitação, e incubou-se por $6 \mathrm{~h}$ a $37^{\circ} \pm 1^{\circ} \mathrm{C}$, verificando-se a ocorrencia de coagulação.

\subsection{Tratamentos térmicos dos mexilhões}

Inicialmente, os mexilhões foram lavados sob água corrente com o auxílio de uma escova estéril, e distribuídos em papel toalha para retirada da água de lavagem (Vanderzant \& Splittstoesser, 1992).

O lote de mexilhões, foi dividido em 2 sub-lotes de $6 \mathrm{~kg}$, que foram inoculados, separadamente, com uma suspensão de $B$. cereus e de $S$. aureus. 
Após a inoculação, os sub-lotes foram separados em 6 amostras de $1 \mathrm{~kg}$ cada, que foram submetidos aos seguintes tempos de cozimento: $5 \mathrm{~min}, 10 \mathrm{~min}$ e 15 min em vapor, e 5 min, 10 min e 15 min imerso em água. Os mexilhões foram submetidos à cocção, sendo colocados em cestos de arame $(20 \mathrm{~cm}$ de diâmetro superior $\times 16,5 \mathrm{~cm}$ de diâmetro inferior $\times 10 \mathrm{~cm}$ de altura) suspensos em um recipiente de inox $(24,5 \mathrm{~cm}$ de diâmetro $x 14 \mathrm{~cm}$ de altura) com tampa.

A temperatura de cozimento foi monitorada com o auxílio de um conjunto de termopares tipo T com 5 sensores calibrados, sendo distribuídos da seguinte maneira: um no fundo do recipiente, outro no meio, e um na superfície, e outro no centro da massa de mexilhões. O quinto termopar foi colocado no recipiente de resfriamento, onde os mexilhões foram mergulhados em água com gelo, na proporção de $3: 1$, até atingirem a temperatura interna de $10^{\circ} \mathrm{C}$.

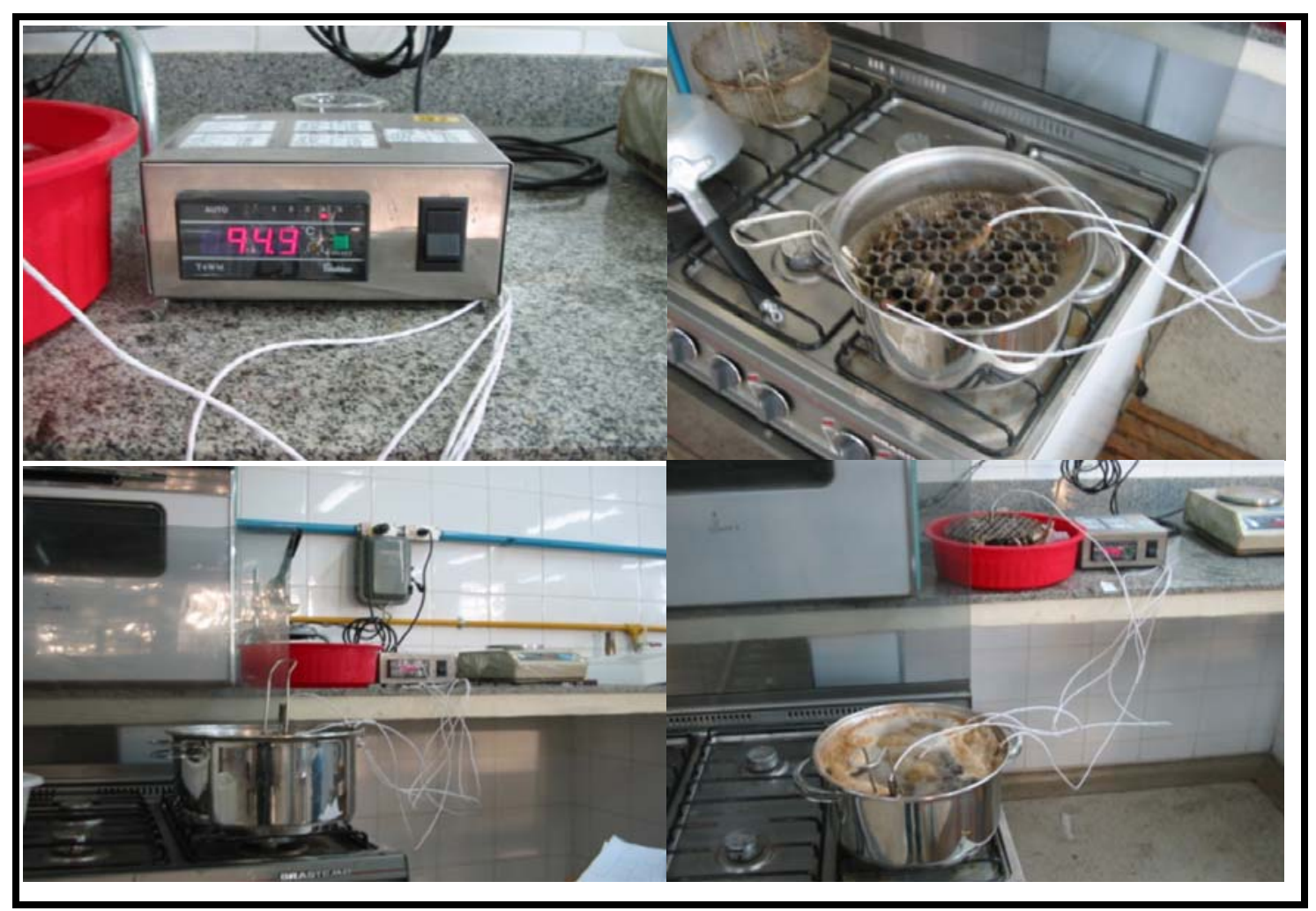

Figura 4 - Tratamento térmico dos mexilhões 


\subsection{Análise microbiológica dos mexilhões cozidos}

Após os cozimentos, os mexilhões foram removidos de suas conchas e acondicionados em copo Becker estéril e, imediatamente, conduzidos às análises. De cada tratamento, foram retiradas 3 alíquotas de $25 \mathrm{~g}$ do molusco, que foram transferidas para um copo estéril de liquidificador contendo $225 \mathrm{~mL}$ de água peptonada 0,5\%, e homogeneizado por $60 \mathrm{seg}$, obtendo-se assim a diluição $10^{-1}$. A partir desta foram realizadas diluições décimas subseqüentes até $10^{-6}$. Para ambos os microrganismos, $1 \mathrm{~mL}$ de cada diluição foi inoculada em serie de três tubos, em duplicata, os quais continham $9 \mathrm{~mL}$ de caldo $\mathrm{BHI}$ (Oxoid).

Estas séries de tubos foram inoculadas a $36 \pm 1^{\circ} \mathrm{C}$ por $18 \mathrm{~h}$ e após 0 período de incubação o material de cada tubo foi semeado com alça em estrias, no caso de $S$. aureus, e com uma agulha, no caso do $B$. cereus, de maneira a se obter colônias isoladas, em placas contendo ágar BPA (Merck) e ágar MYP (Merck), respectivamente. As placas foram incubadas a $36 \pm 1^{\circ} \mathrm{C}$ por 24 horas, no caso do B. cereus, e 48 horas, no caso do S. aureus. As colônias suspeitas de cada microrganismo, foram identificadas conforme descrito em 4.3 e 4.4. Os resultados são apresentados em NMP $\mathrm{g}^{-1}$.

\subsection{Análise Físico-química}

As análises físico-químicas realizadas foram:

3.7.1 Determinação do pH: determinado em potenciômetro digital Digimed, utilizando-se amostra (carne + líquido intravalvar) triturada com água, na proporção de 1:1 (AOAC, 1995).

\subsubsection{Composição Centesimal}

Umidade: realizada em estufa através da perda de peso da amostra aquecida a $105^{\circ} \mathrm{C} \pm 1^{\circ} \mathrm{C}$, até peso constante, de acordo com AOAC (1995). 
Proteína: realizada mediante a determinação do nitrogênio total, pelo método de Kjeldahl, e conversão em proteína multiplicando o valor obtido pelo fator 6,25, conforme a AOAC (1995).

Lipídeos: foram determinados através do método Soxhlet, utilizando-se hexano como solvente extrator, conforme AOAC (1995).

Cinza: foi analisada por incineração da matéria orgânica e posteriormente as amostras, para total calcinação, foram levadas à mufla a $550^{\circ} \mathrm{C}$, até peso constante, segundo AOAC (1995).

\subsubsection{Determinação de Minerais}

As análises químicas para a determinação dos teores de minerais presentes no material seco foram efetuadas após digestão nítrico-perclórica, utilizada na obtenção dos extratos para as determinações de fósforo, potássio, cálcio, magnésio, enxofre, cobre, ferro, manganês e zinco.

O fósforo foi determinado por colorimetria de vanadato-molibdato e o enxofre por turbidimetria, em espectrofotômetro digital Micronal B34211, em comprimento de onda de 420nm. O potássio foi determinado por fotometria de chama, e os demais minerais por espectrofotometria de absorção atômica, em equipamento Perkin Elmer 3110.

Para a determinação do boro, foi realizada uma digestão por via seca, em mufla a $550^{\circ} \mathrm{C}$ por $2 \mathrm{~h}$, e posterior determinação por colorimetria de azometina $\mathrm{H}$, em espectrofotômetro digital Micronal B34211, com comprimento de onda de 420nm.

\subsection{Rendimento e Biometria}

O cálculo do rendimento foi realizado com o objetivo de se verificar possíveis perdas no rendimento de mexilhões em função do tempo de cocção, sendo adotadas duas formas de cálculo: uma levando-se em conta o peso total dos mexilhões, e a outra considerando apenas a parte comestível. 
Antes de cada tratamento as amostras in natura foram pesadas e, após o desconchamento, a carne e as conchas com os resíduos, foram pesadas separadamente. O rendimento foi obtido utilizando-se as seguintes fórmulas:

Peso total (em \%)
Peso da Carne cozida

Peso do mexilhão in natura

$\begin{aligned} & \text { Parte comestível } \\ & (\text { em } \%)\end{aligned}=\frac{\text { Peso da carne cozida }}{(\text { Peso do mexilhão in natura }- \text { peso da concha })} \times 100$

A biometria se constitui na medida das valvas de 100 indivíduos, de cada coleta, com o auxílio de um paquímetro.

\subsection{Análise Sensorial}

O teste de ordenação permite comparação de 3 ou mais amostras com relação a um atributo, porém os resultados são simplesmente ordinais e não obtém o grau de diferença entre as amostras (ABNT, 1994). O teste consiste na apresentação das amostras de maneira casualizada e balanceada e os julgadores são solicitados a ordená-las, colocando as amostras em ordem crescente, quanto à intensidade de um determinado atributo. Os resultados são calculados pela soma das ordens para cada amostra e avaliados estatisticamente pelo teste de Friedman, utilizando-se os dados da tabela de Newell \& MacFarlane (1987).

As amostras foram servidas simultaneamente, sob delineamento aleatório, e solicitado aos provadores que as rearranjassem por ordenação em ordem crescente (Meilgaard et al., 1991). A equipe foi composta de 50 provadores não treinados, porém conhecedores do produto, sendo solicitado a eles que dessem sua opinião quanto à apreciação geral do produto, anotandose na ficha de análise sensorial, conforme figura 5. 
Nome:

Data:

I

Você está recebendo 4 amostras de mexilhão. Por favor, prove as amostras da esquerda para a direita e ordene-as em ordem decrescente, de acordo com a sua preferência.

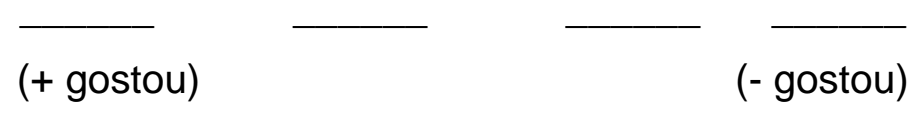

Obs:

Figura 5 - Modelo de ficha para análise sensorial

\subsection{Análises Estatísticas}

Os resultados das análises fisico-químicas foram submetidos à análise de variância, através do programa SAS (1999). As médias foram comparadas entre si, pelo teste de Tukey, adotando-se o nível de significância de 5\%. 


\section{RESULTADOS E DISCUSSÃO}

\subsection{Curva de Crescimento}

A figura 6 apresenta as curvas de crescimento para o Bacillus cereus e Staphylococcus aureus. Através da curva de crescimento, foi possível determinar o tempo necessário de incubação das cepas para se obter um inoculo com $10^{8}$ UFC $\mathrm{mL}^{-1}$.

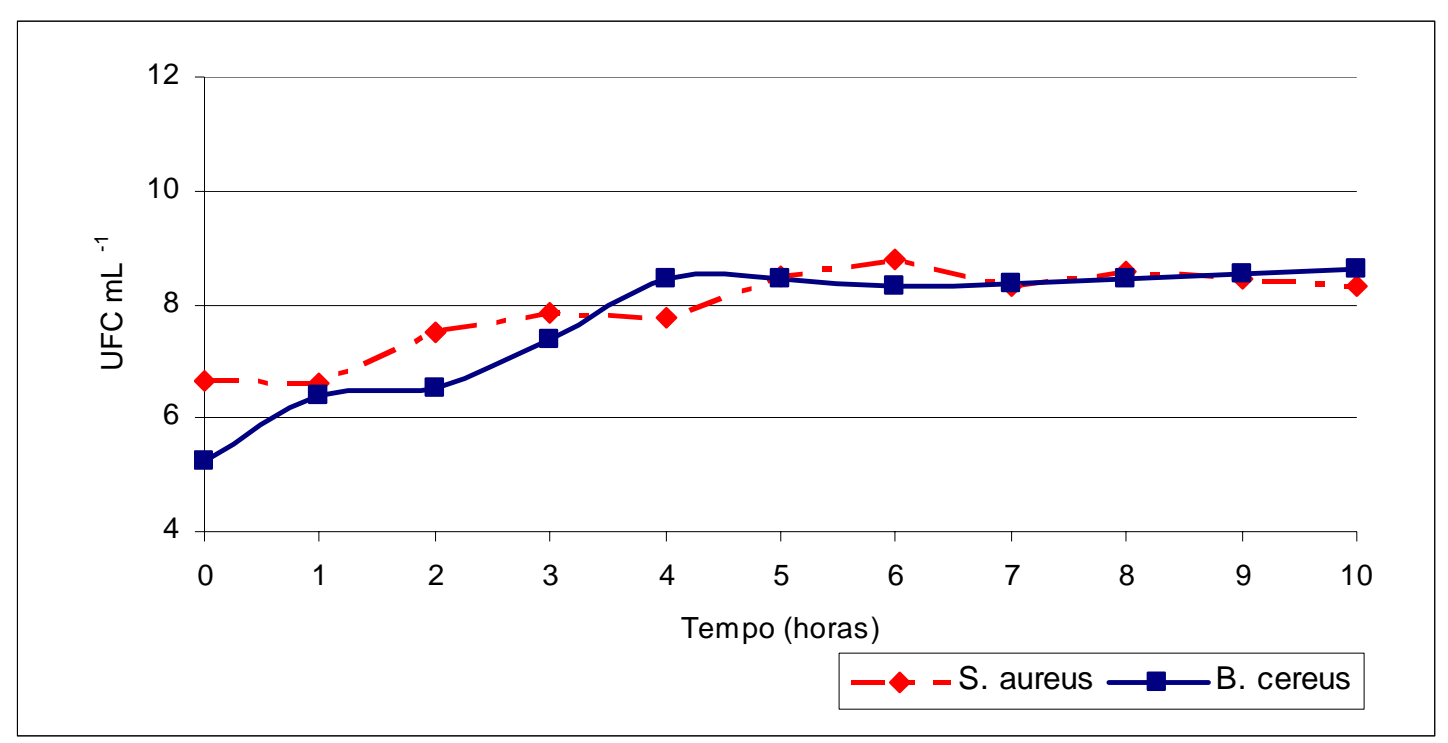

Figura 6 - Curvas de crescimento para Bacillus cereus e Staphylococcus aureus

Analisando-se a Figura 6, pode-se observar que com 6 horas de incubação, ambos os microrganismos obtiveram a contagem de $10^{8} \mathrm{UFC} \mathrm{\textrm {mL } ^ { - 1 }}$ de inóculo, contagem esta pré-estabelecida em estudos preliminares, como ideal para a contaminação de ambos os microrganismos. 
A determinação da contagem inicial do inóculo, foi baseada em alguns autores, entre eles Guimarães (2002), que inoculando cerca de $10^{7} \mathrm{UFC} \mathrm{g}^{-1}$ de Vibrio parahaemolyticus em carne de moluscos Anomalocardia brasiliana, obteve contagens iniciais, no molusco, de $10^{6} \mathrm{UFC} \mathrm{g}^{-1}$.

\subsection{Análises Microbiológicas - Inoculação}

A Tabela 1 e a Figura 7, apresentam os resultados do crescimento do Staphylococcus aureus, inoculado em mexilhões in natura e nos submetidos à pré-cocção, mantidos a temperatura ambiente $\left(25^{\circ} \mathrm{C} \pm 1^{\circ} \mathrm{C}\right)$ e sob refrigeração $\left(7^{\circ} \mathrm{C} \pm 1^{\circ} \mathrm{C}\right)$.

Tabela 1. Crescimento de Staphylococcus aureus em amostras de mexilhão in natura e submetidos à pré-cocção, após inoculação a temperatura ambiente $\left(25^{\circ} \mathrm{C} \pm 1^{\circ} \mathrm{C}\right)$ e sob refrigeração $\left(7^{\circ} \mathrm{C} \pm 1^{\circ} \mathrm{C}\right)$

\begin{tabular}{|c|c|c|c|}
\hline & \multirow{2}{*}{ Inicial $^{1}$} & \multicolumn{2}{|c|}{ Após 10 horas de incubação } \\
\hline & & Ambiente $\left(25^{\circ} \mathrm{C} \pm 1^{\circ} \mathrm{C}\right)$ & Refrigerado $\left(7^{\circ} \mathrm{C} \pm 1^{\circ} \mathrm{C}\right)$ \\
\hline & \multicolumn{3}{|c|}{ Mexilhão in natura ${ }^{1}$} \\
\hline Amostra 1 & $5,0 \times 10^{3}$ & $2,5 \times 10^{5}$ & $1,0 \times 10^{4}$ \\
\hline Amostra 2 & $6,0 \times 10^{3}$ & $4,0 \times 10^{5}$ & $2,0 \times 10^{4}$ \\
\hline Amostra 3 & $3,0 \times 10^{3}$ & $3,0 \times 10^{5}$ & $1,0 \times 10^{4}$ \\
\hline \multirow[t]{2}{*}{ Média } & $4,6 \times 10^{3}$ & $3,2 \times 10^{5}$ & $1,3 \times 10^{4}$ \\
\hline & \multicolumn{3}{|c|}{ Mexilhão cozido $^{1}$} \\
\hline Amostra 1 & $5,6 \times 10^{4}$ & $5,3 \times 10^{7}$ & $1,7 \times 10^{5}$ \\
\hline Amostra 2 & $6,0 \times 10^{4}$ & $6,1 \times 10^{7}$ & $1,3 \times 10^{5}$ \\
\hline Amostra 3 & $6,4 \times 10^{4}$ & $5,8 \times 10^{7}$ & $1,7 \times 10^{5}$ \\
\hline Média & $6,0 \times 10^{4}$ & $5,7 \times 10^{7}$ & $1,6 \times 10^{5}$ \\
\hline
\end{tabular}

${ }^{1}$ médias em duplicata, expressas em UFC $g^{-1}$ de carne

Pode-se observar na Tabela 1, que em ambos os tratamentos, in natura e submetidos à pré-cocção, houve crescimento microbiano, nos mexilhões 
mantidos a temperatura ambiente $\left(25^{\circ} \mathrm{C} \pm 1^{\circ} \mathrm{C}\right)$ ou sob refrigeração $\left(7^{\circ} \mathrm{C} \pm 1^{\circ} \mathrm{C}\right) . \mathrm{O}$ maior crescimento de $S$. aureus observado aconteceu no mexilhão cozido, mantido a temperatura ambiente, onde após 10 horas de incubação a $25^{\circ} \mathrm{C}$ $\left( \pm 1^{\circ} \mathrm{C}\right)$, obteve-se contagem da ordem de 5,3 a 6,1 x $10^{7}$ UFC $\mathrm{g}^{-1}$ de mexilhão, verificando-se um aumento de 3 ciclos logarítmicos.

Esse é um aspecto importante, uma vez que o $S$. aureus está relacionado com intoxicações alimentares e a enterotoxina ingerida é préelaborada em substratos alimentícios em densidade populacional situada entre $10^{6}-10^{8}$ UFC $\mathrm{g}^{-1}$. A ingestão de alimentos contaminados com S. aureus é a terceira causa mais freqüente de intoxicações alimentares, e, freqüentemente, está envolvido com problemas relacionados a gastroenterites, provocadas por alimentos de origem animal (Silva, 2000).

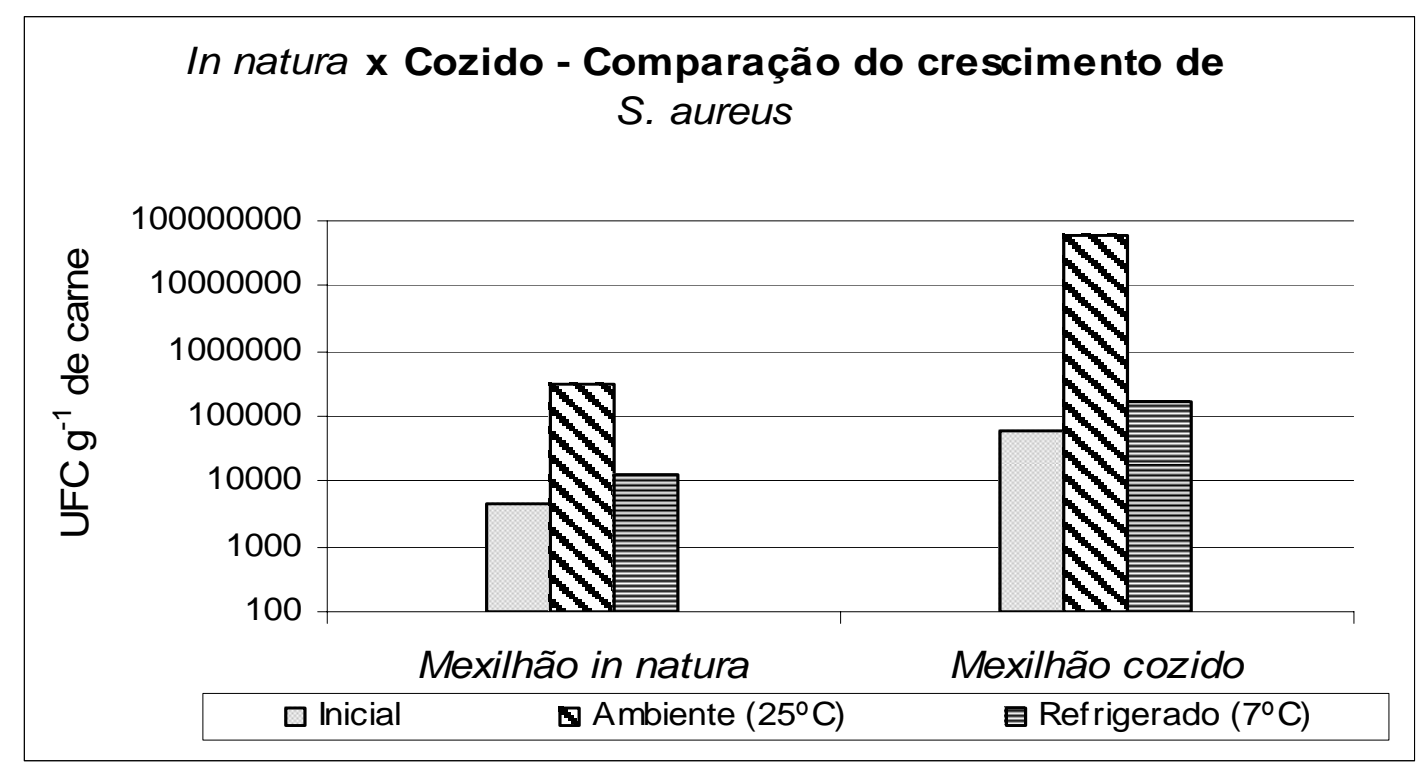

Figura 7 - Crescimento do Staphylococcus aureus em mexilhões in natura e submetidos à pré-cocção, mantidos a temperatura ambiente $\left(25^{\circ} \mathrm{C} \pm 1^{\circ} \mathrm{C}\right)$ e sob refrigeração $\left(7^{\circ} \mathrm{C} \pm 1^{\circ} \mathrm{C}\right)$.

Comportamento distinto do visto para o $S$. aureus, pode ser observado na Tabela 2 e na Figura 8, para o B. cereus, inoculado em mexilhões in natura e 
submetidos à pré-cocção, mantidos a temperatura ambiente $\left(25^{\circ} \mathrm{C} \pm 1^{\circ} \mathrm{C}\right)$ e sob refrigeração $\left(7^{\circ} \mathrm{C} \pm 1^{\circ} \mathrm{C}\right)$.

Tabela 2. Crescimento de Bacillus cereus em amostras de mexilhão in natura e submetidos à pré-cocção, mantidos a temperatura ambiente $\left(25^{\circ} \mathrm{C} \pm 1^{\circ} \mathrm{C}\right)$ e sob refrigeração $\left(7^{\circ} \mathrm{C} \pm 1^{\circ} \mathrm{C}\right)$

\begin{tabular}{lccc}
\hline & Inicial & \multicolumn{2}{c}{ Após 10 horas de incubação } \\
\cline { 3 - 4 } & & \multicolumn{3}{c}{ Mexilhão in natura ${ }^{1}$} \\
\hline Amostra 1 & $4,0 \times 10^{3}$ & $3,1 \times 10^{4}$ & $4,0 \times 10^{3}$ \\
Amostra 2 & $6,0 \times 10^{3}$ & $3,0 \times 10^{4}$ & $5,0 \times 10^{3}$ \\
Amostra 3 & $5,0 \times 10^{3}$ & $3,1 \times 10^{4}$ & $6,0 \times 10^{3}$ \\
Média & $5,0 \times 10^{3}$ & $3,1 \times 10^{4}$ & $5,0 \times 10^{3}$ \\
\hline & & Mexilhão cozido ${ }^{1}$ & \\
\hline Amostra 1 & $2,0 \times 10^{4}$ & $6,6 \times 10^{8}$ & $5,3 \times 10^{4}$ \\
Amostra 2 & $2,1 \times 10^{4}$ & $4,5 \times 10^{8}$ & $4,3 \times 10^{4}$ \\
Amostra 3 & $1,8 \times 10^{4}$ & $7,0 \times 10^{8}$ & $5,6 \times 10^{4}$ \\
\hline Média & $1,9 \times 10^{4}$ & $6,0 \times 10^{8}$ & $5,0 \times 10^{4}$ \\
\hline
\end{tabular}

${ }^{1}$ médias em duplicata, expressas em UFC $\mathrm{g}^{-1}$ de carne

Analisando-se a Tabela 2, observa-se que os mexilhões refrigerados, tanto in natura quanto cozidos, mantiveram níveis baixos de contagens, da

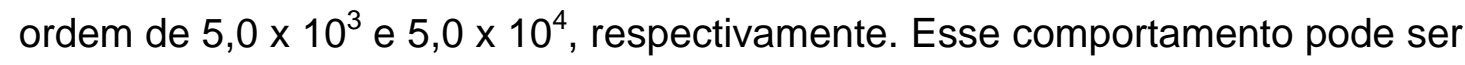
explicado, pelo fato do $B$. cereus apresentar dificuldades de crescimento em baixas temperaturas.

Johnson et al. (1983), observaram que em caldo tripticase-soja, o crescimento de $B$. cereus ocorre entre 15 e $50^{\circ} \mathrm{C}$, estando o ótimo na faixa de 35 a $40^{\circ} \mathrm{C}$. Mead et al. (2000), apresentam possibilidade de crescimento na faixa de 4 a $50^{\circ} \mathrm{C}$, para este microrganismo. 
Nos mexilhões in natura, mantidos à temperatura ambiente, observou-se um crescimento de 1 ciclo logarítmico, após as 10 horas de incubação. Já, para mexilhões cozidos e mantidos a temperatura ambiente $\left(25^{\circ} \mathrm{C} \pm 1^{\circ} \mathrm{C}\right)$, observou-se grande crescimento microbiano, de $10^{4}$ para $10^{8}$.

Esse é um dado importante, com relação à produção de esporos, tendose em vista que, para desencadear uma gastroenterite alimentar são necessários de $10^{7}$ a $10^{8}$ células por grama de alimento (Forsythe, 2002).

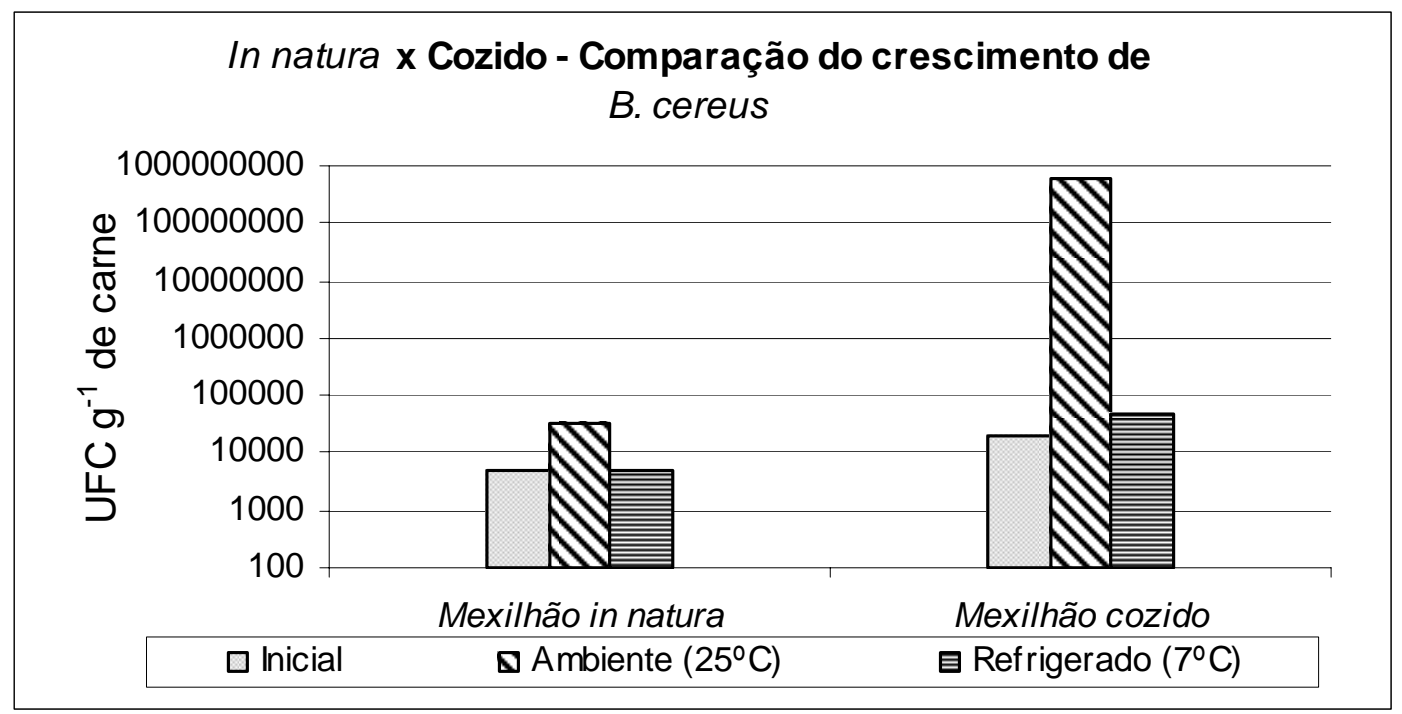

Figura 8 - Crescimento de Bacillus cereus em amostras de mexilhão in natura e submetidos à pré-cocção, mantidos a temperatura ambiente $\left(25^{\circ} \mathrm{C} \pm 1^{\circ} \mathrm{C}\right)$ e sob refrigeração $\left(7^{\circ} \mathrm{C} \pm 1^{\circ} \mathrm{C}\right)$

Como observado nesta pesquisa, Ola \& Oladipo (2004), estudando o tempo de armazenamento de corvina do Senegal (Pseudotholitus senegalensis) em gelo e a temperatura ambiente, observaram que a contagem total de microrganismos aumentou de $10^{3} \mathrm{UFC} \mathrm{g}^{-1}$ para $10^{6} \mathrm{UFC} \mathrm{g}^{-1}$, após 12 horas de armazenamento, já sendo rejeitada, sensorialmente, pelos consumidores. Neste estudo, foi observado também, que o gênero Bacillus foi o que mais contribuiu para esse aumento, tendo duplicado a sua contagem durante 0 
armazenamento. Já, quando se armazenou sob refrigeração, o Bacillus apresentou ligeira diminuição na contagem após os 20 dias de armazenamento.

Rawles et al. (1995), estudando o crescimento, sob refrigeração, de Listeria monocytogenes em carne de caranguejo azul cozida, obtiveram contagens de 7 ciclos logarítmicos, ao final de 21 dias de armazenamento refrigerado a $5^{\circ} \mathrm{C}$, sendo que, o crescimento se tornou mais pronunciado a partir do $10^{\circ}$ dia de armazenamento. Já Reily \& Hackney (1985), observando o crescimento de Vibrio cholerae em ostras contaminados por inoculação, e mantidas por 21dias sob armazenamento refrigerado $\left( \pm 7^{\circ} \mathrm{C}\right)$, obtiveram uma redução de 3 ciclos logaritmos nos 7 primeiros dias de armazenamento, mantendo-se as contagens inalteradas nos 14 dias seqüentes.

Neste estudo, a refrigeração mostrou ser um processo eficiente no controle do crescimento microbiano, para ambos os microrganismos. Este fato demonstra a importância de se refrigerar esse produto, principalmente, após o tratamento térmico, onde o produto sem as valvas, fica facilmente sujeito a contaminação.

A inoculação mostrou-se mais eficiente nos mexilhões submetidos à précocção para desconchagem do que nos mexilhões in natura, fato que demonstra a importância da concha na proteção dos mesmos quanto a contaminação microbiana.

A rápida deterioração na qualidade do pescado fresco é causada por atividades microbianas e de enzimas endógenas no animal post mortem. Normalmente, os métodos de preservação do pescado fresco objetivam controlar o crescimento microbiano (Simpson, 1997).

\subsection{Análises Microbiológicas - Tratamento Térmico}

$\mathrm{Na}$ Tabela 3 e na Figura 9, são apresentadas as médias das temperaturas atingidas ao final dos tempos de cocção, considerando-se as leituras de todas as amostras efetuadas no mesmo período de tratamento térmico. 
Tabela 3. Temperatura final atingida pelos 5 termopares nos tratamentos térmicos realizados ${ }^{1}$

\begin{tabular}{cccccc}
\hline Tratamentos térmicos $^{2}$ & \multicolumn{5}{c}{${\text { Temperatura }\left({ }^{\circ} \mathrm{C}\right)}$} \\
\hline Vapor por 5 min & 1 & 2 & 3 & 4 & 5 \\
\hline Vapor por 10 min & 95,65 & 96,14 & 72,25 & 64,27 & 11,69 \\
Vapor por 15 min & 99,35 & 98,64 & 99,15 & 98,47 & 11,79 \\
Imerso em água por 5 min & 98,95 & 99,04 & 98,15 & 96,47 & 11,89 \\
Imerso em água por 10 min & 97,95 & 98,14 & 94,65 & 89,37 & 10,09 \\
Imerso em água por 15 min & 97,05 & 98,24 & 98,45 & 97,57 & 11,19 \\
\hline
\end{tabular}

${ }^{1}$ média de 3 repetições; ${ }^{2}$ tempo medido após iniciar a ebulição

Pode-se verificar que todos os tratamentos térmicos atingiram temperaturas superiores a $60^{\circ} \mathrm{C}$, e que as diferenças registradas nesta faixa de temperatura entre os termopares, em um mesmo sistema não ultrapassou $10^{\circ} \mathrm{C}$, com exceção da cocção no vapor por $5 \mathrm{~min}$, fato que sugere uma distribuição uniforme do calor nas condições do experimento. Em estudos de tratamento térmico realizado por Antoniolli (1999), como observado nesta pesquisa, não ocorrem variações na distribuição do calor.

Segundo Pigott \& Tucker (1990), os microrganismos patogênicos são destruídos a temperaturas abaixo de $100^{\circ} \mathrm{C}$, sendo que, o efeito de aumentar a temperatura interna dos alimentos para $66^{\circ} \mathrm{C}$ é, normalmente, suficiente para tornar o alimento microbiologicamente seguro. 


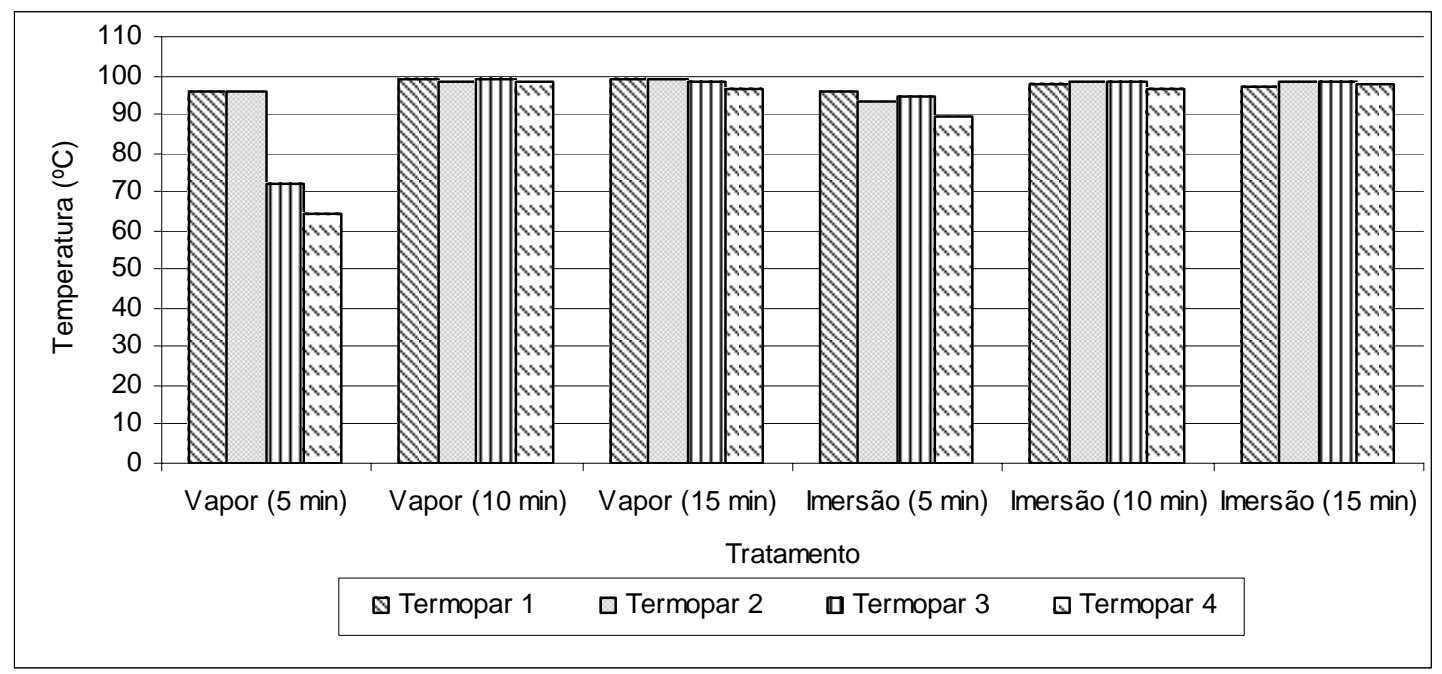

Figura 9 - Temperaturas medidas nos termopares, ao final do tempo de cocção

Essa constatação pode ser observada na Tabela 4 e na Figura 10, onde tem-se os valores do Número Mais Provável (NMP g ${ }^{-1}$ ) para Staphylococcus aureus e para Bacillus cereus em todos os tratamentos aplicados.

Analisando-se a Tabela 4, pode-se observar que os dois microrganismos apresentaram comportamentos semelhantes, sendo reduzidos em pelo menos 2 ciclos logarítmicos em todos os tratamentos utilizados. Constata-se que os tratamentos térmicos aplicados foram eficientes para reduzir, consideravelmente, os microrganismos inoculados.

Como relatado anteriormente, em todos os tempos de cocção atingiu-se, segundo os autores revisados, temperaturas suficientes para a redução no número dos microrganismos patogênicos de interesse à saúde pública. Podese notar, também, que os tratamentos com água a ebulição, foram mais eficientes na eliminação microbiana, se comparados aos tratamentos sob vapor. 
Tabela 4. Staphylococcus aureus (NMP g ${ }^{-1}$ ) e Bacillus cereus (NMP g $\mathrm{g}^{-1}$ ) em amostras de mexilhões, após inoculação e tratamento térmico ${ }^{1}$

\begin{tabular}{|c|c|c|c|c|}
\hline \multirow{2}{*}{$\begin{array}{c}\text { Tratamentos } \\
\text { térmicos }^{1}\end{array}$} & \multicolumn{3}{|c|}{ Amostra } & \multirow{2}{*}{ Média } \\
\hline & 1 & 2 & 3 & \\
\hline \multicolumn{5}{|c|}{ Staphylococcus aureus (NMP g ${ }^{-1}$ ) } \\
\hline Controle (In natura) & $1,1 \times 10^{5}$ & $1,1 \times 10^{5}$ & $1,1 \times 10^{5}$ & $1,1 \times 10^{5}$ \\
\hline \multicolumn{5}{|l|}{ Vapor } \\
\hline $5 \mathrm{~min}$ & $4,6 \times 10^{3}$ & $4,6 \times 10^{3}$ & $4,6 \times 10^{3}$ & $4,6 \times 10^{3}$ \\
\hline $10 \min$ & $4,3 \times 10^{1}$ & $6,4 \times 10^{1}$ & $6,4 \times 10^{1}$ & $5,7 \times 10^{1}$ \\
\hline $15 \min$ & $1,4 \times 10^{1}$ & $1,5 \times 10^{1}$ & $1,4 \times 10^{1}$ & $1,4 \times 10^{1}$ \\
\hline
\end{tabular}

Imersão em água à ebulição

\begin{tabular}{ccccc}
$5 \mathrm{~min}$ & $3,9 \times 10^{2}$ & $2,8 \times 10^{2}$ & $2,8 \times 10^{2}$ & $3,1 \times 10^{2}$ \\
$10 \mathrm{~min}$ & 7 & $1,1 \times 10^{1}$ & $1,1 \times 10^{1}$ & 9,6 \\
$15 \mathrm{~min}$ & 3 & 3 & 4 & 3,33 \\
\hline
\end{tabular}

Bacillus cereus (NMP g ${ }^{-1}$ )

\begin{tabular}{lllll}
\hline Controle (In natura) & $2,1 \times 10^{4}$ & $4,6 \times 10^{4}$ & $2,1 \times 10^{4}$ & $2,9 \times 10^{4}$
\end{tabular}

Vapor

$\begin{array}{lllll}5 \min & 9,3 \times 10^{2} & 9,0 \times 10^{1} & 2,8 \times 10^{2} & 4,3 \times 10^{2} \\ 10 \min & 7,5 \times 10^{1} & 6,4 \times 10^{1} & 2,8 \times 10^{1} & 5,6 \times 10^{1} \\ 15 \min & 9,5 \times 10^{1} & 2,8 \times 10^{1} & 2,8 \times 10^{1} & 5,0 \times 10^{1}\end{array}$

Imersão em água à ebulição

$\begin{array}{lllll}5 \min & 2,8 \times 10^{2} & 2,1 \times 10^{2} & 2,1 \times 10^{2} & 2,3 \times 10^{2} \\ 10 \min & 1,5 \times 10^{1} & 3,9 \times 10^{1} & 3,9 \times 10^{1} & 2,6 \times 10^{1} \\ 15 \min & 2,8 \times 10^{1} & 2,8 \times 10^{1} & 2,1 \times 10^{1} & 3,1 \times 10^{1}\end{array}$

1 média de 2 repetições; ${ }^{2}$ tempo medido após iniciar a ebulição

Antoniolli (1999), estudando a vida útil de mexilhões Perna perna processados e mantidos sob refrigeração, utilizou diferentes tempos de cocção, desde 15 até $30 \mathrm{~min}$, obtendo temperaturas finais que variaram de 80 a $96^{\circ} \mathrm{C}$ e observou que todos os tratamentos térmicos aplicados foram satisfatórios 
quanto à eliminação dos microrganismos. Já, Chai et al. (1994) estudaram o processo térmico para ostras e sugeriram o tratamento a $75-76^{\circ} \mathrm{C}$, por $8 \mathrm{~min}$, visando uma melhor qualidade do produto.
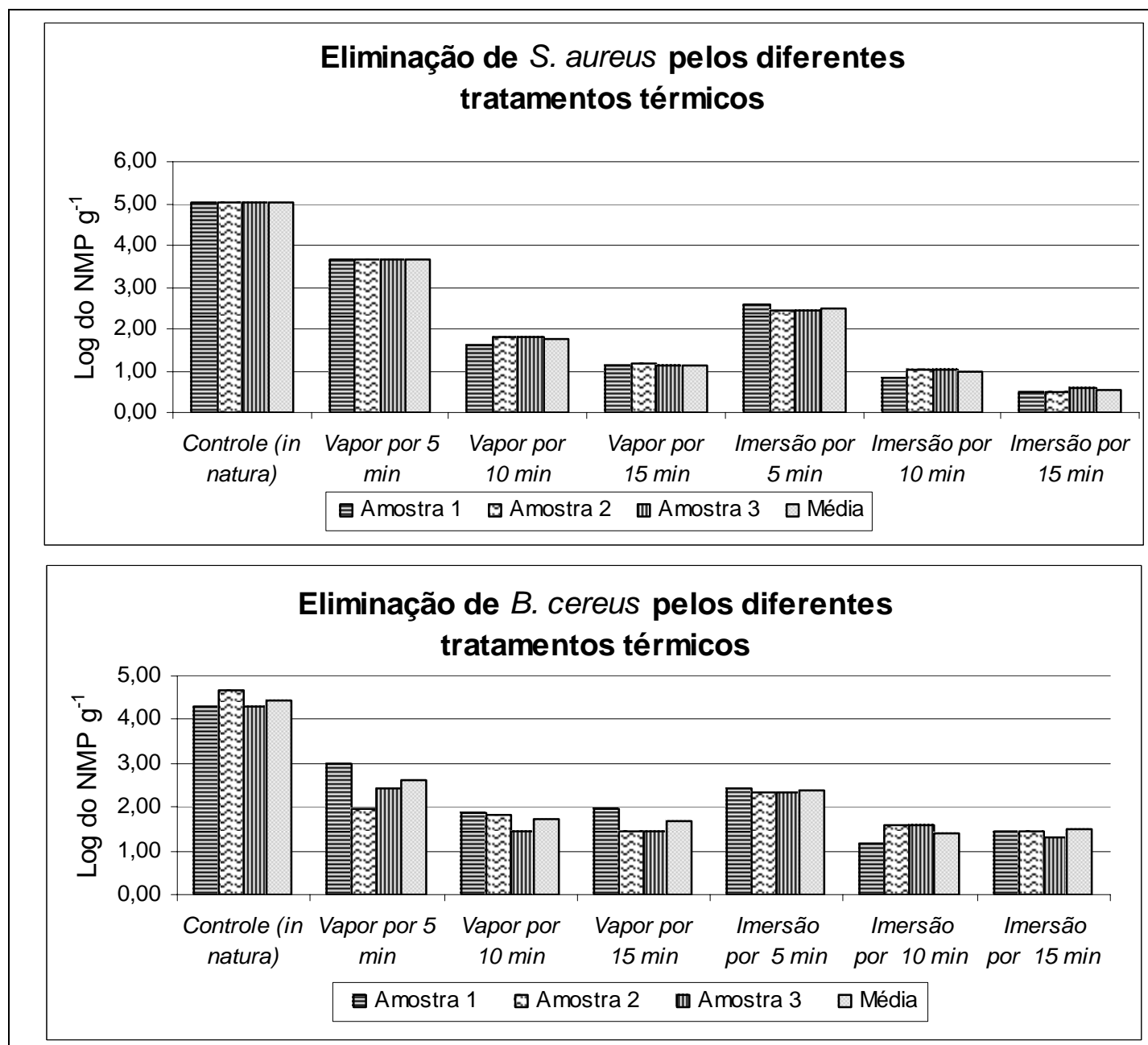

Figura 10 - Tratamentos térmicos para eliminação de Staphylococcus aureus e Bacillus cereus em amostras de mexilhões.

Outro modo de eliminar microrganismos foi estudado por Juneja et al. (1999), que demonstraram que a adição de $\mathrm{NaCl}$ age de forma protetora à E. coli O157:H7 contra o efeito letal do calor em carne bovina, em $\mathrm{pH} 4$. No 
entanto, com pH 8, esta tendência se inverte, onde a temperatura necessária para a redução decimal, aumentou conforme o teor crescente de sal.

Kotrola \& Conner (1997), também demonstraram que a sobrevivência de E. coli em carne de aves era significativamente aumentada (tempo de redução decimal maior) pelo uso de elementos aditivos no preparo da carne de peru, como lactato de sódio, sal e polifosfatos. Em todos os casos, a porcentagem de água diminuía, bem como a mobilidade de água no meio.

Ama et al. (1994), estudando os efeitos da temperatura e do $\mathrm{pH}$ na inativação de $V$. vulnificus, observaram que quando se tem contagens iniciais elevadas do microrganismo $\left(\sim 10^{7}\right.$ por $\mathrm{mL}$ ou $\left.\mathrm{g}\right)$, os tratamentos térmicos não são efetivos na eliminação deste. O mesmo foi observado por Schaffner et al. (1989) com S. enteriditis inoculado em ovo líquido inteiro, onde contagens iniciais menores propiciaram aumento na taxa de inativação por termoradiação a $60^{\circ} \mathrm{C}$.

Esta constatação é importante, pois apesar do tratamento térmico ser efetivo para eliminar microrganismos, o mesmo não deve ser utilizado com esta finalidade, principalmente, quando se tem uma matéria-prima de baixa qualidade.

\subsection{Análises físico-químicas e rendimento}

\subsubsection{Biometria}

A tabela 5, apresenta a biometria dos mexilhões, distribuídos nos tamanhos médio, máximo e mínimo. Pode-se observar que ao longo dos meses avaliados, não se obteve grandes variações no tamanho dos mexilhões, sendo os maiores valores encontrados, no ultimo mês de coleta. 
Tabela 5. Biometria dos mexilhões em função das coletas ${ }^{1}$

\begin{tabular}{lccc}
\hline & \multicolumn{3}{c}{ Tamanho (em cm) } \\
\hline Coletas $^{1}$ & Média & Mínimo & Máximo \\
\hline Novembro/2003 & 6,3 & 4,8 & 7,6 \\
Dezembro/2003 & 6,1 & 4,8 & 7,1 \\
Janeiro/2004 & 6,1 & 4,5 & 7,6 \\
Março/2004 & 6,8 & 5,4 & 7,8
\end{tabular}

${ }^{1}$ média de 200 valvas (100 indivíduos).

Neste mesmo projeto, em coletas realizadas nos meses de novembro de 2002 a março de 2003, observaram-se valores semelhantes para o tamanho dos mexilhões nos três pontos de coleta avaliados (Furlan, 2004).

O tamanho dos mexilhões pode ser diretamente relacionado à contagem microbiana apresentada pelo produto, uma vez que os mexilhões se alimentam por filtração, sendo esta realizada sem nenhuma capacidade seletiva e, dependente do tamanho do mexilhão, variando entre 19 a $50 \mathrm{~L} \mathrm{~h}^{-1}$. (Cook, 1991; Lira et al., 2000). Quanto menor o marisco, maior a sua capacidade de filtração, e, portanto, maior a sua concentração microbiana.

Segundo Quayle \& Newkirk (1989), o crescimento da concha é altamente dependente da temperatura; quando a temperatura da água é elevada o ano todo, o crescimento da concha ocorre de forma contínua.

Os mexilhões em Ubatuba, SP apresentam uma variação de tamanho entre 6,0 - 7,1 cm, após 9 meses de cultivo, se cultivados com sementes extraídas de bancos naturais (Assumpção, 1999). Marques (1998), relata que, no litoral paulista, os mexilhões costumam ser comercializados a partir dos $5 \mathrm{~cm}$ de comprimento, não sendo vantajoso para o produtor, esperar os animais atingirem tamanhos maiores para comercializá-los, já que o crescimento, praticamente, estabiliza aos $6 \mathrm{~cm}$, diferentemente do que ocorre em outros estados brasileiros. 
Segundo Henriques (2001), o crescimento e a produtividade de mexilhões, tanto de cultivo quanto de bancos naturais, dependem de diversas variáveis como a temperatura, a salinidade, a circulação da água, a densidade dos indivíduos, a quantidade e a qualidade de alimento disponível e a baixa incidência de parasitas, competidores e predadores.

\subsubsection{Composição centesimal e pH}

Os resultados obtidos para composição centesimal e pH do mexilhão in natura e cozido, nos diferentes tratamentos térmicos aplicados, estão apresentados na Tabela 6.

Nesta pesquisa, os valores médios encontrados para todos os tratamentos, não apresentaram diferença significativa, ao nível de 5\%, para todos os parâmetros avaliados nas análises fisico-químicas.

Tabela 6. Composição centesimal e pH do mexilhão submetidos à cocção por diferentes tratamentos térmicos

\begin{tabular}{ccccccc}
\hline $\begin{array}{c}\text { Tratamento } \\
\text { Térmico }^{1,2}\end{array}$ & Umidade & Proteína & Lipídeos & Cinza & Carboidratos & $p H$ \\
\hline $\begin{array}{c}\text { Controle } \\
\text { (In natura) }\end{array}$ & $82,82 \mathrm{a}^{3}$ & $11,78 \mathrm{a}$ & $1,55 \mathrm{a}$ & $2,37 \mathrm{a}$ & $1,98 \mathrm{a}$ & $6,46 \mathrm{a}$ \\
Vapor & & & & & & \\
$5 \mathrm{~min}$ & $79,85 \mathrm{a}$ & $15,01 \mathrm{a}$ & $1,79 \mathrm{a}$ & $2,03 \mathrm{a}$ & $1,32 \mathrm{a}$ & $6,87 \mathrm{a}$ \\
$10 \mathrm{~min}$ & $75,57 \mathrm{a}$ & $17,52 \mathrm{a}$ & $2,33 \mathrm{a}$ & $2,05 \mathrm{a}$ & $2,53 \mathrm{a}$ & $6,97 \mathrm{a}$ \\
$15 \mathrm{~min}$ & $75,13 \mathrm{a}$ & $17,34 \mathrm{a}$ & $2,57 \mathrm{a}$ & $2,01 \mathrm{a}$ & $2,95 \mathrm{a}$ & $7,07 \mathrm{a}$
\end{tabular}

Imersão em água à ebulição

$\begin{array}{crrrrrr}5 \text { min } & 80,03 \text { a } & 14,73 \text { a } & 2,03 \text { a } & 1,49 \text { a } & 1,72 \text { a } & 6,92 \text { a } \\ 10 \text { min } & 77,11 \text { a } & 16,80 \text { a } & 2,61 \text { a } & 1,61 \text { a } & 1,87 \text { a } & 7,08 \text { a } \\ 15 \text { min } & 76,23 \text { a } & 16,59 \text { a } & 2,81 \text { a } & 1,56 \text { a } & 2,81 \text { a } & 7,11 \text { a } \\ { }^{1} \text { média de } 3 \text { repetições; }{ }^{2} \text { tempo medido após iniciar a ebulição; }{ }^{3} \text { letras iguais } \\ \text { não diferem estatisticamente entre si (p<0,05) }\end{array}$


Mesmo não havendo diferença estatística, pode-se observar, todavia, que os valores de umidade e cinza decresceram com os tratamentos térmicos, o que indica uma ligeira exsudação - perda de água e de minerais, em todos os tratamentos. Para os demais atributos, pode-se observar um ligeiro acréscimo dos teores com o aumento do tempo de cocção, resultante da perda de água.

Para o mexilhão in natura, obteve-se valores médios de 82,82; 11,78; 1,55 e 2,37 g $100 \mathrm{~g}^{-1}$, respectivamente, para umidade, proteína, lipídeos e cinza. Estes dados estão de acordo com várias tabelas de composição de alimentos, como a tabela da Associação Catarinense de Aqüicultura - ACAQ (2004), que para o mesmo marisco estudado nesta pesquisa apresenta valores de 83,$00 ; 12,00 ; 1,5 ; 1,9$ e 3,00 g $100 \mathrm{~g}^{-1}$, respectivamente, para os mesmos parâmetros, e a tabela de Franco (2004), que obteve valores de 14,40 e 2,30 $100 \mathrm{~g}^{-1}$, respectivamente, para proteína e lipídeos.

Pedrosa \& Cozzolino (2001), avaliando a composição centesimal de mexilhão da espécie Anomalocardia brasiliana, encontraram valores para

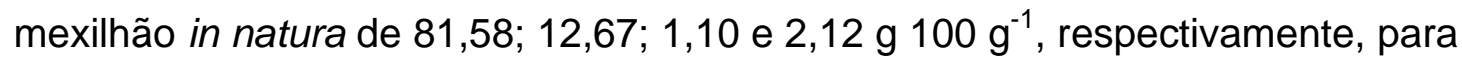
umidade proteína, lipídeos e cinza. Já Bindu et al. (2002), observando a composição nutricional de mexilhões Perna viridis in natura, encontraram valores de 76,69 g $100 \mathrm{~g}^{-1}$ para umidade, 2,57 g $100 \mathrm{~g}^{-1}$ para lipídeos,

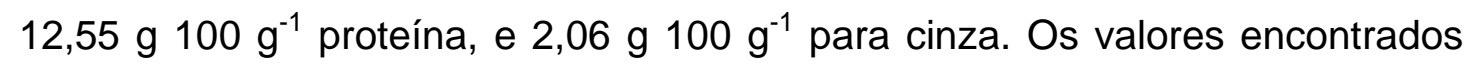
nesta pesquisa estão próximos aos encontrados nestes estudos.

Valores diferentes aos encontrados nesta pesquisa foram apresentados por Tavares et al. (1998), que avaliando a variação da composição de mexilhões Perna perna, ao longo do ano, em Ubatuba/SP, obtiveram valores inferiores para umidade $\left(72,12 \mathrm{~g} 100 \mathrm{~g}^{-1}\right)$, e superiores para proteína (20,5 g $\left.100 \mathrm{~g}^{-1}\right)$ e lipídeos (3,24 g $\left.100 \mathrm{~g}^{-1}\right)$.

Pesquisando a composição nutricional da pata de caranguejo verde (Carcinus maenus), Skonberg \& Perkins (2002), não observaram diferença na composição centesimal da pata crua e da pata cozida por doze minutos no vapor, como observado nesta pesquisa para o mexilhão. 
Os resultados obtidos nesta pesquisa, porém, são diferentes dos obtidos por Kyriazi-Papadopoupou et al. (2003), que observaram em mexilhões Mytilus galloprovincialis, uma redução na composição centesimal dos mexilhões submetidos à cocção de $10 \mathrm{~min}$, sob vapor $\left(80^{\circ} \mathrm{C}\right)$. Já Gokoglu et al. (2004), estudando os efeitos de diferentes métodos de cocção na composição centesimal e no conteúdo de minerais de trutas arco-íris (Oncorhynchus mykiss), observaram que trutas cozidas em água à ebulição por 5 min, não apresentam diferença significativa nos teores de proteína e gordura, porém apresentaram valores de umidade e cinza reduzidos.

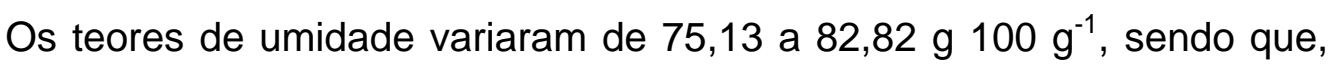
quanto mais intenso o tratamento térmico, menores os valores de umidade. Valores semelhantes aos encontrados nessa pesquisa, podem ser encontrados nas pesquisas de Schramm (1993) que obteve teores de umidade entre 75 e $82 \mathrm{~g} 100 \mathrm{~g}^{-1}$, para mexilhões pré-cozidos em água à ebulição por 5 min, e Magalhães (1985), que obteve valores entre 78,30 e 89,77 g $100 \mathrm{~g}^{-1}$ para mexilhões in natura.

Os teores protéicos, encontrados neste trabalho, variaram de 11,78 a

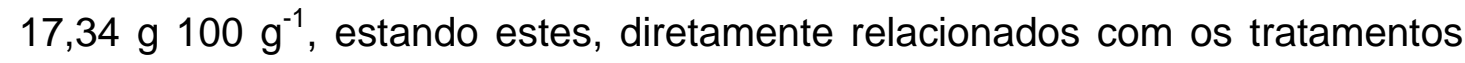
térmicos aplicados. Os maiores teores de proteína foram observados nos tratamentos com maior tempo de exposição à alta temperatura e nos tratamentos com exposição ao vapor. Os dados encontrados, são superiores aos apresentados por Gelli (1992), de 6,7 a 9,5 g $100 \mathrm{~g}^{-1}$. Este fato pode ter ocorrido devido a diversos fatores como região de coleta dos animais, diferentes estádios de reprodução e metodologias utilizadas (Magalhães 1985). Em estudos realizados por Lema et al. (1986), foi observado que a cocção não só melhora o valor nutricional dos mexilhões, como também desnatura e hidrolisa a proteína, facilitando assim a degradação e a digestão das mesmas durante o processo digestivo.

Para lipídeos, obtiveram-se valores desde 1,55 g $100 \mathrm{~g}^{-1}$, para 0 mexilhão in natura, até $2,81 \mathrm{~g} 100 \mathrm{~g}^{-1}$, nos submetidos ao tratamento por 
imersão, em água a ebulição, por 15 min Segundo Ackman (1999), o conteúdo de lipídeos dos mariscos varia entre 1 e $2 \mathrm{~g} 100 \mathrm{~g}^{-1}$, sendo este reduzido teor lipídico relacionado ao armazenamento da energia na forma de glicogênio, pelos bivalves.

Os valores de $\mathrm{pH}$ encontrados neste trabalho variaram de 6,46 a 7,11, sendo observado um aumento crescente do $\mathrm{pH}$, quanto mais intenso foi o método de cocção, não importando, no entanto, o modo como essa cocção foi conduzida. Este dados estão semelhantes aos encontrados por Oetterer (2003), para mexilhões Perna perna coletados em Ubatuba, que, segundo a autora, variaram de 5,8 a 6,9 em mexilhões in natura.

As amônias e aminas provocam uma elevação no pH durante a deterioração de peixes cartilaginosos e crustáceos. Porém, a presença de níveis significantes de carboidratos em moluscos bivalves, em princípio, conduz para atividades de sacarificação e a acumulação de ácidos orgânicos, resultando numa diminuição no pH durante a deterioração (ICMSF, 1998).

O potencial hidrogeniônico é um método de determinação da acidez de um produto alimentício, e, principalmente, no caso de pescado, que tem uma acidez baixa, pode fornecer um dado valioso sobre seu estado de conservação. O processo de decomposição altera, quase sempre, a concentração de íons hidrogênio de um alimento (Brasil, 1980; Tavares et al., 1988).

\subsubsection{Minerais}

As perdas de minerais pelos diferentes processos de cocção dos mexilhões, estão presentes na Tabela 7.

Os dados da literatura para minerais em mexilhões são escassos, sendo poucos os minerais analisados, o que torna difícil uma análise comparativa entre os dados obtidos neste estudo. 
Tabela 7. Minerais em mexilhão submetido à cocção por diferentes tratamentos térmicos

\begin{tabular}{|c|c|c|c|c|c|}
\hline \multirow{2}{*}{$\begin{array}{c}\text { Tratamentos } \\
\text { Térmicos }^{1,2}\end{array}$} & \multicolumn{5}{|c|}{ Minerais } \\
\hline & Fósforo & Potássio & Cálcio & Magnésio & Enxofre \\
\hline & \multicolumn{5}{|c|}{ g $100 g^{-1}$} \\
\hline Controle (in natura) & $0,91 b^{3}$ & $1,20 \mathrm{a}$ & $0,46 a$ & $0,52 \mathrm{a}$ & $0,84 \mathrm{a}$ \\
\hline \multicolumn{6}{|l|}{ Vapor } \\
\hline $5 \mathrm{~min}$ & $0,99 \mathrm{~b}$ & $1,06 \mathrm{a}$ & $0,25 b$ & $0,49 a$ & $0,83 \mathrm{a}$ \\
\hline $10 \mathrm{~min}$ & $1,06 \mathrm{a}$ & $0,80 \quad b$ & $0,33 \mathrm{~b}$ & $0,45 a$ & $0,77 \mathrm{a}$ \\
\hline $15 \mathrm{~min}$ & $1,04 \mathrm{a}$ & $0,70 \quad b$ & $0,35 \mathrm{~b}$ & $0,45 \mathrm{a}$ & $0,76 \mathrm{a}$ \\
\hline
\end{tabular}

Imersão em água à ebulição

\begin{tabular}{|c|c|c|c|c|c|c|}
\hline $5 \mathrm{~min}$ & $1,14 \mathrm{a}$ & 0,69 & $b$ & $0,40 \mathrm{a}$ & $0,42 \quad b$ & $0,75 a$ \\
\hline $10 \mathrm{~min}$ & $1,03 \mathrm{a}$ & 0,56 & $b$ & $0,32 \quad b$ & $0,39 b$ & $0,75 a$ \\
\hline \multirow[t]{2}{*}{$15 \min$} & $1,13 \mathrm{a}$ & 0,60 & $b$ & $0,41 \mathrm{a}$ & $0,41 \quad b$ & $0,74 \mathrm{a}$ \\
\hline & Boro & Cobre & & Ferro & Manganês & Zinco \\
\hline & \multicolumn{6}{|c|}{$\mathrm{mg} 100 \mathrm{~g}^{-1}$} \\
\hline Controle (in natura) & $2,15 \mathrm{a}$ & 0,89 & $b$ & $47,53 \quad b$ & 0,80 & $10,57 \quad b$ \\
\hline \multicolumn{7}{|l|}{ Vapor } \\
\hline $5 \mathrm{~min}$ & $1,47 \quad b$ & 0,83 & $b$ & $43,11 \quad b$ & 0,55 & 9,59 \\
\hline $10 \min$ & $1,36 \quad b$ & $1,15 \mathrm{a}$ & & $50,62 \quad b$ & $1,10 \mathrm{a}$ & 10,94 a \\
\hline $15 \min$ & $1,13 \quad b$ & $1,21 \mathrm{a}$ & & $53,34 \mathrm{a}$ & $1,41 \mathrm{a}$ & $11,29 \mathrm{a}$ \\
\hline
\end{tabular}

Imersão em água à ebulição

$\begin{array}{lllllll}5 \mathrm{~min} & 1,13 & \mathrm{~b} & 1,08 \mathrm{a} & 60,53 \mathrm{a} & 1,12 \mathrm{a} & 11,08 \mathrm{a} \\ 10 \mathrm{~min} & 1,55 & \mathrm{~b} & 1,05 \mathrm{a} & 52,42 \mathrm{a} & 1,08 \mathrm{a} & 11,02 \mathrm{a} \\ 15 \mathrm{~min} & 1,53 & \mathrm{~b} & 1,11 \mathrm{a} & 57,65 \mathrm{a} & 1,13 \mathrm{a} & 11,57 \mathrm{a}\end{array}$

${ }^{1}$ média de 3 repetições; ${ }^{2}$ tempo medido após iniciar a ebulição; ${ }^{3}$ letras iguais não diferem estatisticamente entre si $(p<0,05)$

Os teores encontrados nesta pesquisa para mexilhão in natura, são semelhantes aos encontrados por Karakoltsidis, Zotos e Constatinidos (1995), 
para potássio, cálcio, magnésio, cobre e manganês; e superiores para ferro e zinco, em mexilhões da espécie Mytilus galloprovinciallis.

Os valores encontrados para fósforo $\left(0,91\right.$ a 1,13 g $\left.100 \mathrm{~g}^{-1}\right)$ e potássio (0,56 a 1,20 g $\left.100 \mathrm{~g}^{-1}\right)$, cálcio (0,46 a 0,25 g $\left.100 \mathrm{~g}^{-1}\right)$, magnésio (0,39 a 0,52 $\left.\mathrm{g} 100 \mathrm{~g}^{-1}\right)$ e ferro (43,11 a 60,53 mg $\left.100 \mathrm{~g}^{-1}\right)$, estão acima dos encontrados por Franco (2004) e pela ACAQ (2004), para mexilhões Perna perna .

A quantidade de minerais presentes nos mexilhões, é influenciada por diversos fatores, tais como estádio reprodutivo, região de coleta e época do ano. Estes fatores impedem que se faça comparações pontuais, a não ser que todas as variáveis sejam consideradas na pesquisa.

Observando-se a Tabela 7, pode-se constatar que dos minerais analisados, apenas o boro apresentou redução significativa, em todos os tratamentos térmicos aplicados, e que apenas no caso do enxofre, a cocção não influenciou no conteúdo.

Alguns minerais apresentaram ligeira redução dos teores, dependendo dos tratamentos térmicos aplicados. O potássio, apresentou redução significativa quanto maior o tempo de exposição a altas temperaturas. Já o cálcio, demonstrou uma perda mais acentuada nos tratamentos sob vapor do que nos sob imersão.

Pode-se observar que teor de magnésio sofreu um decréscimo com os tratamentos em imersão em água, porém não se alteraram nos tratamentos de 5 e 10 min sob vapor. Este mesmo efeito foi observado por Skonberg \& Perkins (2002), que estudando a composição nutricional da pata de caranguejo verde (Carcinus maenus), não obtiveram diferença no teor de magnésio, utilizando um tratamento de 12 min sob vapor.

Esta diminuição dos teores pode ser explicada pela presença de compostos solúveis complexantes, ou mesmo na forma livre, que poderiam ser perdidos pela água de cocção.

Dos demais minerais, alguns apresentaram acréscimo nos teores, como o fósforo, o cobre, o manganês e o zinco, que apresentaram teores maiores 
quanto maior o tempo de exposição ao calor. Os dados sugerem que a cocção pode ter influído aumentando os teores destes minerais das amostras de duas maneiras: pela perda de umidade, concentrando este mineral no alimento; ou pela presença de compostos ligantes dos minerais no alimento, que impediram sua perda pela água de cocção.

Diferente dos dados encontrados nesta pesquisa, Pedroza \& Cozzolino (2001), obtiveram para mexilhão cozidos em água por 35 min, uma perda ao redor de 50\% no teor de zinco. Nesta mesma pesquisa, observaram aumento nos teores para camarão e ostra, e não obtiveram diferença no conteúdo para caranguejo e lagosta.

Ainda segundo Pedroza \& Cozzolino (2001), o mexilhão apresenta-se como um alimento rico em cobre, sendo que a cocção ocasionou perdas de $50 \%$ com o tratamento térmico de 35 min em água. Já nos nesta pesquisa, a cocção influenciou positivamente, provocando aumento no conteúdo deste mineral, em todos os tratamentos utilizados.

No caso do ferro, obteve-se um aumento no conteúdo, com relação à forma de cocção aplicada. Nos tratamentos sob imersão, obtiveram-se teores de ferro maior que os tratamentos sob vapor, sendo que o tratamento de 5 min sob imersão em água fervente, foi o que apresentou maior teor deste mineral.

Com relação ao teor de ferro, Pedroza \& Cozzolino (2001), constataram que dentre os mariscos estudados que os moluscos apresentaram as maiores concentrações de ferro, ocupando o primeiro lugar o mexilhão, seguido da ostra. Diferentemente do encontrado nesta pesquisa, a cocção influiu na composição do mexilhão, diminuindo o teor de ferro encontrado.

\subsubsection{Rendimento}

Os valores obtidos para o rendimento da parte comestível e do peso total dos mexilhões submetidos a diferentes tratamentos térmicos, são apresentados na Tabela 8 e na Figura 11. 
Tabela 8. Rendimento da parte comestível e peso total, em \%, de mexilhões submetidos a diferentes tratamentos térmicos

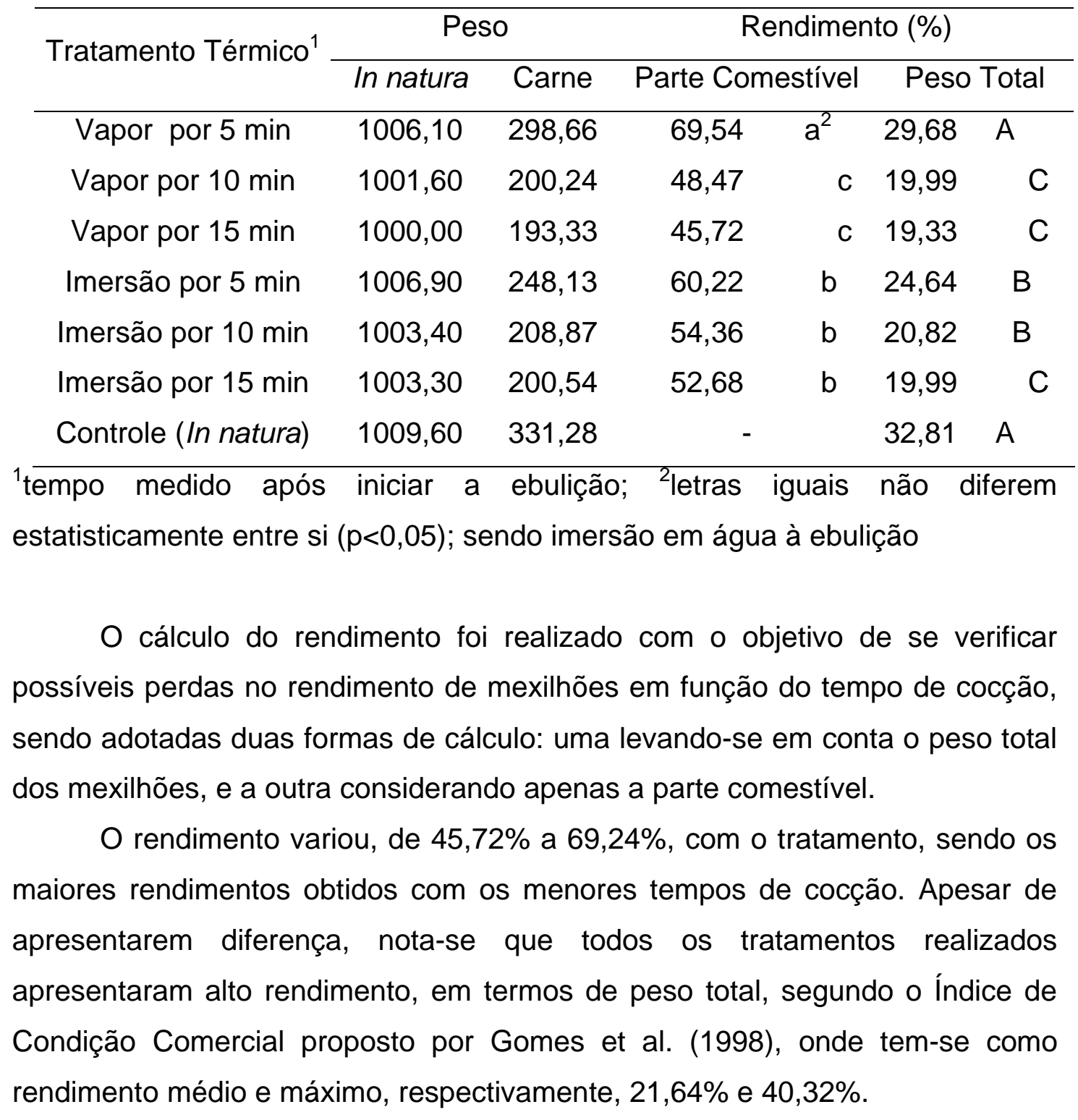




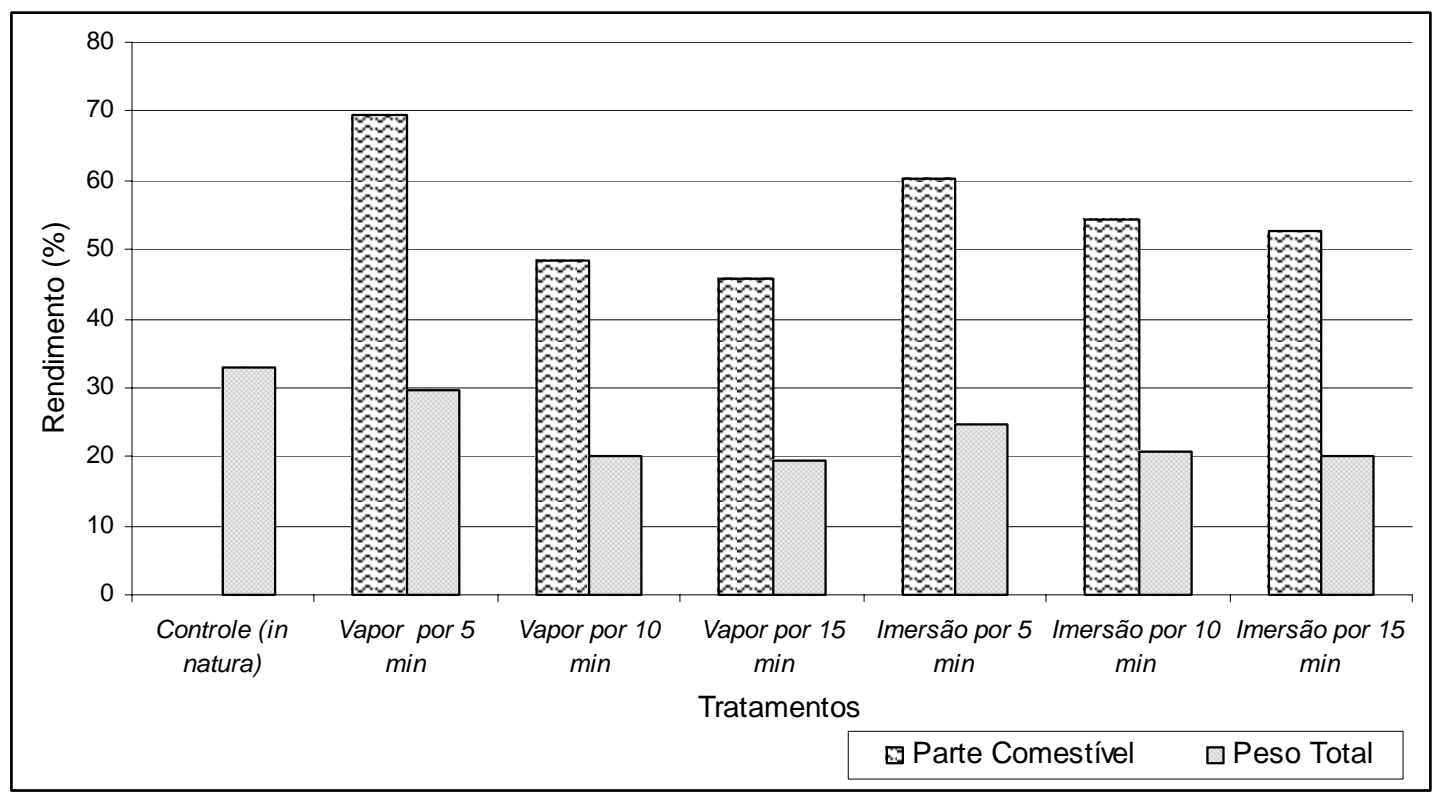

Figura 11 - Rendimento da parte comestível e peso total (\%), de mexilhões submetidos a diferentes tratamentos térmicos

Os moluscos e crustáceos apresentam rendimentos mais baixos que os dos peixes. O rendimento em carne, útil para industrialização (congelados, enlatados, salgados), é fortemente afetado pelo tipo de concha ou de carapaça que, por sua vez, varia de acordo com o habitat e o estado fisiológico (Contreras Guzmán, 1994).

De acordo com Antoniolli (1999), os registros de rendimento para o mexilhão Perna perna são escassos, dificultando, conseqüentemente, comparações com outras pesquisas. Em suas pesquisas, Antoniolli (1999), obteve rendimentos para o peso total e para a parte comestível, inferiores ao encontrados nesta pesquisa.

Em estudos realizados por Beirão (2002), foi encontrado valores de rendimento de aproximadamente $11 \%$ para a proporção casca/carne, valores estes que não podem ser comparados, pois a avaliação efetuou-se de forma diferenciada, uma vez que o autor avaliou apenas o peso do tecido. 


\subsection{Análise Sensorial}

A Figura 12 apresenta os resultados obtidos no teste de ordenação. Os valores foram obtidos enumerando-se de 1 a 4 as amostras de mexilhões, segundo a ordenação dada às amostras por cada provador, sendo considerado o valor 1 para a pior amostra e 4 para a melhor.

Na Tabela 9, são calculadas as diferenças entre as soma das ordens (Figura 12), para cada amostra, sendo avaliadas estatisticamente pelo teste de Friedman, utilizando-se os dados da tabela de Newell \& MacFarlane (1987).

Tabela 9. Diferença entre as soma das ordens de cada amostra submetida ao teste de ordenação.

\begin{tabular}{lcccc}
\hline \multirow{2}{*}{$\begin{array}{c}\text { Tratamentos } \\
\text { térmicos }\end{array}$} & \multicolumn{3}{c}{ Vapor } & \multicolumn{3}{c}{ Imersão } \\
\cline { 2 - 5 } & 5 min & 10 min & 5 min & 10 min \\
\cline { 2 - 5 } & - & 0 & 1 & 9 \\
Vapor 5 min & - & - & 1 & 9 \\
Imersão 5 min & - & - & - & 10 \\
Imersão 10 min & - & - & - & - \\
\hline
\end{tabular}

Sendo a imersão em água à ebulição

O valor crítico para o nível de significância de 5\%, segundo a tabela de Newell \& MacFairlane, é de 34. Os resultados encontrados não apresentaram diferença significativa neste nível.

Os resultados obtidos neste estudo mostram que mesmo com o aumento do tempo do tratamento térmico, não ocorreram perdas sensoriais, sendo que o melhor tratamento na opinião dos provadores foi o tratamento de $10 \mathrm{~min}$ em água à ebulição. A utilização de água à ebulição, ou vapor, não influenciou o produto final, obtendo-se produtos de boa qualidade em ambos os tratamentos. 


\begin{tabular}{|c|c|c|c|c|c|c|c|c|c|}
\hline \multirow{3}{*}{ 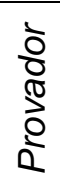 } & \multicolumn{4}{|c|}{ Tratamentos Térmicos } & \multirow{3}{*}{$\begin{array}{l}\bar{o} \\
\frac{0}{0} \\
\overline{0} \\
\bar{Q}\end{array}$} & \multicolumn{4}{|c|}{ Tratamentos Térmicos } \\
\hline & \multicolumn{2}{|c|}{ Vapor } & \multicolumn{2}{|c|}{ Imersão } & & \multicolumn{2}{|c|}{ Vapor } & \multicolumn{2}{|c|}{ Imersão } \\
\hline & $5 \min$ & $10 \mathrm{~min}$ & $5 \min$ & $10 \min$ & & $5 \min$ & $10 \mathrm{~min}$ & $5 \min$ & $10 \min$ \\
\hline 1 & $2^{1}$ & 4 & 1 & 3 & 26 & 4 & 2 & 3 & 1 \\
\hline 2 & 4 & 2 & 1 & 3 & 27 & 2 & 4 & 3 & 1 \\
\hline 3 & 1 & 2 & 3 & 4 & 28 & 1 & 2 & 4 & 3 \\
\hline 4 & 2 & 4 & 3 & 1 & 29 & 4 & 3 & 2 & 1 \\
\hline 5 & 1 & 3 & 2 & 4 & 30 & 4 & 1 & 2 & 3 \\
\hline 6 & 4 & 2 & 1 & 3 & 31 & 4 & 2 & 3 & 1 \\
\hline 7 & 4 & 1 & 2 & 3 & 32 & 4 & 3 & 2 & 1 \\
\hline 8 & 4 & 1 & 3 & 2 & 33 & 1 & 4 & 2 & 3 \\
\hline 9 & 3 & 4 & 1 & 2 & 34 & 1 & 3 & 4 & 2 \\
\hline 10 & 2 & 4 & 3 & 1 & 35 & 1 & 2 & 4 & 3 \\
\hline 11 & 4 & 2 & 3 & 1 & 36 & 2 & 1 & 4 & 3 \\
\hline 12 & 2 & 3 & 4 & 1 & 37 & 1 & 3 & 4 & 2 \\
\hline 13 & 2 & 4 & 1 & 3 & 38 & 2 & 3 & 4 & 1 \\
\hline 14 & 1 & 2 & 3 & 4 & 39 & 3 & 2 & 1 & 4 \\
\hline 15 & 4 & 2 & 3 & 1 & 40 & 2 & 1 & 3 & 4 \\
\hline 16 & 3 & 2 & 4 & 1 & 41 & 3 & 2 & 4 & 1 \\
\hline 17 & 3 & 1 & 2 & 4 & 42 & 2 & 1 & 4 & 3 \\
\hline 18 & 2 & 1 & 3 & 4 & 43 & 2 & 4 & 1 & 3 \\
\hline 19 & 3 & 4 & 1 & 2 & 44 & 1 & 2 & 4 & 3 \\
\hline 20 & 4 & 3 & 1 & 2 & 45 & 1 & 4 & 3 & 2 \\
\hline 21 & 3 & 4 & 1 & 2 & 46 & 4 & 1 & 3 & 2 \\
\hline 22 & 2 & 3 & 1 & 4 & 47 & 4 & 1 & 3 & 2 \\
\hline 23 & 3 & 1 & 4 & 2 & 48 & 1 & 4 & 3 & 2 \\
\hline 24 & 4 & 3 & 1 & 2 & 49 & 1 & 3 & 4 & 2 \\
\hline 25 & 2 & 3 & 1 & 4 & 50 & 3 & 4 & 1 & 2 \\
\hline & & & & & TAL & 127 & 127 & 128 & 118 \\
\hline
\end{tabular}

${ }^{1}$ Os números foram atribuídos em ordem decrescente (4 = mais gostou; 1 = menos gostou).

Figura 12 - Teste sensorial de ordenação entre os tratamentos térmicos. 
Segundo Gomes et al. (1998), nos mexilhões, as desovas representam uma variável significativa no peso e na depreciação do aspecto organoléptico do produto. Outro fator importante ligado ao local de cultivo, é a qualidade da água que, segundo Pigott e Tucker (1990), além de afetar a imagem do produto junto ao consumidor, pode provocar odor residual (off taste) nos mexilhões.

Em estudos realizados por Cambero et al. (1998), que observaram os efeitos das diferentes formas de cocção nos compostos aromáticos de caldo de camarão (Parapenaeus longirostris), obteve-se como melhor extrato de camarão, o tratamento a $55^{\circ} \mathrm{C}$ por 120 min, sendo que quando mais alta a temperatura aplicada, menores os tempos aplicados para se obter os melhores extratos, como, por exemplo, $95^{\circ} \mathrm{C}$ para 15 e $30 \mathrm{~min}$

Yasuhara \& Morita (1987) identificaram mais de 100 componentes voláteis em mexilhões (Mytilus edulis), entre os quais ésteres, ácidos, alcanos, e vários benzenos.

Guen et al. (2000), em estudos comparando três métodos olfativos para a identificação dos odores em mexilhão cozido, identificaram seis odores primários responsáveis pelo aroma do mexilhão, sendo o metional, o odor mais pronunciado, e semelhante ao odor de batata cozida. 


\section{CONCLUSÕES}

Através dos resultados encontrados nesta pesquisa, pode-se concluir que, ocorreu crescimento microbiano para $S$. aureus e B. cereus, tanto no mexilhão in natura como no mexilhão submetido à cocção, ao longo das 10 horas de observação.

O método de inoculação utilizado apresentou melhor efeito em mexilhões cozidos do que em mexilhões in natura, o que é explicado pela presença das valvas, que são uma proteção primária contra a contaminação externa.

Os mexilhões mantidos a temperatura ambiente $\left(25^{\circ} \mathrm{C} \pm 1^{\circ} \mathrm{C}\right)$, apresentaram crescimento microbiano mais pronunciado do que os armazenados sob refrigeração $\left(7^{\circ} \mathrm{C} \pm 1^{\circ} \mathrm{C}\right)$.

Todos os tratamentos térmicos aplicados apresentaram redução de, no mínimo 2 ciclos logarítmicos, para ambos os microrganismos, sendo que os tratamentos por imersão em água a ebulição foram mais eficientes na eliminação dos microrganismos do que os tratamentos sob vapor.

Nas análises fisico-químicas e sensorial, não se observou variação entre nenhum dos tratamentos térmicos aplicados, indicando que as temperaturas utilizadas e o modo como essas foram aplicadas não alteram as características do produto.

Pode-se observar diferenças na composição de minerais com relação ao tratamento térmico, o que evidencia as perdas de alguns nutrientes, como potássio e boro, com o emprego de altas temperaturas por um determinado período. 
Com relação ao rendimento, pode-se constatar que quanto menor o tempo de exposição ao calor maior o rendimento, sendo que nos tratamentos sob imersão, esse rendimento foi maior, se comparados aos tratamentos sob vapor.

Nas condições analisadas, o tratamento por imersão em água à ebulição por 10 min, foi eficiente para conferir segurança ao mexilhão podendo ser recomendado como prática á ser divulgada entre os mitilicultores. Este tratamento apresentou os melhores resultados quanto aos atributos sensoriais e rendimento. 


\section{REFERÊNCIAS BIBLIOGRÁFICAS}

ACKMAN, R.G. Composition y valor nutritivo de los lipídios del pescado y del marisco. In: RUITER, A. El pescado y los productos derivados de la pesca: composición, propriedades nutritivas y estabilidad. Zaragoza: Acribia, 1999. cap. 4, p. 81-121.

ADAMS, A.M.; LEJA, L..L.; JINNEMAN, K.; BEEH, J.; COOK, D.W.Anisakid parasites, Staphylococcus aureus and Bacillus cereus in sushi and sashimi form Seattle area restaurants. Jounal of Food Protection, v. 57, n. 4, p. 311-317, 1994.

AGÊNCIA NACIONAL DA VIGILÂNCIA SANITÁRIA - ANVISA. Resolução RDC n'12, de janeiro de 2001. Regulamento Técnico sobre padrões microbiológicos em Alimentos. http://www.anvisa.gov.br/legis/resol/ (15/05/2004).

AMA, A.A.; HAMDY, M.K.; TOLEDO, R.T. Effects of heating, $\mathrm{pH}$ and thermoradiation on inactivation of $V$. vulnificus. Food Microbiology, v. 11, n. 1, p. 215-227, 1994.

ANDERSON, B.A.; LAUDERDALE, J.L.; HOKE, I.M. Composition of foods: beef prodcuts. Washington: USDA, 1986. (Revision USDA Agriculture Handbook. $n^{\circ} 8-13$ ) 
ANDREU, B. "El cultivo del mejillón en Europa". Anais da Academia Brasileira de Ciências, n. 47 (Suplemento), p. 11-48, 1976.

ANGEILLO, I.F.; VIGGIANI, N.M.A.; RIZZO, L.; BIANCO, A. Food handers and foodborne diseases: knowledge, attitudes, and reported behaivor in Italy. Journal of Food Protection, v. 63, n.3, p. 381-385, 2000.

ANTONIOLLI, M.A. Vida útil do mexilhão Perna perna (L.) processado e mantido sob refrigeração. Florianópolis, 1999. 99p. Dissertação (Mestrado) Universidade Federal de Santa Catarina.

ASSOCIAÇÃO BRASILEIRA DE NORMAS TÉCNICAS. Teste de ordenação em análise sensorial - NBR 13170. São Paulo: ABNT, 1994. 45 p.

ASSOCIAÇÃO CATARINENSE DE AQÜICULTURA - ACAQ. Valores nutricionais do mexilhão Perna perna e da ostra Crassostre gigas. http://www.acaq.org.br/valores_nutricionais.htm (15 nov. 2004)

ASSOCIATION OF OFFICIAL AGRICULTURAL CHEMISTS. Official methods of analysis. 16 ed. Washington: A.O.A.C., 1995. v. 2. 1250p.

ASSUMPÇÃO, A. Estudo da viabilidade de criação de cooperativa dos produtores de mexilhões do litoral norte paulista. Piracicaba: ESALQ, Departamento Economia, Administração e Sociologia, 1999. 40 p. (Relatório CES, 629).

AYULO, A.M.R.; MACHADO, R.A.; SCUSSEL, V.M. Enterotoxigenic Escherichia coli and Staphylococcus aureus in fish and seafood from the southern region of Brazil. International Journal of Food Microbiology, v. 24, n. 1-2, p. 171178, 1994. 
BARNI, E.J.; SILVA, M.C.; ROSA, S.C.C.; PINTO, S.A. Estudo do mercado de mexilhões em três centros consumidores. São Paulo, Curitiba e Porto Alegre. Florianópolis: EPAGRI - Empresa de Pesquisa Agropecuária e Extensão Rural de Santa Catarina., 2002. 43 p.

BEAN, N. H.; GRIFFIN, P. M. Foodborne disease outbreaks in the United States, 1973-1987: pathogens, vehicles and trends. Journal of Food Protection, v.53, n.9, p. 804-817, 1990.

BEIRÃO, H.; TEIXEIRA, E.; MEINERT, E.M.; et al. Processamento e industrialização de moluscos. In: SEMINÁRIO E WORKSHOP TECNOLOGIAS PARA APROVEITAMENTO INTEGRAL DO PESCADO, Campinas, 2000. Campinas: ITAL, Centro de Tecnologia de Carnes, 2000. p.38-84.

BEIRÃO, L.H. Industrialização de mariscos e ostras. In: ENCONTRO DO AGRONEGÓCIO DA PESCA E AQUICULTURA, 1., 2002. Comunicação pessoal.

BERTULLO, V. Tecnologia de los productos y subproductos de pescados, moluscos y crustaceos. Buenos Aires: Ed. Hemisferio Sur, 1976. 370p.

BINDU, J.; GOPAL, T.K.S.; JOSEPH, A.C.; NAIR, T.S.U; JOSEPH, K.G. Effect of vacuum packaging on the shelf life of fried mussel, Perna viridis (Linnaeus) in flexible packaging material. Fishery Technology, v. 39, n.2, p. 137-141, 2002.

BORGHETTI, J.R.; OSTRENSKY, A. A cadeia produtiva da aqüicultura brasileira. In: VALENTI, W.C.; POLI, C.R.; PEREIRA, J.A.; BORGETTI, J.R. Aqüicultura no Brasil, Brasília : CNPq, 2000. p. 107-142. 
BOURGEOIS, C. M.; MESCLE, J.F.; ZUCCA, J. Microbiologia alimentaria. Zaragoza: Acribia, 1994. v. 1, 437p.

BRASIL. Ministério da Agricultura. Regulamento da Inspeção Industrial e Sanitária de Produtos de Origem Animal - RIISPOA. Brasília, 1980. $165 p$.

BRASIL. Ministério da Agricultura e do Abastecimento. Regulamentos técnicos de identidade e qualidade de leite e produtos lácteos. Ministério da Agricultura e do Abastecimento/ Secretaria de Defesa Animal/ Departamento de Inspeção de Produtos de Origem Animal/ Divisão de Normas Técnicas. Brasília, D.F. Série regulamentação técnica de identidade e qualidade de produtos de origem animal; n.2. 1997, 77p.

CAMBERO, M. I.; JARAMILLO, C. J.; ORDOÑEZ, J. A.; COBOS, A.; PEREIRALIMA, C.I.; FERNANDO, G.D.G. de. Effect of cooking conditions on the flavour compounds and composition of shrimp (Parapenaeus longirostris) broth. Zeitschrift für Lebensmitteluntersuchung und Forschun, v 206, n 5, p. 311-322, 1998.

CARDONHA, A.M.S.; CASIMIRO, A.R.S.; VIEIRA, R.H.S.F. Identificação de bactérias psicotróficas em caudas de lagosta, durante processo industrial com tripolifosfato de sódio. Higiene Alimentar, v. 8, n. 31, p. 29-34, 1994.

CARDOSO, E.S. Pescadores artesanais: natureza, território, movimento social. São Paulo, 2001. 143p. Tese (Doutorado) - Faculdade de Filosofia, Letras e Ciências Humanas, Universidade de São Paulo. 
CAVALCANTE, C.E.M. de H.; SILVA, V.L. da; SALGUEIRO, A.A. Avaliação microbiológica da água do riacho Cavouco, Recife - PE. Higiene Alimentar, v.12, n.57, p.45-49, set. /out. 1998.

CHAI, T.; PACE, J.; SCHLIMME, D.V.; LINAG, K.T. Effect of heat processing on quality of pasteurized oysters. Journal of Food Science, n. 56, p. $1294-$ 1298, 1994.

CHARM, S.E.; LEARSON, R.J.; RONSIVALLI, L.J. SCHWARTZ, M. Organoleptic technique predicts refrigeration shelf life of fish. Food Technology, v. 26, n. 7, p. 65-68, 1972.

COMPANHIA DE TECNOLOGIA DE SANEAMENTO AMBIENTAL (CETESB). Relatório de balneabilidade das praias paulistas 2002. São Paulo, 2003. 206 p.

CONTRERAS GUZMÁN, E.S. Bioquímica de pescados e derivados. Jaboticabal: FUNEP, 1994. 409p.

COOK, D.W. Microbiology of bivalves molluscan shellfish. In: WARD, D.R.; HACKNEY, C. Microbiology of marine food products. New York: Van Nostrand Reinhold, 1991. cap. 2, p.19-34.

CUNHA, D.F. da.; CUNHA, S.F.C. da. Microminerais. In: DUTRA-DEOLIVEIRA, J.E.; MARCHINI, J.S. Ciências nutricionais. São Paulo: Sarvier, 1998. cap.9, p.141-166.

DASSO, I. Qué ponemos en jurgo al degustar un alimento? La Alimentación Latinoamericana, v.33, n.229, p.34-36, 1999. 
DETHMERS, A.E. Utilizing sensory evaluation to determine product shelf life. Food Technology, v. 33, n. 9, p. 40-42, 1979.

DUTRA-DE-OLIVEIRA, J.E.; MARCHINI, J.S. Macrominerais. In: DUTRA-DEOLIVEIRA, J.E.; MARCHINI, J.S. Ciências nutricionais. São Paulo: Sarvier, 1998. cap.8, p.133-140.

ENFORS, S.O.; MOLIM, G. The influence of temperature on the growth inhibitory effect of carbon dioxide on Pseudomonas fragi e Bacillus cereus. Canadian Journal of Microbiology, v. 27, n.1, p. 15-19, 1981

ESPÍNOLA, O.; DIAS, R.C. O mexilhão como matéria-prima alimentar. ABIA/SAPRO, n. 47, p.10-30, 1980.

FANG, S.W.; CHU, S.Y.; SHIH, D.Y.C. Occurrence of Bacillus cereus in instant cereal products and their hygienic properties. Journal of Food Drug Analysis, v. 5, p. 139-144, 1997.

FAO. El Estado de los recursos pesqueros: tendencias de la producción, aprovechamiento y comercio http://www.fao.org/DOCREP/003/X8002S (20 maio 2004b).

FAO. La producción mundial de pescado, crustáceos y moluscos llegó a ... http://www.fao.org/fi/trends/worldprod99s (18 maio 2004a)

FERNÁNDEZ-ARMESTO, F. Comida: uma história. São Paulo: Record, 2004. $362 p$. 
FERREIRA, J.F.; MAGALHÃES, A.R.M. Mexilhões: biologia e cultivo. Florianópolis: Laboratório de mexilhões da Universidade Federal de Santa Catarina, 1996. 27p.

FORSYTHE, S. J. Microbiologia da segurança alimentar. Porto Alegre: Artmed, 2002. 424 p.

FRANCO B.D.G.M.; LANDGRAF, M. Microbiologia dos alimentos. São Paulo: Atheneu, 1996. 182p.

FRANCO, G.V.E. Nutrição: texto básico e tabela de composição química de alimentos. 8. ed. São Paulo. Livraria Atheneu, 2004, p. 226.

FURLAN, E.F. Vida útil dos mexilhões Perna perna cultivados no litoral norte de São Paulo: aferição dos parâmetros físico-químicos e microbiológicos. Piracicaba, 2004. 106p. Dissertação (Mestrado) - Escola Superior de Agricultura "Luiz de Queiroz", Universidade de São Paulo.

FURLAN, É.F.; GALVÃO, J.A.; SALAN, E.O.;GELLI, V.C.; PORTO, E.; OETTERER, M. Staphylococcus aureus em mexilhões cultivados na região de Ubatuba, SP. In: SIMPÓSIO LATINO AMERICANO DE CIÊNCIA DE ALIMENTOS, 5., Campinas, 2003. Resumos. Campinas: Unicamp, 2003a.

FURLAN, É.F.; GALVÃO, J.A.; SALAN, E.O.;GELLI, V.C.; PORTO, E.; OETTERER, M. Salmonella spp em mexilhões Perna perna cultivados na região de Ubatuba, SP. In: SIMPÓSIO LATINO AMERICANO DE CIÊNCIA DE ALIMENTOS, 5., Campinas, 2003. Resumos. Campinas: Unicamp, 2003b. 
FURTADO, S.M.B.; DOMINGOS, T.H.; SOARES, A.K. Determinação da composição centesimal e minerais de moluscos (Mytella falcata e Anomalocardia brasiliana) mais consumidos no estado do Rio Grande do Norte (Compact disc). In: CONGRESSO BRASILEIRO de CIÊNCIA e TECNOlOGIA de Alimentos, 16., Porto Alegre, 1998. Resumos. Porto Alegre: UFRS, 1998.

GALVÃO, J.A. Qualidade microbiológica da água de cultivo e de mexilhões Perna perna (Linnaeus, 1758) comercializados em Ubatuba, SP. São Paulo, 2004. 109p. Dissertação (Mestrado). Escola Superior de Agricultura "Luiz de Queiroz" - Universidade de São Paulo - ESALQ/USP.

GELLI, D.S. Análise microbiológica de pescado marinho. In: SEMINÁRIO SOBRE CONTROLE DE QUALIDADE NA INDÚSTRIA DE PESCADO. Santos. 1988. p. $59-62$.

GELLI, V.C. Aproveitamento de mexilhões - aspectos gerais MolluscaBivalvia. Fortaleza: Universidade Federal do Ceará, 1992. 98 p.

GELLI, V.C.; PEREIRA, R.T.L.; GIFFONI, B.B.; ALVES, M.R.P. Caracterização da mitilicultura no Litoral Norte de São Paulo. In: SEMANA NACIONAL DE OCEANOGRAFIA 11., Porto Alegre, 1998. Resumos. Porto Alegre: Editora Universitária, 1998. p.37-40.

GENIGEORGIS, C.A.; Present state of knowledge on Staphylococcal intoxication. International Journal of Food Microbiology, v. 9, p. 327-360, 1989. 
GERMANO, P.M.L.; GERMANO,M.I.S.; OLIVEIRA, C.A.F. Aspectos da qualidade do pescado de relevância em saúde pública. Higiene Alimentar, v.12, n.53, p. 30-37. jan./fev. 1998.

GERMANO, P.M.L.; OLIVEIRA, J.C.F.; GERMANO, M.I.S. O pescado como causa de toxinfeções bacterianas. Higiene Alimentar, v. 7, n. 28, p. 40-45, 1993.

GOKOGLU, N.; YERLIKAYA, P.; CENGIZ, E. Effects of cooking methods on the proximate composition and mineral contents of rainbow trout (Oncorhynchus mykiss). Food Chemistry, v. 84, p. 19-22, 2004.

GOMES, R.O.; MARENZI, A.W.C.; MANZONI, G.C. Utilização econômica do índice de condição do mexilhão Perna perna (L., 1758), no parque de mitilicultura na enseada de Armação do Itapocoroy, (2647'S-48³6'W) Penha, SC, Brasil. In: SIMPÓSIO BRASILEIRO DE AQUICULTURA, 10., Florianópolis 1998. Resumos. Florianópolis: Editora Universitária 1998. p.119.

GREENBERG, A.E.; CLESCEPS, L.S.; EATON, A.D. (Eds.) Standard methods for the examination of water and wasterwater. 18. ed. Whashington: APHA, 1992. 345p.

GUEN, S.L.; PROST, C.; DEMAIMAY, M. Evaluation of the representativeness of the odor of cooked mussel extracts and the relationship between sensory descriptions and potent odorants. Journal of Agriculture and Food Chemistry, v. 49, p. 1321-1327, 2001. 
GUILHERME, E.F.M.; SILVA, J.A.M.da; OTTO, S.S. Pseudomona aureginosa, como indicador de contaminação hídrica. Higiene Alimentar, v.14, n.76, p.43-47. set. 2000 .

GUIMARÃES, A.G. Contaminação de molusco Anomalocardia brasiliana (Gmelin, 1791), por Vibrio parahaemolyticus e Vibrio vulnificus, na região Norte da Baía de Todos os Santos - Bahia. Campinas, 2002. 120p. Tese (Doutorado) - Faculdade de Engenharia de Alimentos, Universidade de Estadual de Campinas.

HAARD, N.F. Control of chemical composition and food quality attributes of cultured fish. Food Research International. v. 1, n. 25, p. 289-307, 1992.

HAGLER, A.N.; HAGLER, L.C.S.M. Indicadores microbiológicos de qualidade sanitária. In: ROITMAM, I; TRAVASSOS, L.R.; AZEVEDO, J.L. (Ed.) Tratado de microbiologia. São Paulo: Manole, 1988. v.1. cap3. p.88-96.

HATAKKA, M.; BJÖRKROTH, K.J.; ASPLUD, K.; MÄKI-PETÄYS, N.; KORKEALA, H. Genotypes and enterotoxicity of Staphylococcus aureus isolated from the hands and nasal cavities of flight-catering employees. Journal of Food Protection, v. 11, p. 1487-1491, 2000.

HAYES, P.R. Microbiologia e higiene de los alimentos. Zaragoza: Acribia, 1993. 369p.

HENDLER, S.S. A enciclopédia de vitaminas e minerais. 8.ed. Rio de Janeiro: Campus, 1994. 576p. 
HENRIQUES, M.B. Avaliação dos bancos naturais do mexilhão Perna perna (Linnaeus, 1758) na baía de Santos, Estado de São Paulo. Rio Claro, 2001. 74p. Dissertação (Mestrado) - Centro de Estudos Ambientais, Universidade Paulista Julio Mesquita Filho.

HOFFMANN, F.L.; CRUZ, C.H.G.; VINTURIM, T.M.; FÁZIO, M.L.S. Levantamento da qualidade higiênico-sanitária de pescado comercializado na cidade de São José do Rio Preto (SP). Higiene Alimentar, v. 13, n.64, p. 45-48. 1999.

HUSS, H.H.; REILLY, A.; EMBAREK, P.K.B. Prevention and control of hazards in seafood. Food Control, v.11, p.149-156, 2000.

INTERNATIONAL COMMISSION ON MICROBIOLOGICAL SPECIFICATIONS FOR FOODS (ICMSF). Microorganismos de los alimentos. Zaragoza: Acribia, 1983. v. 1, 431 p.

INTERNATIONAL COMMISSION ON MICROBIOLOGICAL SPECIFICATIONS FOR FOODS (ICMSF). Fish and fish products. In: Microorganisms in Foods 6. Microbial Ecology of Food Commodities. London: Blackie Academic e Professional, 1998, p. 154-158.

JAKABI, M.; GELLI, D. S.; SAKUMA, H.; PAULA, A. M. R. MESQUITA, P. Avaliação da contaminação microbiológica por Salmonella spp, V. cholerae 01, coliformes totais e de origem fecal em pescados de origem marinha, analisados no período de jan/97 a jul/99. In: ENCONTRO NACIONAL DE ANALISTAS DE ALIMENTOS, 11., Recife, 2000 [Painel].

JAY, J. M. Modern food microbiology. 4 ed. NewYork: Van Nostrand Reinhold, 1992. 560 p. 
JOHNSON, K.M.; NELSON, C.L.; BUSTA, F.F Influence of temperatura on germination and growth of spores of emetic and diarrheal strains of Bacillus cereus in a broth medium and in rice. Journal of Food Science, v. 48, n. 1, p. $286-287,1983$.

JOSÉ, V.F. Bivalves e a segurança do consumidor. São Paulo, 1996. 157p. Dissertação (Mestrado). Instituto Oceanográfico, Universidade de São Paulo.

JUNEIA, V.K.; MARMER, B.S.; EBLEN, B.S. Predictive model for the combined e.ect of temperature, $\mathrm{pH}$,sodium chloride, and sodium pyrophosphate on the heat resistance of Escherichia coli O157:H7. Journal of Food Safety, v. 19, p. 147-160, 1999.

KARAKOLTSIDIS, P.A.; ZOTOS, A.; CONSTANTINIDES, S.M.; Compositon, of the commercially important mediterranean finfish, crustaceans, and molluscs. Journal of Food Composition, v. 8, p. 258-273, 1995.

KONGKACHUICHAI, R.; NAPATTHALUNG, P.; CHAROENSIRI, R. Heme and Nonheme Iron Content of Animal Products Commonly Consumed in Thailand Journal of Food Composition and Analysis, v. 15, p. 389 - 398, 2002.

KOTROLA, J.S.; CONNER, D.E.. Heat inactivation of Escherichia coli O157:H7 in turkey meat as affected by sodium chloride, sodium lactate, polyphosphate, and fat content. Journal of Food Protection, v. 60, p. 898902, 1997. 
KYRIAZI-PAPADOPOUPOU, A.; VARELTZIS, K.; BLOUKAS, J.G.; GEORGAKIS, S. Effect of smoking on quality characteristics and shelf-life of Mediterranean mussel (Mytilus galloprovincialis) meat under vacuum in chilled storage. Italian Journal of Food Science, v. 15, n. 3, p. 371-381, 2003.

LALOO, S; RAMPERSAD, F.S.; BORDE, A. la; MAHARAJ, K.; SOOKHAI, L. et al. Bacteriological quality of raw oyster in Trinidad and the attitudes, knowledge and perceptions of the public about its comsuption. International Journal of Food Microbiology, v. 54, n. 9, p. 99-107, 2000.

LANCETTE, G.A.; TATINI, S.R. Staphylococcus aureus. In: VANDERZANT, C.; SPLITTSTOESSER, D. F. Compedium of methods for the microbiological examination of foods. 3.ed. Washington: APHA, 1992. cap. 33. p. 533-550.

LANCIOTTI, R.; SINIGAGLIA, M.; GARDINI, F.; VANINI, L.; GUERZONI, M.E. Growth/no growth interfaces of Bacillus cereus, Staphylococcus aureus and Salmonella enteritidis in model systems based onwater activity, $\mathrm{pH}$, temperature and ethanol concentration. Food Microbiology, v. 18, p. 659$668,2001$.

LANDGRAF, M.; LEME, K. B. P.; GARCIA-MORENO, M. L. Occurence of emerging pathogenic Vibrio spp in seafood consumed in São Paulo city Brazil. Revista de Microbiologia, v. 27, p. 126-130. 1996.

LEDERER, J. Enciclopédia moderna de higiene alimentar. São Paulo: Manole Dois, 1991. 315p. 
LEMA, M.L.; NAVARRO, M.DEL P.; MATAIX, F.J.; VARELA, G. Influência de los procesos de coccion y desecacion a distinta temperatura sobre el valor nutritivo de la proteína del mejillon (Mytilus edulis). Archivos Latinoamericanos de Nutricion, v. 36, n. 3, p. 495-04, 1986.

LIRA, A.A.; BARROS, G.C.; LIMA, M.C.G.;MOTA, R.A. Aspectos sanitários do ambiente aquático onde são capturados moluscos bivalves para consumo no Grande Recife, PE. Higiene Alimentar, v.11, n.77, p.53-57, out 2000.

MAGALHÃES, A.R.M. Teor de proteína do mexilhão Perna perna (Linné, 1957)(Molusca - Bivalvia) em função do ciclo sexual. São Paulo, 1986. 117p. Dissertação (Mestrado). Instituto de Biociências, Universidade de São Paulo.

MANDEVILLE, S.; YAYLAYAN, V.; SIMPSON, B.K. GC/MS analysis of flavor active compounds from cooked shrimp waste. Journal of Agricultural and Food Chemistry, v. 40, p. 1275-1279, 1992.

MANDEVILLE, S.; YAYLAYAN, V.; SIMPSON, B.K.; RAMASWAMY, H. Isolation and identification of carotenoid pigments, lipids and flavor active compounds from raw commercial shrimp waste. Food Biotechnology, v. 55, p. 185-196, 1991.

MARQUES, H.L.A. Criação comercial de mexilhões. São Paulo: Nobel, 1998. $111 p$.

MARQUES, H.L.A.; PEREIRA, R.T.L. Levantamento e dimensionamento preliminares das áreas mais favoráveis para a prática da mitilicultura no litoral do município de Ubatuba, Estado de São Paulo (23, 26'S, 045 04'W).

Boletim Técnico do Instituto de Pesca, n. 13, p. 1 - 10. 1989. 
MARTINEZ-MANZANARES, E.; MORIÑIGO, M.A.; CORNAX, R., et al. Relation between classical indicators and several pathogenic microrganisms involved in shellfish-borne diseases. Journal of Food Protection, v.54, n.9, p.711$717,1991$.

MARTINS, M.T. Isolamento de Vibrio e Salmonella em moluscos bivalves e sua relação com a qualidade da água. Higiene Alimentar, v.2, n,3, set.1983.

MASCARENHAS, J. C.; SIMÕES, A. M. M.; MORAIS, S. I. M.; ALMEIDA, A. C. de et al. Isolamento do $V$. mimicus em pescado envolvido em surtos de toxinfecção alimentar na cidade de Salvador-BA. In:CONGRESSO BRASILEIRO DE MICROBIOLOGIA, 20., Salvador, 1999. Resumos. Rio de Janeiro: SBM, 1999. p.386

MAUGERI, T. L.; CACCAMO, D.; GUGLIANDOLO, C. Potentially pathogenic vibrios in brackfish waters and mussels. Journal of Applied Microbiology, v.89, n.2, p. 261-266. 2000.

MCMEEKIN, T. A.; PRESSER, K.; RATKOWSKI, D. A.; ROSS, T.; SALTER, M.; TIENUNGOON, S. Quantifying the hurdle concept by modelling the growth/no growth interface: A review. International Food Microbiology, v. 55, p. 93-98, 2000.

MEAD, P.S.; SLUTSKER, L.; DIETZ, V.; McCAIG, L.F.; SHAPIRO, C., GRIFFIN, P.M.; TAUXE, R.V. Food related illness and death in the United States. Center for Disease Control and Prevention, v. 6, n. 6, 2000. 
MEDEIROS, K.J.; TENSINI, M.; MATOS, C.H.; FACCIN, G.L.; BEIRÂO, L.H. Teor de zinco de mariscos (Perna perna) e ostras (Crassostrea gigas) da região de Florianópolis, Santa Catarina. In: CONGRESSO NACIONAL DA SOCIEDADE BRASILEIRA DE ALIMENTAÇÃO E NUTRIÇÃO, 4., São Paulo, 1996. Resumos dos trabalhos. São Paulo, 1996. p.39-44.

MEILGAARD, M.; CIVILLE, G.V.; CARR, B.T. Sensory evaluation techniques. 2 ed. Miami: CRC Press, 1991. 345p.

MENDES , E. S.; LOPES, C. A. de M.; MENDES, P. de P.; COELHO, M. I. de S. CARVALHO, E. Avaliação microbiológica de ostras consumidas na grande Refice - PE. In: CONGRESSO BRASILEIRO DE CIÊNCIA E TECNOLOGIA DE AlIMENTOS, 18. Porto Alegre, 2002. Anais. Porto Alegre: SBCTA, 2002. p. $430-434$.

NEMETZ T.G.; SHOTTS E.B. Zoonotic diseases. In: STOSKOPF, M.K. (Ed.) Fish medicine. Philadelphia: W.B. Saunders, 1992. p. 214-220.

NETTLETON, J.A. Seafood nutrition: facts, issues and marketing of nutrition in fish and shellfish. Huntington: Osprey Books. 1985. 58p

NEWELL, G. J.; MACFARLANE, J. D. Expanded tables for multiple comparison procedures in the analysis of ranked data. Journal of Food Science, v.52, n.6, p. 1721 - 1725, 1987.

NORT, E. Importância do controle físico na qualidade do pescado. In: SEMINÁRIO SOBRE CONTROLE DE QUALIDADE NA INDÚSTRIA DE PESCADO. Santos, 1988. p.135-144. 
OETTERER, M. Relatório da $1^{\mathrm{a}}$ fase do projeto de políticas públicas da FAPESP - Processo 01/12919 - 1. 2003. Diagnóstico e intervenções emergentes para viabilizar a comercialização e o beneficiamento do pescado e derivados-mexilhões, no Litoral Norte de São Paulo. 85p.

OGAWA, M.; MAIA, E.L. Manual de pesca: ciência e tecnologia do pescado. São Paulo: Varela, 1999. v.1.

OLA, J.B.; OLADIPO, A.E. Storage life of croaker (Pseudotholitus senegalensis) in ice and ambient temperature. African Journal of Biomedical Research, v. 7, n. 1, p. $13-17,2004$

OSTINI, S.; GELLI, V.C. Curso de criação de mexilhões. Ubatuba: s. ed., s/d. $45 p$.

OSTRENSKY, A.; BORGHETTI, J.R.; PEDINI, M. Situação atual da aqüicultura brasileira e mundial. In: VALENTI, W.C.; POLI, C.R.; PEREIRA, J.A.; BORGETTI, J.R. Aquicultura no Brasil. Brasília: CNPq, 2000. p. 355-381.

PÁDUA, H.B. Informações sobre coliformes totais/ fecais e alguns outros organismos indicadores em sistemas aquáticos, 2003. 20p.: http://www.pescar.com.br/helcias (10 maio 2004).

PAN, T.M.; WANG, T.K.; LEE, C.L; CHIEN, S.W.; HORNG, C.B. Food-borne disease outbreaks due to bacteria in Taiwan, 1986 to 1995 . Journal of Clinical Microbiology, v. 35, p. 1260-1262, 1997.

PAREIRA, M. L.; DO CARMO, L.S.; DOS SANTOS, E.J.; PEREIRA, J.L.; BERGDOLL, M. S. Enterotoxin $\mathrm{H}$ in staphylococcal food poisoning. Journal Food Protection, v. 59, p. 559-561, 1996. 
PEDROSA, L.F.C.; COZZOLINO, S.M.F. Composição centesimal e de minerais de mariscos crus e cozidos da cidade de Natal - RN. Ciência e Tecnologia de Alimentos, v. 21, n. 2, p. 154-157, 2001.

PENG, H.; FORD, V.; FRAMPTON, E.W.; RESTAINO, L. et al. Isolation and enumeration of Bacillus cereus fromfoods on a novel chromogenic plating médium . Food Microbiology, v. 18, p. 231-238. 2001.

PEREIRA, O.M.; GELLI, V.C.; HENRIQUES, M.B.; MACHADO, I.C.; BASTOS, A.A. Programa de desenvolvimento da criação ordenada de moluscos bivalves no Estado de São Paulo http://www.pesca.sp.gov.br/RelTec2.htm (21 ago. 2003).

PIGOTT, G.M.; TUCKER, B. Seafood: efects of technology on nutricion. New York: Marcel Dekker, 1990. 362p.

QUAYLE, D.B.; NEWKIRK, G.F. Farming Bivalve Molluscs: methods for study and development. In: SANDIFER, P.A. Advances in world aquaculture. Montreal: The World Aquaculture Society, 1989. v.1, 249p.

RAWLES, D.; FLICK, G.; PIERSON, M.; DIALLO, A.; WITTMAN, R.; CROONENBERGHS, R. Listeria monocytogenes occcurrence and growth at refrigeration temperatures in fresh blue crab (Callinectes sapidus) meat. Journal of Food Protection, v. 58, n. 11, p. 1219 - 1221. 1995.

REILY, L.A.; HACKNEY, C.R. Survival of Vibrio cholerae during cold storage in artificially contaminated seafoods. Journal of Food Science, v. 50, p. $838-$ 839, 1985. 
RODRIGUES, P. F. Caracterização sanitária de áreas de criação de moluscos bivalvos do litoral norte do Estado de São Paulo. São Paulo, 1998. 66p. Tese (Mestrado) - Instituto de Biociências, Universidade de São Paulo.

RODRIGUES-ARIZA, A.; ABRIL, N.; NAVAS, J.I.; DORADO, G.; LOPEZBAREA, J.; PUEYO, C. Metal, mutagenicity, and biochemical studies on bivalves mollucs from Spanish coasts. Environimental and Molecular Mutagenesis, v. 19, p. $112-124,1992$.

SANTOS, E. Zoologia brasílica: moluscos do Brasil. Belo Horizonte: Itatiaia, 1982. 141p.

SAS Institute. SAS user's guide: statistics (software). Version 8.0. Cary: SAS, 1999.

SCHAFFNER, D.F.; HAMDY, M.K.; TOLEDO, R.T.; TIFT, M.L. Salmonella inactivation in liquid whole egg by thermoradiation. Journal of Food Science, n. 54, p. 902-905, 1989.

SCHOELLER, N.P.; INGHAM, S.C. Comparison of the Baird-Parker agar and $3 \mathrm{M}^{\mathrm{TM}}$ PetriFilm ${ }^{\mathrm{TM}}$ rapid $\mathrm{S}$. aureus count platemethods for detection and enumeration of Staphylococcus aureus. Food Microbiology, v. 18, p. 581$587,2001$.

SCHRAMM, M.A. Caracterização e aproveitamento de mexilhões Perna perna (Linné, 1758). Porto Alegre, 1993. 54p. Monografia (Graduação) Faculdade de Engenharia de Alimentos, Universidade Federal do Rio Grande do Sul. 
SHAH K.L.; TYAGY B.C. An eye disease in silver carp, Hypophthalmichthys molitrix, held in tropical ponds, associated with the bacterium Staphylococcus aureus. Aquaculture, v. 55, p. 1-4. 1986.

SILVA JUNIOR, E.A. Manual de controle higiênico-sanitário em alimentos. São Paulo: Livraria Varela, 1995. 347p.

SILVA, J.A. Tópicos da tecnologia dos alimentos. São Paulo: Livraria Varela, 2000. 227p.

SILVA, N da; NETO, R.C.; JUNQUEIRA, V. C. A.; SILVEIRA, N.S.A. Manual de métodos de análise microbiológica da água. Campinas: ITAL, 2000. 99p.

SIMPSON, B.K. Innovative strategies for controlling fresh fish texture degradation during postharvest handling and storage. In: SHAHIDI, F.; JONES, Y.; KITTS, D.D. (Ed). Seafood safety, processing and biotechonology. Lancester: Technomic Publishing, 1997. cap. 17, p. 161180.

SKIPNES, D.; OINES, S.; ROSNES, J.T.; SKARA,T. Heat transfer in vacuum packed mussels (Mytilus edulis) during thermal processing. Journal of Aquatic Food Product Technology, v.11, n. 3/4, p. 5-21. 2002.

SKONBERG, D.I.; PERKINS, B.L. Nutrient composition of green crab (Carcinus maenus) leg meat and claw meat. Food Chemistry, v. 77, p. 401-404, 2002.

SON, N.T.; FLEET, G.H. Behavior of pathogenic bacteria in the oyster, Crassostrea commercialis, during depuration, re-laying, and storage. Applied and Environmental Microbiology, v. 40, n. 6, p. $994-1002.1980$. 
STONE, H.; SIDEL, J. Sensory evalution practices. 2 ed. New York: Academic Press, 1993. 338p.

STREIT, D.P.; LUPCHINSKI, E.;MOREIRA, H.L.M.; RIBEIRO, R.P.; MORAES, G.V.; VARGAS, L.D. Perspectivas atuais da aquicultura marinha no Brasil. Maringá: IAPAR, n.4, p. 80 - 82, 2002.

SUBASINGHE, R.P.; BUENO, P.; PHILLIPS, M.J.; BRIAN, S.A. (Ed.) Aquaculture in the Third Millenium. In: TECHNICAL PROCEEDINS OF THE CONFERENCE ON AQUACULTURE IN THE THIRD MILLENIUM. Bangkok: NACA; Rome: FAO, 2001. 471p.

TAVARES, M.; SABRIA, A.; BACETTI, L.B; SILVA, A.; OLIVEIRA, R. Métodos sensoriais, físicos e químicos para análise de pescado. In: SEMINÁRIO SOBRE CONTROLE DE QUALIDADE NA INDÚSTRIA DE PESCADO. Santos, 1988. p.117 -134.

VANDERZANT, C.; SPLITTSTOESSER, D. F. Compendium of methods for the microbiological examination of foods. 3.ed. Washington: American Public Health Association, 1992. cap. 25, 1219p.

WATTS, B. M.; YLIMAKI, G. L.; JEFERRY, L. E.; ELÍAS, L. G. Métodos sensoriales básicos para la elevación de alimentos. Ottawa: CIID, 1992. $170 p$.

WOOD, P.C. Manual de higiene de los mariscos. Zaragoza: Acribia, 1979. 79p.

YASUHARA, A.; MORITA, M. Identification of volatile organic components in mussel. Chemosphere, v. 16, n. 10-12, p. 2559-2565, 1987. 
APÊNDICE 
1. Número Mais Provável (NMP) - para várias combinações de resultados positivos, quando três tubos são utilizados por diluições (inoculações de 1,0, 0,1 e $0,01 \mathrm{~g}$ ou $\mathrm{mL}$ da amostra).

\begin{tabular}{|c|c|c|c|c|c|c|c|}
\hline \multicolumn{9}{|c|}{ Combinação de tubos positivos } & \multicolumn{4}{c|}{ Combinação de tubos positivos } \\
\hline $1,0 \mathrm{~g}-\mathrm{mL}$ & $0,1 \mathrm{~g}-\mathrm{mL}$ & $0,01 \mathrm{~g}-\mathrm{mL}$ & $\mathrm{NMP}$ & $1,0 \mathrm{~g}-\mathrm{mL}$ & $0,1 \mathrm{~g}-\mathrm{mL}$ & $0,01 \mathrm{~g}-\mathrm{mL}$ & $\mathrm{NMP}$ \\
\hline 0 & 0 & 0 & $<0,3$ & 2 & 0 & 0 & 0,91 \\
\hline 0 & 0 & 1 & 0,3 & 2 & 0 & 1 & 1,4 \\
\hline 0 & 0 & 2 & 0,6 & 2 & 0 & 2 & 2,0 \\
\hline 0 & 0 & 3 & 0,9 & 2 & 0 & 3 & 2,6 \\
\hline 0 & 1 & 0 & 0,3 & 2 & 1 & 0 & 1,5 \\
\hline 0 & 1 & 1 & 0,61 & 2 & 1 & 1 & 2,0 \\
\hline 0 & 1 & 2 & 0,92 & 2 & 1 & 2 & 2,7 \\
\hline 0 & 1 & 3 & 1,2 & 2 & 1 & 3 & 3,4 \\
\hline 0 & 2 & 0 & 0,62 & 2 & 2 & 0 & 2,1 \\
\hline 0 & 2 & 1 & 0,93 & 2 & 2 & 1 & 2,8 \\
\hline 0 & 2 & 2 & 1,2 & 2 & 2 & 2 & 3,5 \\
\hline 0 & 2 & 3 & 1,6 & 2 & 2 & 3 & 4,2 \\
\hline 0 & 3 & 0 & 0,94 & 2 & 3 & 0 & 2,9 \\
\hline 0 & 3 & 1 & 1,3 & 2 & 3 & 1 & 3,6 \\
\hline 0 & 3 & 2 & 1,6 & 2 & 3 & 2 & 4,4 \\
\hline 0 & 3 & 3 & 1,9 & 2 & 3 & 3 & 5,3 \\
\hline 1 & 0 & 0 & 0,36 & 3 & 0 & 0 & 2,3 \\
\hline 1 & 0 & 1 & 0,72 & 3 & 0 & 1 & 3,9 \\
\hline 1 & 0 & 2 & 1,1 & 3 & 0 & 2 & 6,4 \\
\hline 1 & 0 & 3 & 1,5 & 3 & 0 & 3 & 9,5 \\
\hline 1 & 1 & 0 & 0,73 & 3 & 1 & 0 & 4,3 \\
\hline 1 & 1 & 1 & 1,1 & 3 & 1 & 1 & 7,5 \\
\hline 1 & 1 & 2 & 1,5 & 3 & 1 & 2 & 12 \\
\hline 1 & 1 & 3 & 1,9 & 3 & 1 & 3 & 16 \\
\hline 1 & 2 & 0 & 1,1 & 3 & 2 & 0 & 9,3 \\
\hline 1 & 2 & 1 & 1,5 & 3 & 2 & 1 & 15 \\
\hline 1 & 2 & 2 & 2,0 & 3 & 2 & 2 & 21 \\
\hline 1 & 2 & 3 & 2,4 & 3 & 2 & 3 & 29 \\
\hline 1 & 3 & 0 & 1,6 & 3 & 3 & 0 & 24 \\
\hline 1 & 3 & 1 & 2,0 & 3 & 3 & 1 & 46 \\
\hline 1 & 3 & 2 & 2,4 & 3 & 3 & 2 & 110 \\
\hline 1 & 3 & 3 & 2,9 & 3 & 3 & 3 & $>110$ \\
\hline
\end{tabular}


2. Teste de ordenação - Diferença crítica entre os totais das somas de ordenação (Newell e MacFarlene) - Para nível de significância de 5\%

\begin{tabular}{|c|c|c|c|c|c|c|c|c|c|c|}
\hline \multirow{2}{*}{$\begin{array}{c}\mathrm{N}^{\circ} \text { de } \\
\text { Respostas }\end{array}$} & \multicolumn{10}{|c|}{$\mathrm{N}^{0}$ de amostras } \\
\hline & 3 & 4 & 5 & 6 & 7 & 8 & 9 & 10 & 11 & 12 \\
\hline 3 & 6 & 8 & 11 & 13 & 15 & 18 & 20 & 23 & 25 & 28 \\
\hline 4 & 7 & 10 & 13 & 15 & 18 & 21 & 24 & 27 & 30 & 33 \\
\hline 5 & 8 & 11 & 14 & 17 & 21 & 24 & 27 & 30 & 34 & 37 \\
\hline 6 & 9 & 12 & 15 & 19 & 22 & 26 & 30 & 34 & 37 & 42 \\
\hline 7 & 10 & 13 & 17 & 20 & 24 & 28 & 32 & 36 & 40 & 44 \\
\hline 8 & 10 & 14 & 18 & 22 & 26 & 30 & 34 & 39 & 43 & 47 \\
\hline 9 & 10 & 15 & 19 & 23 & 27 & 32 & 36 & 41 & 46 & 50 \\
\hline 10 & 11 & 15 & 20 & 24 & 29 & 34 & 38 & 43 & 48 & 53 \\
\hline 11 & 11 & 16 & 21 & 26 & 30 & 35 & 40 & 45 & 51 & 56 \\
\hline 12 & 12 & 17 & 22 & 27 & 32 & 37 & 42 & 48 & 53 & 58 \\
\hline 13 & 12 & 18 & 23 & 28 & 33 & 39 & 44 & 50 & 55 & 61 \\
\hline 14 & 13 & 18 & 24 & 29 & 34 & 40 & 46 & 52 & 57 & 63 \\
\hline 15 & 13 & 19 & 24 & 30 & 36 & 42 & 47 & 53 & 59 & 66 \\
\hline 16 & 13 & 19 & 25 & 31 & 37 & 42 & 49 & 55 & 61 & 67 \\
\hline 17 & 14 & 20 & 26 & 32 & 38 & 44 & 50 & 56 & 63 & 69 \\
\hline 18 & 15 & 20 & 26 & 32 & 39 & 45 & 51 & 58 & 65 & 71 \\
\hline 19 & 15 & 21 & 27 & 33 & 40 & 46 & 53 & 60 & 66 & 73 \\
\hline 20 & 15 & 21 & 28 & 34 & 41 & 47 & 54 & 61 & 69 & 75 \\
\hline 21 & 16 & 22 & 28 & 35 & 42 & 49 & 56 & 63 & 70 & 77 \\
\hline 22 & 16 & 22 & 29 & 36 & 43 & 50 & 57 & 64 & 71 & 79 \\
\hline 23 & 16 & 23 & 30 & 37 & 44 & 51 & 58 & 65 & 73 & 80 \\
\hline 24 & 17 & 23 & 30 & 37 & 45 & 52 & 59 & 67 & 74 & 82 \\
\hline 25 & 17 & 24 & 31 & 38 & 46 & 53 & 61 & 68 & 76 & 84 \\
\hline 26 & 17 & 24 & 32 & 39 & 46 & 54 & 62 & 70 & 77 & 85 \\
\hline 27 & 18 & 25 & 32 & 40 & 47 & 55 & 63 & 71 & 79 & 87 \\
\hline 28 & 18 & 25 & 33 & 40 & 48 & 56 & 64 & 72 & 80 & 89 \\
\hline 29 & 18 & 26 & 33 & 41 & 49 & 57 & 65 & 73 & 82 & 90 \\
\hline 30 & 19 & 26 & 34 & 42 & 50 & 58 & 66 & 75 & 83 & 92 \\
\hline 31 & 19 & 27 & 34 & 42 & 51 & 59 & 67 & 76 & 85 & 93 \\
\hline 32 & 19 & 27 & 35 & 43 & 51 & 60 & 68 & 77 & 86 & 95 \\
\hline 33 & 20 & 27 & 36 & 44 & 52 & 61 & 70 & 78 & 87 & 96 \\
\hline 34 & 20 & 28 & 36 & 44 & 53 & 62 & 71 & 79 & 89 & 98 \\
\hline 35 & 20 & 28 & 37 & 45 & 54 & 63 & 72 & 81 & 90 & 99 \\
\hline 36 & 20 & 29 & 37 & 46 & 55 & 63 & 73 & 82 & 91 & 100 \\
\hline 37 & 21 & 29 & 38 & 46 & 55 & 64 & 74 & 83 & 92 & 102 \\
\hline 38 & 21 & 29 & 38 & 47 & 56 & 65 & 75 & 84 & 94 & 103 \\
\hline 39 & 21 & 30 & 39 & 48 & 57 & 66 & 76 & 85 & 95 & 105 \\
\hline 40 & 21 & 30 & 39 & 48 & 57 & 67 & 76 & 86 & 96 & 106 \\
\hline 41 & 22 & 31 & 40 & 49 & 58 & 68 & 77 & 87 & 97 & 107 \\
\hline 42 & 22 & 31 & 40 & 49 & 59 & 69 & 78 & 88 & 98 & 109 \\
\hline 43 & 22 & 31 & 41 & 50 & 60 & 69 & 79 & 89 & 99 & 110 \\
\hline 44 & 22 & 32 & 41 & 51 & 60 & 70 & 80 & 90 & 101 & 111 \\
\hline 45 & 23 & 32 & 41 & 51 & 61 & 71 & 81 & 91 & 102 & 112 \\
\hline 46 & 23 & 32 & 42 & 52 & 62 & 72 & 82 & 92 & 103 & 114 \\
\hline 47 & 23 & 33 & 42 & 52 & 62 & 72 & 83 & 93 & 104 & 115 \\
\hline 48 & 23 & 33 & 43 & 53 & 63 & 73 & 84 & 94 & 105 & 116 \\
\hline 49 & 24 & 33 & 43 & 53 & 64 & 74 & 85 & 95 & 106 & 117 \\
\hline 50 & 24 & 34 & 44 & 54 & 64 & 75 & 85 & 96 & 107 & 118 \\
\hline 55 & 25 & 35 & 46 & 56 & 67 & 78 & 90 & 101 & 112 & 124 \\
\hline 60 & 26 & 37 & 48 & 59 & 70 & 82 & 94 & 105 & 117 & 130 \\
\hline 65 & 27 & 38 & 50 & 61 & 73 & 85 & 97 & 110 & 122 & 135 \\
\hline 70 & 28 & 40 & 52 & 64 & 76 & 88 & 101 & 114 & 127 & 140 \\
\hline 75 & 29 & 41 & 53 & 66 & 79 & 91 & 105 & 118 & 131 & 145 \\
\hline 80 & 30 & 42 & 55 & 68 & 81 & 94 & 108 & 122 & 136 & 150 \\
\hline 85 & 31 & 44 & 57 & 70 & 84 & 97 & 111 & 126 & 140 & 154 \\
\hline 90 & 32 & 45 & 58 & 72 & 56 & 100 & 114 & 129 & 144 & 159 \\
\hline 95 & 33 & 46 & 60 & 74 & 88 & 103 & 118 & 133 & 148 & 163 \\
\hline 100 & 34 & 47 & 61 & 76 & 91 & 105 & 121 & 136 & 151 & 167 \\
\hline
\end{tabular}

Fonte: Newell e Mac Farlane (1987) 
2. Teste de ordenação - Diferença crítica entre os totais das somas de ordenação (Newell e MacFarlene) - Para nível de significância de 5\%

\begin{tabular}{|c|c|c|c|c|c|c|c|c|c|c|}
\hline \multirow{2}{*}{$\begin{array}{c}\mathrm{N}^{\circ} \text { de } \\
\text { Respostas }\end{array}$} & \multicolumn{10}{|c|}{$\mathrm{N}^{0}$ de amostras } \\
\hline & 3 & 4 & 5 & 6 & 7 & 8 & 9 & 10 & 11 & 12 \\
\hline 3 & 6 & 8 & 11 & 13 & 15 & 18 & 20 & 23 & 25 & 28 \\
\hline 4 & 7 & 10 & 13 & 15 & 18 & 21 & 24 & 27 & 30 & 33 \\
\hline 5 & 8 & 11 & 14 & 17 & 21 & 24 & 27 & 30 & 34 & 37 \\
\hline 6 & 9 & 12 & 15 & 19 & 22 & 26 & 30 & 34 & 37 & 42 \\
\hline 7 & 10 & 13 & 17 & 20 & 24 & 28 & 32 & 36 & 40 & 44 \\
\hline 8 & 10 & 14 & 18 & 22 & 26 & 30 & 34 & 39 & 43 & 47 \\
\hline 9 & 10 & 15 & 19 & 23 & 27 & 32 & 36 & 41 & 46 & 50 \\
\hline 10 & 11 & 15 & 20 & 24 & 29 & 34 & 38 & 43 & 48 & 53 \\
\hline 11 & 11 & 16 & 21 & 26 & 30 & 35 & 40 & 45 & 51 & 56 \\
\hline 12 & 12 & 17 & 22 & 27 & 32 & 37 & 42 & 48 & 53 & 58 \\
\hline 13 & 12 & 18 & 23 & 28 & 33 & 39 & 44 & 50 & 55 & 61 \\
\hline 14 & 13 & 18 & 24 & 29 & 34 & 40 & 46 & 52 & 57 & 63 \\
\hline 15 & 13 & 19 & 24 & 30 & 36 & 42 & 47 & 53 & 59 & 66 \\
\hline 16 & 13 & 19 & 25 & 31 & 37 & 42 & 49 & 55 & 61 & 67 \\
\hline 17 & 14 & 20 & 26 & 32 & 38 & 44 & 50 & 56 & 63 & 69 \\
\hline 18 & 15 & 20 & 26 & 32 & 39 & 45 & 51 & 58 & 65 & 71 \\
\hline 19 & 15 & 21 & 27 & 33 & 40 & 46 & 53 & 60 & 66 & 73 \\
\hline 20 & 15 & 21 & 28 & 34 & 41 & 47 & 54 & 61 & 69 & 75 \\
\hline 21 & 16 & 22 & 28 & 35 & 42 & 49 & 56 & 63 & 70 & 77 \\
\hline 22 & 16 & 22 & 29 & 36 & 43 & 50 & 57 & 64 & 71 & 79 \\
\hline 23 & 16 & 23 & 30 & 37 & 44 & 51 & 58 & 65 & 73 & 80 \\
\hline 24 & 17 & 23 & 30 & 37 & 45 & 52 & 59 & 67 & 74 & 82 \\
\hline 25 & 17 & 24 & 31 & 38 & 46 & 53 & 61 & 68 & 76 & 84 \\
\hline 26 & 17 & 24 & 32 & 39 & 46 & 54 & 62 & 70 & 77 & 85 \\
\hline 27 & 18 & 25 & 32 & 40 & 47 & 55 & 63 & 71 & 79 & 87 \\
\hline 28 & 18 & 25 & 33 & 40 & 48 & 56 & 64 & 72 & 80 & 89 \\
\hline 29 & 18 & 26 & 33 & 41 & 49 & 57 & 65 & 73 & 82 & 90 \\
\hline 30 & 19 & 26 & 34 & 42 & 50 & 58 & 66 & 75 & 83 & 92 \\
\hline 31 & 19 & 27 & 34 & 42 & 51 & 59 & 67 & 76 & 85 & 93 \\
\hline 32 & 19 & 27 & 35 & 43 & 51 & 60 & 68 & 77 & 86 & 95 \\
\hline 33 & 20 & 27 & 36 & 44 & 52 & 61 & 70 & 78 & 87 & 96 \\
\hline 34 & 20 & 28 & 36 & 44 & 53 & 62 & 71 & 79 & 89 & 98 \\
\hline 35 & 20 & 28 & 37 & 45 & 54 & 63 & 72 & 81 & 90 & 99 \\
\hline 36 & 20 & 29 & 37 & 46 & 55 & 63 & 73 & 82 & 91 & 100 \\
\hline 37 & 21 & 29 & 38 & 46 & 55 & 64 & 74 & 83 & 92 & 102 \\
\hline 38 & 21 & 29 & 38 & 47 & 56 & 65 & 75 & 84 & 94 & 103 \\
\hline 39 & 21 & 30 & 39 & 48 & 57 & 66 & 76 & 85 & 95 & 105 \\
\hline 40 & 21 & 30 & 39 & 48 & 57 & 67 & 76 & 86 & 96 & 106 \\
\hline 41 & 22 & 31 & 40 & 49 & 58 & 68 & 77 & 87 & 97 & 107 \\
\hline 42 & 22 & 31 & 40 & 49 & 59 & 69 & 78 & 88 & 98 & 109 \\
\hline 43 & 22 & 31 & 41 & 50 & 60 & 69 & 79 & 89 & 99 & 110 \\
\hline 44 & 22 & 32 & 41 & 51 & 60 & 70 & 80 & 90 & 101 & 111 \\
\hline 45 & 23 & 32 & 41 & 51 & 61 & 71 & 81 & 91 & 102 & 112 \\
\hline 46 & 23 & 32 & 42 & 52 & 62 & 72 & 82 & 92 & 103 & 114 \\
\hline 47 & 23 & 33 & 42 & 52 & 62 & 72 & 83 & 93 & 104 & 115 \\
\hline 48 & 23 & 33 & 43 & 53 & 63 & 73 & 84 & 94 & 105 & 116 \\
\hline 49 & 24 & 33 & 43 & 53 & 64 & 74 & 85 & 95 & 106 & 117 \\
\hline 50 & 24 & 34 & 44 & 54 & 64 & 75 & 85 & 96 & 107 & 118 \\
\hline 55 & 25 & 35 & 46 & 56 & 67 & 78 & 90 & 101 & 112 & 124 \\
\hline 60 & 26 & 37 & 48 & 59 & 70 & 82 & 94 & 105 & 117 & 130 \\
\hline 65 & 27 & 38 & 50 & 61 & 73 & 85 & 97 & 110 & 122 & 135 \\
\hline 70 & 28 & 40 & 52 & 64 & 76 & 88 & 101 & 114 & 127 & 140 \\
\hline 75 & 29 & 41 & 53 & 66 & 79 & 91 & 105 & 118 & 131 & 145 \\
\hline 80 & 30 & 42 & 55 & 68 & 81 & 94 & 108 & 122 & 136 & 150 \\
\hline 85 & 31 & 44 & 57 & 70 & 84 & 97 & 111 & 126 & 140 & 154 \\
\hline 90 & 32 & 45 & 58 & 72 & 56 & 100 & 114 & 129 & 144 & 159 \\
\hline 95 & 33 & 46 & 60 & 74 & 88 & 103 & 118 & 133 & 148 & 163 \\
\hline 100 & 34 & 47 & 61 & 76 & 91 & 105 & 121 & 136 & 151 & 167 \\
\hline
\end{tabular}

Fonte: Newell e Mac Farlane (1987) 